\title{
Valorisation of surplus food in the French retail sector: Environmental and economic
} impacts

\author{
Albizzati, Paola Federica; Tonini, Davide; Chammard, Charlotte Boyer; Astrup, Thomas Fruergaard
}

Published in:

Waste Management

Link to article, DOI:

10.1016/j.wasman.2019.04.034

Publication date:

2019

Document Version

Peer reviewed version

Link back to DTU Orbit

Citation (APA):

Albizzati, P. F., Tonini, D., Chammard, C. B., \& Astrup, T. F. (2019). Valorisation of surplus food in the French retail sector: Environmental and economic impacts. Waste Management, 90, 141-151.

https://doi.org/10.1016/j.wasman.2019.04.034

\section{General rights}

Copyright and moral rights for the publications made accessible in the public portal are retained by the authors and/or other copyright owners and it is a condition of accessing publications that users recognise and abide by the legal requirements associated with these rights.

- Users may download and print one copy of any publication from the public portal for the purpose of private study or research.

- You may not further distribute the material or use it for any profit-making activity or commercial gain

- You may freely distribute the URL identifying the publication in the public portal 


\title{
Valorisation of surplus food in the French retail sector: Environmental and economic
}

\author{
impacts
}

Paola Federica Albizzati ${ }^{1}$, Davide Tonini ${ }^{2}$, Charlotte Boyer Chammard ${ }^{3}$, Thomas

Fruergaard Astrup ${ }^{1}$

(1)
${ }^{1}$ Technical University of Denmark, Department of Environmental Engineering, Bygninstorvet 113, 2800 Lyngby, Denmark ${ }^{2}$ Joint Research Centre of the European Commission, Edificio Expo, Inca Garcilaso 3, 41092 Seville, Spain
${ }^{3}$ PHENIX, 16 rue Darcet, 75017 Paris, France

\section{Abstract}

The retail sector, generating large amounts of food waste in a limited and well-defined number of locations, represents a unique opportunity for the implementation of waste minimisation policies targeting food waste and surplus food. France has introduced policy measures forcing retailers to prioritise the redistribution of surplus food to charity (donation) and/or diversion to animal feed. To evaluate the environmental benefits from such initiatives,

2 this study provides a bottom-up consequential life cycle assessment of surplus food management at twenty retail outlets in France. A cradle-to-grave assessment was performed, 
24 including land-use changes, and the impacts were evaluated for ten impact categories. Four 25 scenarios were considered, using monthly data on waste flows and management. Alongside 26 assessing the current management (i.e. redistribution and/or use of surplus food for animal

27 feed with anaerobic digestion and incineration of residual streams), three additional scenarios 28 were evaluated: i) prevention (used as benchmark), ii) anaerobic digestion and iii) 29 incineration. The results demonstrated that redistribution leads to substantial environmental 30 savings when accounting for all potentially induced benefits, second only to prevention but

31 nevertheless of similar magnitude. Neither anaerobic digestion nor incineration can compete

32 environmentally with redistribution and use as animal feed, especially in a low-carbon energy

33 system. A cost analysis, including tax credits implemented in the French regulation, 34 demonstrated that retailers donating high-value products also achieved lower costs and 35 higher environmental savings overall. The results clearly suggest that similar initiatives 36 should be encouraged, and the study offers a consistent basis for evaluating similar initiatives 37 also for other countries.

39 Keywords: food waste; LCA; donation; waste hierarchy; prevention; redistribution 


\section{Introduction}

41 To tackle the food waste problem, the European Union (EU) engaged in meeting Sustainable

42 Development Goal (SDG) \#12 (United Nations, 2015), which, among other objectives, aims

43 to reduce food losses in the production and supply sectors as well as to halve food waste per

44 capita by 2030, from both households and retailers (European Commission, 2017a).

45 Although the retail sector is estimated to be responsible, on average, for only $5 \%$ of EU food

46 waste (most of which is instead generated by production and households; Stenmark et al.,

47 2016), it nevertheless is of key importance for food waste minimisation. Retail outlets

48 represent collection points for large amounts of food in a limited and well-defined number

49 of locations, thereby facilitating the implementation of effective policies and initiatives by

50 connecting two sectors that would otherwise be separated, namely consumers and producers

51 (Eriksson, 2015; Scholz et al., 2015). Initiatives implemented at this stage may thereby

52 induce benefits both upstream and downstream the supply chain, in addition to the retail

53 sector per se (Schönberger et al., 2013). While food waste prevention and the redistribution

54 of surplus food (i.e. food that is suitable for human consumption but it is not marketable for

55 several reasons (European Union, 2017)) should be prioritised, e.g. according to the Waste

56 Framework Directive (European Parliament and Council, 2008), very few attempts have been

57 made in the literature to assess systematically the environmental and economic benefits of

58 such initiatives in the retail sector.

59 While very few European countries have yet implemented regulations addressing 60 surplus food from retail outlets, France represents a prominent example by putting into force 61 a specific legislation in 2016, law no. 2016-138 (Legifrance, 2016), with the aim of reducing 62 food waste generation at the retail sector. In 2016, French food waste corresponded to 10 
63 million tonnes, or 16 billion euros' worth, with $14 \%$ of the losses originating from the retail

64 sector (Ministère de la Transition Écologique et Solidaire, 2017b). The French law requires

65 all retail units larger than $400 \mathrm{~m}^{2}$ to handle surplus food according to the waste hierarchy

66 (Ministère de la Transition Écologique et Solidaire, 2017b), which means that whenever food

67 is still suitable and safe for human consumption, conforming to the guidelines provided by

68 European Commission (2010) and European Commission (2017b), it should be redistributed

69 to charity organisations (European Federation of Food Banks et al., 2016; Mourad, 2015). If

70 the surplus food is still safe but not edible for humans, it should be used as animal feed, and

71 finally, if the food is suitable neither for human nor for animal consumption, then the food

72 products should be sent to anaerobic digestion or composting (Mourad, 2015). Retailers may

73 benefit from the new regulation by receiving a $60 \%$ tax credit corresponding to the economic

74 value of the redistributed food, including both the stock value of the goods, their transport

75 and storage (Mourad, 2015). The initiative is expected to have benefits for both the

76 environment and economy, but food redistribution may also have positive social effects by,

77 for example, increasing access to food for people with lower incomes (Mourad, 2015),

78 improving the nutritional intake of people in need (Scherhaufer et al., 2015), integrating

79 marginalised social groups (Vittuari et al., 2017), and involving different stakeholders that

80 felt satisfied about making a difference in their local communities (Mirosa et al., 2016).

81 Furthermore, tax credit policies are expected to lead to establishing new companies related

82 to the organisation and management of food waste and redistribution programmes (Sud

83 Ouest, 2017). With relatively few wide scale implementations of food waste prevention and

84 food redistribution initiatives, so far no consistent comparison of the variability in 
85 environmental performance of individual retail outlets, and thereby the overall potential for 86 contributing to environmental savings, have been provided.

87 Previous studies of surplus food generated by the retail sector have focused on 88 techniques to improve its management, typically applying the life cycle assessment (LCA) methodology. However, a large majority of literature studies focus on the lower levels of the 90 waste hierarchy, i.e. end-of-life treatments such as anaerobic digestion, composting, 91 incineration and landfilling (e.g. Bernstad et al., 2013; Buratti et al., 2015; Cristóbal et al., 92 2016). Two studies, Brancoli et al. (2017) and Vandermeersch et al. (2014), investigated the 93 effects of diverting surplus food to animal feed, considering as a case study a single Swedish 94 retail outlet and the Belgian retail sector, respectively. Both studies concluded that the largest 95 savings can be obtained if bread products are removed from their packaging and the main waste stream, and then used to substitute conventional animal feed (e.g. wheat) instead of 97 anaerobic digestion. While prevention has been addressed in several LCA studies (e.g. 98 Martinez-Sanchez et al., 2016; Oldfield et al., 2016; Tonini et al., 2018), highlighting 99 significant environmental benefits under the condition that indirect (rebound) effects are 100 minimised, so far few LCA studies have focused on redistribution. Among these, Eriksson et 101 al. (2015) and Eriksson \& Spångberg (2017) analysed the carbon footprint of the food waste 102 management systems of retail outlets in Uppsala (Sweden) and Växjö (Sweden), 103 respectively, in terms of redistribution and/or conversion of surplus food. Overall, the 104 findings indicated that following the waste hierarchy for surplus food management resulted 105 in the largest environmental benefits, with prevention followed by redistribution and 106 conversion to be prioritised. While these studies address retailers and the implementation of 107 redistribution initiatives, they do not i) consider the actual properties and distribution of 
108 individual food waste materials, ii) include land-use changes (LUCs) related to food 109 production and substitution, iii) assess environmental impacts over a wide range of impact 110 categories, or iv) address the economic aspects. Ignoring these aspects may lead to biased 111 conclusions (Tonini et al., 2018).

112 Using data from twenty French retail outlets that have implemented surplus food 113 redistribution and diversion to animal feed, this study builds on existing literature in the field 114 and contributes further by: i) systematically assessing the environmental benefits associated 115 with surplus food management as implemented in selected retailers in France, and ii) 116 quantifying the associated economic implications for retailers.. The environmental 117 performance of each retailer is compared against two benchmarks: a) the maximum level of 118 prevention (i.e. assuming $100 \%$ prevention of surplus food) and b) the business-as-usual 119 alternative management of such surplus food for the selected retailers, prior to enforcing law 120 no. 2016-138, involving typically anaerobic digestion and incineration. It should be borne in 121 mind that, while French food banking and donations exist since long time, a systematic and 122 dedicated management of the surplus food was not common practice and business-as-usual 123 practices typically involved biological treatment and/or incineration (Garot, 2015). This was

124 the case for the retailers selected. The study involves state-of-the-art LCA modelling of 125 individual food waste material fractions over a wide range of impact categories, and it also 126 accounts for LUCs. 
130 According to European Commission (2017b), surplus food is food and beverages that have

131 not been sold or are not marketable but are still suitable for human consumption. Surplus

132 food can either be redistributed or used as animal feed. These applications have to be 133 compliant with the EU guidelines on food donations and use-as-feed (European Commission, 134 2009; European Commission, 2017b). Redistribution is then defined by the European 135 Commission (2017a) as "a process whereby surplus food that might otherwise be wasted is 136 recovered, collected and provided to people, in particular to those in need". Redistribution of 137 food can occur either via direct donations from donor to charities, or via food banks that store 138 and distribute the donated food to end users, e.g. charities (Hanssen et al., 2014). The 139 regulations concerning and influencing food redistribution are described in Appendix $\mathrm{H}$ in 140 the Supporting Information (SI). In respect to food waste, while acknowledging that other 141 definitions are available in the literature, we define it in this study as the share (or the totality, 142 when it applies) of surplus food that is neither redistributed nor used as animal feed, but it is 143 instead sent to the waste management in place, e.g. incineration.

\subsection{The case of France}

146 Amongst the EU Member States, France is recognised as a frontrunner in respect to food 147 redistribution (Deloitte, 2014). To overcome the barriers highlighted in Appendix H (SI), 148 France has implemented regulations at national level to ease the redistribution of surplus

149 food. In respect to responsibility and traceability, France has implemented a transfer slip, 150 which concerns the state (i.e. core temperature, use by/best before date) of the food product 151 when donated and is co-signed by the food donor and the receiving organisation (e.g. charity) 152 (Deloitte, 2014). Regarding liability, food donors and receiving organisations subscribe to 
153 liability insurance and sign a partnership agreement (Deloitte, 2014). To implement the Food 154 Hygiene Package, the French Federation of Food Banks outlined a best practice guide to 155 help food donors and receiving organisations (Deloitte, 2014). To further support 156 redistribution France implemented a corporate tax incentive. As described earlier, this 157 establishes that food donors can benefit from a tax credit of $60 \%$ on the monetary value of 158 the food redistributed (Mourad, 2015).

\subsection{Scope and functional unit}

161 The functional unit of the study is the management of 1 tonne of surplus food, including 162 associated packaging, as generated by the retail sector in France (ca. $0.98 \mathrm{t}$ is food and 0.02 $163 \mathrm{t}$ is packaging). This, depending on the management of the retailer, may be partly 164 redistributed or sent for use-as-feed, and partly become food waste.

165 The study is a cradle-to-grave LCA, encompassing the entire life cycle of the surplus 166 food generated at the retail outlets. This included transport, redistribution of surplus food, 167 reuse of the surplus food as animal feed, and other treatment pathways for the waste. When 168 assessing the prevention scenario (used as benchmark), the upstream processes prior to the 169 production of surplus food were accounted for, from production of the food and associated 170 LUCs, to distribution (i.e. packaging production, transport and storage) to ensure system 171 equivalence across scenarios. The assessment was performed in accordance with the ISO 172 standards for LCA (ISO, 2006a, b), and a consequential approach was applied (Weidema, 173 2003; Weidema et al., 2009). The geographic scope of the study was France. The temporal 174 perspective covered current retailers' management practices as well as those prior to the 175 implementation of advanced management for surplus food. The consequential database 
176 provided by Ecoinvent v3.3 was used to model the life cycle impact assessment (Wernet et

177 al., 2016), which was performed for ten impact categories, namely Global Warming (Forster

178 et al., 2007), Terrestrial Acidification (Seppälä et al., 2006), Photochemical Ozone Formation

179 (van Zelm et al., 2008), Particulate Matter (van Zelm et al., 2008), Aquatic Eutrophication

180 Nitrogen (Struijs et al., 2009), Aquatic Eutrophication Phosphorous (Goedkoop et al., 2009),

181 Human Toxicity, cancer(Rosenbaum et al., 2011), Ecotoxicity (Rosenbaum et al., 2011),

182 Fossil Resource Depletion (van Oers et al., 2002) and Water Depletion (Goedkoop et al.,

183 2009). Environmental exchanges were modelled by assuming a time horizon of 100 years.

184 With respect to Global Warming, the uptake/release of biogenic $\mathrm{CO}_{2}$ from the food was

185 assigned a characterisation factor equal to 0 , while the eventually sequestered biogenic $\mathrm{CO}_{2}$

186 (within the 100-year time horizon) was assigned a factor equal to -1 , following common

187 practice for short-rotation biomass. The assessment was performed with the EASETECH

188 LCA tool (Clavreul et al., 2014).

189

$190 \quad 2.4$ Description of the scenarios and system boundaries

191 The scenarios investigated were: Scenario I (CM), representing the current management of 192 surplus food, Scenario II (AD), where surplus food is sent to anaerobic digestion (preceded 193 by pre-treatment), Scenario III (I), where surplus food is sent to incineration, and Scenario $194 I V(P)$, representing prevention of surplus food, and used as benchmark for the ideal 195 management. Scenario I (CM) represents the current management of individual French retail 196 outlets, in that only one out of 20 retailers sends a share of its surplus fruit and vegetables to 197 animal feed, while all remaining retailers send the surplus food to redistribution only. In the 198 default case we considered that no losses occurred when surplus food is redistributed, 
assuming that beneficiaries (or intermediate, e.g. charities) would waste the same amount if they would buy it or receive it from another party.

As illustrated in Figure 1, the surplus food generated is sorted on site and a share is sent to redistribution and/or animal feeding, while the rest (composed of food and packaging) to the waste management system in place, thus becoming food waste conforming to the definitions in section 2.1. According to Ministère de la Transition Écologique et Solidaire (2017a), food waste should be treated either through composting or anaerobic digestion, though the retail outlets analysed in this study send it to anaerobic digestion only. As food waste also includes packaging, pre-treatment is needed. Following the results of Bernstad et al. (2013), we assume that pre-treatment incurs $20 \%$ mass losses (i.e. all input-packaging and a share of the food) to be incinerated. The anaerobic digestion of food waste produces two outputs: biogas and digestate, with the former used to produce electricity and heat, while the latter is used as organic fertiliser. The residues are sorted out and transported to an incineration plant, according to the trends presented in the study by Ademe (2016). Thermal efficiencies (as a percentage of the incoming lower heating value of the waste, on a wet basis) at the incineration plant are $5.7 \%$ for electricity production and $41.2 \%$ for heat production, conforming with the average figures provided by a recent publication covering the entire French incineration sector (Beylot et al., 2017). Bottom ashes are assumed used for road construction, and fly ashes for backfilling of salt mines.

In Scenario II ( $A D)$, surplus food is sent to anaerobic digestion, thus becoming waste. After pre-treatment, the separated food waste is digested, while a residual waste flow composed of both packaging and food waste is incinerated. The two streams are modelled similar to Scenario I $(C M)$. Likewise, in Scenario III (I), surplus food is incinerated directly 
222 (both packaging and food products; no pre-treatment is needed). Incineration is modelled 223 similarly to the other scenarios. Scenario $I V(P)$ represents an ideal situation in which $100 \%$ 224 of the surplus food is prevented, i.e. production is avoided and no waste management is 225 required. As such, all activities occurring prior to its generation are thereby avoided. 226 Accounting for these activities is necessary only in the prevention scenario to compare 227 consistently the environmental impacts of the assessed scenarios (see also previous studies 228 on prevention, most notably, Gentil et al., 2011; Martinez-Sanchez et al., 2016). For a 229 complete description of all the processes included in the scenarios, refer to Appendix A (SI). 230 The multi-functionalities of the scenarios are handled through system expansion 231 following consequential LCA principles. This means that any co-products or services arising 232 along with the management of surplus food, i.e. the functional unit, are credited by 233 accounting for the substitution of corresponding similar market products/services (Figure 1). 234 These following consequential principles are identified in marginal products/services, i.e. 235 those likely to respond to changes in demand/supply (for details refer to e.g. Weidema, 2003; 236 Weidema et al., 2009). In our scenarios, co-products/services (Figure 1) are redistributed 237 food (to secondary selling/people/charities, etc.), fruit/vegetables reused as animal feed, 238 electricity, heat, and bottom ash used as sub-base material for road construction. With respect 239 to redistribution, a marginal food mix is defined to represent what would otherwise be 240 purchased by consumers (i.e. charities, people or third parties). It is assumed that this would 241 be composed of the cheapest food products existing on the market within the following 242 categories: Fruit and vegetables (banana (20\%), apple (20\%), potato (34\%), and carrot 243 (26\%)), Grain (pasta (63\%) and rice (37\%)), Meat (egg (65\%) and fish fingers (35\%)), and 244 Dairy (milk (75\%) and yoghurt (25\%)), which were identified based on EUROSTAT (2015). 
245 For simplicity and lack of any detailed information, each macro-category was represented by

246 two products: although consumers have multiple choices at retail outlets, forecasting changes

247 in consumption behaviours caused by redistribution and donations involve a wide range of

248 socio-economic factors (Gajjar, 2013). It is important to note that Fruit and vegetables is

249 composed of four food products, as fruits and vegetables are here aggregated into one

250 category. With respect to animal feed, marginal energy- and protein-feed are assumed to be

251 maize and soymeal, following previous studies (Tonini et al., 2018; Tonini et al., 2016). As

252 soymeal is co-produced with soy oil, the well-known soybean-loop detailed by Dalgaard et

253 al. (2008) is applied and solved. The substitution of maize and soymeal by surplus food is

254 based on relative digestible energy and protein content, following a common approach (e.g.

255 Dalgaard et al., 2008). Electricity is assumed to be produced with the French mix provided

256 in Ecoinvent v3.3 (80\% nuclear, 11\% hydro, 4\% hard coal, 3\% wind, $1 \%$ natural gas, $1 \%$

257 biogas) (Moreno Ruiz et al., 2014; IEA, 2018), while heat is assumed to be produced by 258 natural gas boilers. Natural aggregates are taken as the likely material otherwise used as sub259 base in road construction.

260

261

$* * *$ FIGURE $1 * * *$

262

$263 \quad 2.5$ Inventory data

264 2.5.1 Surplus food composition

265 The data on surplus food are based on 20 French retail outlets over a period of 13 months.

266 These data were provided by a French company that collaborates with retailers, manages the

267 bureaucratic and logistical elements of food redistribution and educates personnel working 
268 in retail outlets (Phenix, 2018). For modelling purposes, surplus food composition is 269 disaggregated into the following macro-categories according to the information provided by 270 the company: Dry sweet, Dry savoury, Frozen food, Deli meats, Fresh dairy products, Fruit 271 and vegetables, Poultry, Meat, Cheese, Gourmet, Pastry, Bakery, Fish and Liquids. The 272 primary data provided by the company were expressed as monetary values (i.e. $€$ ) and 273 represented the wholesale price, namely the price at which retailers buy the goods (FAO, 274 2018). It is assumed that the wholesale price covers both food production itself and packaging 275 production. Based on Tonini et al. (2018), the amount of packaging was calculated for each 276 food product in each of the considered macro-categories (Table B1, SI). It is important to 277 note that in the retail outlets under assessment, fruit and vegetables are sold without any 278 packaging. Therefore, their packaging was set to zero. Process inventories for performing bottom-up LCAs are typically mass-based 280 (Clavreul et al., 2014). To apply this approach, it was necessary to convert the data from 281 euros to $\mathrm{kg}$. First, wholesale prices were collected and expressed as [€ $\left.\mathrm{kg}^{-1}\right]$. Second, to have 282 a detailed classification of the surplus food in terms of food products, the food consumption 283 pattern in France was modelled (Table B2, SI). This approach is needed to model the impacts 284 of food production using a bottom-up LCA when detailed disaggregated data on the 285 individual food products composing the mix (in this case, the surplus food) are not available, 286 as explained in recent studies (see Scherhaufer et al., 2018 and Tonini et al., 2018). Finally, 287 the wholesale prices were weighted accordingly to the French consumption pattern (Table 288 B3, SI), and then the contribution of each macro-category to total surplus food, both in 289 monetary and mass terms, was calculated (Figure 2). The chemical/biochemical/physical 290 properties of the individual food products were based on Tonini et al. (2018). 
294 On average, across the 20 retail outlets, surplus food is mainly composed in monetary terms 295 by Fruit and vegetables (23\%), Deli meats (17\%), and Fresh dairy products (13\%). Mass296 wise, the highest shares are associated with Fruit and vegetables (29\%), Fresh dairy products 297 (23\%), and Bakery (19\%). When looking at surplus food in monetary terms, Deli meats 298 contributes more than Bakery due to the higher wholesale price (Table B3, SI). Overall, these 299 results are in accordance with previous studies. For example, according to Teuber \& Jensen 300 (2016), most surplus food in terms of mass is associated with bread and bakery products, and 301 fruit and vegetables. This is also supported by the study of Parfitt et al. (2010): most of 302 surplus food includes fruit and vegetables, followed by bakery, dairy, meat and fish. This 303 trend is also reflected in our results. Eventual differences in the ranking of the macro304 categories might be due to the different retail outlets analysed, to the assumed wholesale 305 prices, and to a different definition of the macro-categories (i.e. the specific food products 306 included in each one).

\subsubsection{Food production and distribution}

309 The consequential database provided by Ecoinvent v3.3 was used to model the production of 310 the food products (Wernet et al., 2016) (Table C1, SI). Their transport from the production 311 stage to the retail sector was also based on information provided by Wernet et al. (2016).

312 With respect to Fruit and vegetables, the transport inventory from Ecoinvent v3.3 already 313 accounts for the food losses (12\%) between the retail sector and the consumer (Gustavsson 
314 et al., 2011). To avoid double-counting, these losses were disregarded here. The industrial 315 processing of meat, fish, flour and bread was based on the 2-0 LCA consultants (2007) (refer 316 to Tonini et al., 2018, SI Tables S13, S14, S15). For drinks, the production process was based 317 on information provided in Doublet et al. (2013) (refer to Tonini et al., 2018, SI Table S16). 318 Cooling and storage at the retail were also based on 2-0 LCA consultants (refer to Tonini et 319 al., 2018, SI Table S17).

\subsubsection{Land-use changes}

322 Following a consequential approach, the demand for/ prevention of an additional unit of food 323 incurs a demand/prevention for land. This may be supplied by a combination of expansion 324 on virgin nature and intensification of current production (e.g. see Schmidt et al., 2013 and 325 Tonini et al., 2016) incurring (indirect) LUC effects. To include such impacts, we follow the 326 modelling approach detailed in Tonini et al. (2016) and recently applied in a study on food 327 waste management in the UK (Tonini et al., 2018). Please refer to the original publications 328 for more details. Table D1 (SI) reports the land required for each food product included in 329 the study.

\subsection{Uncertainties: scenario analyses}

332 To test the influence of choices in respect to marginal products/services (section 2.4), we 333 performed three scenario analyses consisting in: i) changing the marginal electricity mix from 334 the French mix provided in Ecoinvent v3.3 to 100\% natural gas-based electricity, ii) changing 335 the marginal food mix from the one that was detailed in section 2.4 to $100 \%$ bread and iii) 336 changing the marginal food mix from the one that was detailed in section 2.4 to assuming 
337 that this would have exactly the same composition as the surplus food coming from the retail

338 outlets (one-to-one product substitution). This equals to say that the portion of redistributed

339 food is modelled as if it was prevented. Additionally, we also performed a scenario analysis

340 on the fate of packaging, assuming $100 \%$ of food packaging is separated and recycled,

341 thereby displacing virgin paper and virgin polyethylene terephthalate, polypropylene and

342 polyethylene production. Finally, we also performed a fifth scenario analysis where we tested

343 the assumption of not having losses when surplus food is redistributed (stated in section 2.4).

344 According to Alexander \& Smaje (2008) we assumed that beneficiaries waste $32 \%$ of the

345 surplus food that they receive.

346

$347 \quad 2.7$ Cost analysis of the management of surplus food and food waste

348 A cost analysis was performed for Scenario I (CM) to illustrate economic implications for

349 French retailers after the enforcement of law no. 2016-138. Retailers benefit from a tax credit

350 of $60 \%\left(t_{c}\right.$ in Eq. 1$)$ on the monetary value of the food redistributed $(d)$. Other companies

351 typically take part in the redistribution process by handling administrative aspects and

352 logistics. This service is added to the tax credits that retailers obtain for redistributing food,

353 here assumed to correspond to about $35 \%(f)$ of the abovementioned amount. In addition, the

354 management of the (remaining) food waste is also addressed when calculating the costs

355 incurred by retailers $\left(C_{s f}\right)$. As detailed in section 2.4 , the analysed retailers send food waste

356 to anaerobic digestion only, with a gate fee assumed to be $57 € \mathrm{t}^{-1}\left(g_{f}\right)$ based on average values

357 for the EU (Hogg, 2002). Notice that, while an EU average was here chosen for simplicity

358 based on Hogg (2002), this figure nevertheless well represents fees in EU that currently span 
359 between -5 and $78 € \mathrm{t}^{-1}$ (Wrap, 2018). Thereby, the overall cost is calculated as follows, where

$360 f_{d}$ is the share of donated food and $f_{w}$ is the share of food waste in Scenario I $(C M)$ :

361

362

363

364

365

366

367

368

369

370

371

372

373

374

375

376

377

378

379

380

381

$$
C_{s f}[€]=f_{d} * d *\left(-t_{c}+t_{c} * f\right)+f_{w} * g_{f} \quad \text { Eq. } 1
$$

The economic gain generated in Scenario I (CM) was compared to the costs associated with Scenario II (AD) and Scenario III (I) (assumed at, respectively, 57 and $132 € \mathrm{t}^{-1}$ from Hogg (2002). It is important to note that Eq. 1 does not account for the costs incurred when retailers purchase food products, as these would be the same regardless of the surplus food management system implemented, i.e. the same for $C M, A D$ and $I$.

\section{Results}

The LCA results are presented in Figure 3 as characterised impacts per tonne of surplus food (including associated packaging), wet weight basis. The results obtained for Scenario I (CM) when assessing the two-different marginal food mixes (see section 2.6) are also displayed. The three remaining scenario analyses (natural gas-based electricity mix, $100 \%$ recycling of packaging, and including the losses from redistribution) are also thoroughly discussed, but, for the purpose of clarity, they are illustrated in the SI (Figures E1, E2, and E3). The complete list of the results and impact contributions may be found in Table F1 (SI).

\footnotetext{
$* * *$ FIGURE $3 * * *$
}

\subsection{LCA results: overall hierarchy and priorities for surplus food management}


382 The trend shown by the results in all ten impact categories supported a clear hierarchy: 383 surplus food prevention was, as expected, the best scenario, followed by current 384 management, which included both redistribution and use-as-feed; the waste management 385 scenarios were evidently the worst. Due to the modelling choices made in the default 386 scenario, for some of the categories, e.g. Global Warming, incineration (Scenario III (I)) 387 performed better than anaerobic digestion (Scenario II $(A D)$ ) when the marginal electricity 388 was characterised by a low-carbon mix, thereby giving a low global warming substitution 389 factor. However, when the marginal electricity was based on natural gas, Scenario II (AD) 390 performed better than Scenario III (I), as substituting electricity from natural gas induced 391 greater environmental savings, which compensated for the burden associated with processing 392 (e.g. pre-treatment, diesel, heat and electricity consumption for the operations, and fugitive $393 \mathrm{CH}_{4}$ emissions). The results illustrated that the choice of the marginal food mix had a great 394 impact on the results. When the marginal mix was composed of bread only, the savings were 395 lower than those obtained in the baseline scenario for most of the impact categories (e.g. 396 Global Warming and Fossil Resource Depletion). Conversely, when the mix was assumed to 397 have the same composition as the incoming surplus food (i.e. thus to prevent this flow fully), 398 higher savings were observed compared to the default results in most impact categories (e.g. 399 Terrestrial Acidification and Particulate Matter). This illustrates that the choice of food 400 products composing the marginal food mix is crucial with respect to the final magnitude of 401 the LCA results and that future research should improve the basis for defining this mix. In 402 respect to the scenario analysis in which packaging was fully recycled, the results did not 403 change significantly compared to the default scenario, mainly because packaging only 404 constituted $1-3 \%$ of the surplus food mix. When considering the scenario analysis where the 
405 losses incurred by beneficiaries were accounted for, the savings of Scenario I (CM)

406 decreased. However, the hierarchy of the results was not affected and the same considerations

407 can be made as for the default scenario.

408

409

3.2 Contributions to the impact

410

3.2.1 Global Warming, Fossil Resource Depletion, and Water Depletion

411

In Scenario I $(C M)$ and Scenario $I V(P)$, the main contributions to environmental benefits

412 were avoided food production, followed by the corresponding LUCs (Table F1, SI) for both

413 Global Warming and Fossil Resource Depletion. In Scenario II (AD) and Scenario III (I), the

414 main contribution to the savings was the waste management system, because of the energy

415 recovery and the substitution of alternative production sources in both of the abovementioned

416 impact categories (Table F1, SI). However, the magnitude of the benefits incurred by these

417 (-200 to $-65 \mathrm{~kg} \mathrm{CO}_{2}$-eq $\mathrm{t}^{-1}$ and -3800 to $-2000 \mathrm{MJ} \mathrm{t}^{-1}$ ) were far lower compared with those

418 obtained by prevention and redistribution pathways ( -3900 to $-400 \mathrm{~kg} \mathrm{CO}_{2}-\mathrm{eq} \mathrm{t}^{-1}$ and $-3.0 \mathrm{E}+4$

419 to $\left.-3.9 \mathrm{E}+3 \mathrm{MJ} \mathrm{t}^{-1}\right)$.

420 The impact contributions for Water Depletion for Scenario I $(C M)$ and Scenario $I V(P)$,

421 differ from those highlighted earlier in the case of Global Warming and Fossil Resource

422 Depletion. Indeed, processes fuelled by the marginal electricity (e.g. waste management,

423 refrigeration) have a great impact on this environmental category, as they are mainly

424 characterised by electricity produced from hydropower and nuclear electricity produced by a

425 pressure water reactor (Table F1, SI). When considering the default scenario assumptions,

426 the results did not follow the waste hierarchy for four out of the 20 retail outlets analysed in

427 the study. However, the waste pyramid was reflected in the results when the marginal 
428 electricity was changed to a fossil fuel-based one (i.e. natural gas), showing that the marginal

429 electricity assumed may affect the results in this category (Figure E1, SI). Furthermore, when

430 considering the default scenario assumptions results, the environmental benefits incurred by

431 Scenario II (AD) and Scenario III (I) (-2400 to $-520 \mathrm{~kg}$ water $\left.\mathrm{t}^{-1}\right)$ were lower than those

432 obtained for Scenario I (CM) and Scenario IV $(P)\left(-4100\right.$ to $-1100 \mathrm{~kg}$ water $\left.\mathrm{t}^{-1}\right)$.

434 3.2.2 Terrestrial Acidification, Photochemical Ozone Formation and Particulate Matter

435 The main contributor to savings was avoided food production, followed by the corresponding

436 LUCs for Scenario I (CM) and Scenario IV (P) (Table F1, SI). In Scenario II (AD) and

437 Scenario III (I), the main contribution to the environmental savings came from waste

438 management (Table F1, SI). Contrarily to the results for Terrestrial Acidification and

439 Particulate Matter, in the impact category Photochemical Ozone Formation Scenario III (I)

440 performed worse than Scenario II $(A D)$, due to higher emissions of $\mathrm{NO}_{\mathrm{x}}$ in the incineration 441 process.

442

443 3.2.3 Aquatic Eutrophication Nitrogen and Phosphorus

444 In Scenario I $(C M)$ and Scenario IV $(P)$, the main contributors to the environmental savings 445 were avoided food production, followed by the corresponding LUCs (Table F1, SI). With 446 respect to Scenario II (AD) and Scenario III (I), the main contribution to savings came from 447 the waste management system (Table F1, SI). The environmental benefits incurred by these

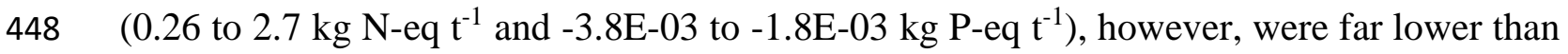
449 those obtained by the current management and the prevention scenario ( -26 to $-0.98 \mathrm{~kg}$ N-eq $450 \mathrm{t}^{-1}$ and -0.41 to $-0.049 \mathrm{~kg} \mathrm{P}$-eq $\left.\mathrm{t}^{-1}\right)$. Further, when changing the marginal food mix, a different 
451 trend was observed for the environmental category Aquatic Eutrophication Phosphorus 452 compared to, for instance, Global Warming. Indeed, compared to the baseline results, greater 453 environmental savings were obtained when changing the marginal food mix to $100 \%$ bread.

\subsubsection{Human Toxicity, cancer and Ecotoxicity}

456 The main contributors to the environmental savings in Scenario I $(C M)$ and Scenario IV $(P)$ 457 were food production followed by the corresponding LUCs (Table F1, SI). In Scenario II $458(A D)$ and Scenario III (I), the main contributor to the savings was the waste management 459 system (Table F1, SI). The savings incurred by these scenarios (-140 to $-47 \mathrm{CTU}_{\mathrm{e}} \mathrm{t}^{-1}$ and management $(C M)$ and prevention $(P)$ scenarios $\left(-3700\right.$ to $-880 \mathrm{CTU}_{\mathrm{e}} \mathrm{t}^{-1}$ and $-9.3 \mathrm{E}-05$ to -

464 these eight retail outlets, Scenario I $(C M)$ led to higher savings than Scenario $I V(P)$, due to 465 the assumption made on the marginal food mix, which was rich in grains that require an 466 extensive use of herbicides and fertilisers, highly influencing the impact on the Ecotoxicity 467 environmental category. However, the waste hierarchy, with prevention as the best scenario, 468 was reflected again in the scenario analyses results when the marginal food mix was either 469 composed of $100 \%$ bread or by a mix with the same composition as surplus food generated 470 at the retail outlet, as both include food products that have a lower impact on this category.

\section{$472 \quad 3.3$ Cost analysis}


473 When comparing the costs across Scenario I (CM), Scenario II (AD) and Scenario III (I),

474 retailers have an economic gain when handling surplus food, conforming to the current

475 management (Figure 4). However, the costs of Scenario I (CM) varied for each retailer

476 (Figure 4), not only due to exogenous factors, such as weather, but also because of local

477 management affecting the redistribution of surplus food. The costs in Scenario I (CM) ranged

478 from $-40 € \mathrm{t}^{-1}$ for retail \#13, to $-410 € \mathrm{t}^{-1}$ for retail $\# 1$ (Table G1, SI). The former represented

479 a retailer redistributing the lowest amount of surplus food containing mainly Fruit and

480 vegetables, which were amongst the cheapest food products considered. The latter

481 represented instead a retailer donating the largest amount of surplus food. This indicates that

482 donating high amounts of surplus food is certainly important to achieve a maximum of

483 monetary savings, but including expensive products (both from a monetary and resource

484 perspective), such as Meat, Fish and Deli meats, increases the benefits. This is well-

485 illustrated by retailer \#19 that, while not having the largest food redistribution in terms of

486 mass, nevertheless showed economic savings larger than other retailers, as mostly expensive

487 food products were donated.

It is important to note that, even when enforcing the current surplus food management

489 with redistribution and associated savings, retailers still suffer overall net economic burdens

490 (i.e. positive values in Figure 4) as soon as they generate surplus food. This is clearly evident

491 when the costs incurred for purchasing food products are included in the economic analysis

492 (Figure 4; see indicator "Total cost including the purchase of food"). However, the total cost

493 suffered is lower when implementing redistribution and diversion to animal feed practices

494 and minimising the amount of food waste, i.e. when implementing Scenario I (CM). 


\section{Discussion}

\subsection{Comparison of the results with previous studies}

500 Eriksson et al. (2015) performed a LCA in which the environmental benefits of redistributing

$5011 \mathrm{~kg}$ of food waste (including packaging) in the retail sector were assessed. According to the 502 study, greater environmental benefits were associated with prevention and redistribution (i.e. 503 the higher levels of the waste hierarchy) compared to composting, anaerobic digestion, use504 as-feed, incineration, and landfilling. However, the results did not show a clear trend: 505 depending on the food product characteristics, anaerobic digestion was in some cases 506 preferable to animal feed production and redistribution. Such a trend is not in accordance 507 with our results, mainly due to differences in methodological choices. Among these, the most 508 important is the inclusion of indirect LUCs in our study, which has a great impact on the 509 carbon footprint of biomasses, as illustrated in the extensive literature on biofuels/biomasses 510 (e.g. Tonini et al., 2016). As such, neglecting LUCs may result in incorrect conclusions by 511 underestimating the Global Warming impacts. The other methodological choices 512 contributing, albeit to a lesser extent, to the difference in the results of the studies are the 513 assumptions on the substituted products (animal feed, food mix, and energy mix). For 514 example, the choice of the marginal redistribution mix can highly vary the benefits obtained 515 from redistributing surplus food, and this can be seen in Eriksson et al. (2015) where a 516 substitution of $100 \%$ bread was assumed and resulted not to be highly beneficial for the

517 environment. The conclusions of Brancoli et al. (2017) are fully in agreement with those of 518 our study and support the waste hierarchy: using surplus food as animal feed instead of 
519 producing energy appeared environmentally beneficial owing to the avoided production (and

520 avoided LUCs) of conventional animal feeds. Brancoli et al. (2017) also demonstrated that

521 recycling packaging further increased the savings, albeit this is not evident from the results

522 of our study because of its low share in the mix. Eriksson \& Spångberg (2017) also assessed

523 the effect of food redistribution, though not including indirect LUCs. The results, though

524 different in magnitude because of not including LUCs, are nevertheless in agreement with

525 our study and support the waste hierarchy: donating surplus food and re-using it is

526 environmentally preferable to conversion for energy purposes. Oldfield et al. (2016)

527 evaluated the carbon footprint of different food waste management options in Ireland

528 (including all food supply chain sectors), including the retail sector. In agreement with our

529 results, food waste minimisation, i.e. prevention, was found to provide the largest savings.

530 Overall, our results, in combination with other studies in the literature, thereby question the

531 current and widely established focus of utilising surplus food for biogas production through

532 anaerobic digestion. If feasible, the food should be redistributed or utilised for animal feed,

533 thus minimising food waste flows and costs (Lebersorger \& Schneider, 2014).

534

$535 \quad 4.2$ Economic implications

536 The cost analysis on the 20 retailers varied greatly from month to month for Scenario I $(C M)$,

537 due mainly to exogenous factors, e.g. weather, tourism, seasonality, etc., as also explained

538 elsewhere (COMERSO/OID consulting/TRINOV, 2016). Considerable variations between

539 the individual retailers were also observed. This was most likely influenced by managerial

540 choices as well as by differences in local implementations of the French regulation, e.g.

541 challenges associated with establishing an action plan, and time required by personnel to 
542 familiarise and adjust to the regulation (COMERSO/OID consulting/TRINOV, 2016). As

543 expensive food products, e.g. animal-based, represented both high wholesale prices and

544 environmental impacts, maximising their redistribution should be encouraged. The cost

545 analysis fully supported the waste hierarchy: the current management involving

546 redistribution and/or animal feed offered lower costs than the traditional waste management-

547 focused scenarios involving energy production (Scenario II (AD) and Scenario III (I)).

548

$549 \quad$ 4.3 Data uncertainty and future perspectives

550 The main source of uncertainty in this study relates to the primary data provided, which are

551 expressed as monetary values (i.e. $€$ ) and need therefore to be converted into masses (i.e. $\mathrm{kg}$ )

552 to apply a bottom-up LCA approach. This conversion included several assumptions that

553 caused uncertainty in the data used in the environmental assessment. Indeed, the wholesale

554 prices used as conversion factors (expressed as $€ \mathrm{~kg}^{-1}$ ) were not all based on French statistics,

555 and they were found only for a limited number of the food products included in the macro-

556 categories. However, adding an uncertainty on the conversion factors used would only affect

557 the composition of the surplus food. We believe that including 20 different retail outlets well

558 represents the variability in the composition of surplus food. Further, the focus of the present

559 study is not on comparing the performance of the individual retail outlets, but rather to assess

560 the impact trend of different management options for surplus food. Additional uncertainties

561 are associated with the modelling of the food products composing the macro-categories. As

562 discussed in Tonini et al. (2018), the choice of the background dataset to model the food

563 production processes affects the magnitude of the results significantly. Another source of

564 uncertainty is the marginal food mix, as the results of the scenario analyses did indeed show 
565 that this affects the magnitude of the savings incurred by redistribution. Some studies (e.g.

566 Eriksson et al., 2015) even tested the assumption that the substitution effect would be null,

567 meaning that people in need (themselves or through charities/third parties) would not

568 otherwise purchase food. This assumption ultimately implies death. Another source of

569 uncertainty relates to the French food consumption pattern used to disaggregate macro-

570 categories into the individual food products composing them, as this pattern was based on

571 several studies that were performed in different years. Considering these uncertainties, the

572 numerical results of the study should be used carefully, as a different mix of food products

573 constituting the surplus food would lead to a (even substantially) different magnitude of the

574 results. However, while the magnitude of the environmental impacts may change following

575 a different assortment of food products composing the mix, the ranking of the management

576 scenarios is unlikely to be affected, as also illustrated and discussed in Tonini et al. (2018).

577 To improve the robustness of the results, we envision as necessary to: i) facilitate the

578 access to disaggregated food surplus and food waste data (i.e. breakdown of specific food

579 products, e.g. chicken, beef, cheese, etc.) both in terms of mass and price, ii)improve the

580 identification of the marginal food mix (substitution effects), and iii) elaborate up-to-date and

581 consistent (consequential and non) databases for all food products available in the market.

582

583 5. Conclusion

584 Based on a life cycle assessment of 20 French retail outlets, the results clearly indicate that 585 surplus food management in the retail sector should prioritise redistribution through 586 donations and/or conversion to animal feed over anaerobic digestion and incineration. 587 Accounting for individual food product categories in the surplus food mix, land-use changes 
588 associated with food production, and food production itself resulted in Global Warming

589 savings of -1900 to $-400 \mathrm{~kg} \mathrm{CO}_{2}-\mathrm{eq} \mathrm{t}^{-1}$ when surplus food was redistributed and diverted to

590 animal feed. The economic gains for the French retailers were in the range of -410 to $-40 € \mathrm{t}^{-}$

$591{ }^{1}$ of surplus food donated. By offering incentives, in particular through a tax credit system

592 for donating expensive food products, such as meat, the French regulation also provides

593 incentives to increase environmental savings, as relatively greater environmental impacts are

594 often associated with these food products. This suggests that the current focus in many

595 countries on directing surplus food to anaerobic digestion cannot be justified by

596 environmental arguments; rather, the focus should be directed towards promoting food

597 redistribution, e.g. by addressing liability aspects, food labelling and durability, as well as

598 economic incentives. While the results obtained herein for the French retailers are considered

599 generally applicable, the study provides a consistent basis for also evaluating similar

600 initiatives in other countries according with their waste management system and policy

601 framework.

602

603 Disclaimer

604 The views expressed in the article are the sole responsibility of the authors and in no way 605 represent the view of the European Commission and its services.

606

607 Declaration of interest:

608 None. 


\section{Acknowledgements}

610 This study was supported by "SustEnergy" (Energy Technology Development and

611 Demonstration Program, EUDP, under the Danish Energy Agency); and by the Technical

612 University of Denmark (DTU). Further, we would like to thank Susanna Andreasi Bassi and 613 Arnaud Dechesne for their comments on a draft version of the manuscript.

614 
2-0 LCA Consultants (2007). LCA Food Database. Available at http://gefionau.dk/lcafood/. 617 Accessed on June 2016.

618 Ademe (2016). Déchets - Chiffres Clés. Ademe. Available at https://www.ademe.fr/dechets-

619 chiffres-cles. Accessed on July 2018.

620 Alexander, C., \& Smaje, C. (2008). Surplus retail food redistribution: An anlysis of a third 621 sector model. Resources, Conservation and Recycling 52, pp. 1290-1298.

622 Bernstad, A., Malmquist, L., Truedsson, C, \& la Cour Jansen, J. (2013). Need for 623 Improvements in Physical Pretreatment of Source-Separated Household Food Waste. Waste 624 Management 33 (3): 746-54. https://doi.org/10.1016/j.wasman.2012.06.012

625 Beylot, A., Hochar, A., Michel, P., Descat, M., Ménard, Y., \& Villeneuve, J. (2017). 626 Municipal Solid Waste Incineration in France; An Overview of Air Pollution Control 627 Techniques, Emissions, and Energy Efficiency. Journal of Industrial Ecology 00 (0) : 1-11. 628 https://doi.org/10.1111/jiec.12701

629 Brancoli, P., Rousta, K., \& Bolton, K. (2017). Life Cycle Assessment of Supermarket Food 630 Waste. Resources, Conservation and Recycling 118. Elsevier B.V.: 39-46. 631 https://doi.org/10.1016/j.resconrec.2016.11.024

632 Buratti, C., Barbanera, M., Testarmata, \& Fantozzi, F. (2015). Life Cycle Assessment of 633 organic waste management strategies : an Italian case study. Journal of Cleaner Production 634 89, 125-136. https://doi.org/10.1016/j.jclepro.2014.11.012

635 Clavreul, J., Baumeister, H., Christensen, T. H., \& Damgaard, A. (2014). An environmental 
636 assessment system for environmental technologies. Environ. Modell. Softw. 60, 18-30.

637 https://doi.org/10.1016/j.envsoft.2014.06.007

638 COMERSO/OID company/TRINOV (2016). La distribution engagée Contre Le Gaspillage 639 Alimentaire - Synthese - 9 Pages. Available at www.ademe.fr/mediatheque\%0AToute

640 Cristóbal, J., Limleamthong, P., Manfredi, S., \& Guillén-Gosálbez, G. (2016). Methodology

641 for combined use of data envelopment analysis and life cycle assessment applied to food 642 waste management. Journal of Cleaner Production 135, 158-168. 643 https://doi.org/10.1016/j.jclepro.2016.06.085

644 Dalgaard, R., Schmidt, J., Halberg, N., Christensen, P., Thrane, M., \& Pengue, W. A. (2008).

645 LCA of Soybean Meal. International Journal of Life Cycle Assessment 13 (3) : 240-54.

646 https://doi.org/10.1065/lca2007.06.342

647 Deloitte (2014). Comparative Study on EU Member States. Legislation and Practices on 648 Food Donation. Available at https://www.eesc.europa.eu/resources/docs/executive649 summary_comparative-study-on-eu-member-states-legislation-and-practices-on-food650 donation.pdf. Accessed on 10/07/2018

651 Doublet, G., Jungblkuth, N., Stucky, M., \& Schori, S. (2013). Harmonised environmental 652 sustainability in the European food and drink products. SENSE project: ESU-services Ltd. 653 Available at http://esu-services.ch/fileadmin/download/doublet-2013-SENSE_Deliverable654 2_1-LCAorangejuice.pdf

655 Eriksson, M (2015). Supermarket Food Waste: Prevention and Management with the Focus 656 on Reduced for Reduced Carbon Footprint. 
658 Eriksson, M., \& Spångberg, J. (2017). Carbon Footprint and Energy Use of Food Waste 659 Management Options for Fresh Fruit and Vegetables from Supermarkets. Waste 660 Management 60, 786-99. https://doi.org/10.1016/j.wasman.2017.01.008

661 Eriksson, M., Strid, I., \& Hansson, P. A. (2015). Carbon Footprint of Food Waste 662 Management Options in the Waste Hierarchy - A Swedish Case Study. Journal of Cleaner 663 Production 93, 115-25. https://doi.org/10.1016/j.jclepro.2015.01.026

664 European Commission (2009). Commission Notice. Guidelines for the feed use of food no 665 longer intended for human consumption C/2018/2035. Available at https://eur666 lex.europa.eu/legal-content/EN/TXT/?uri=CELEX\%3A52018XC0416\%2801\%29

667 European Commission (2010). Guidance on the implementation of articles 11, 12, 14, 17, 66818,19 and 20 of Regulation (EC) N ${ }^{\circ}$ 178/2002 on General Food Law. Conclusions of the 669 standing committee on the food chain and animal health. Available at 670 https://ec.europa.eu/food/sites/food/files/safety/docs/gfl_req_guidance_rev_8_en.pdf

671 European Commission (2017a). Official Journal of the European Union, C361. Vol. 60. 672 Available at https://eur-lex.europa.eu/legal673 content/EN/TXT/?uri=OJ\%3AC\%3A2017\%3A361\%3AFULL. Accessed on 10/07/2018

674 European Commission (2017b). Commission Notice of 16.10.2017. EU guidelines on food 675 donation. Available at https://ec.europa.eu/food/sites/food/files/safety/docs/fw_eu676 actions_food-donation_eu-guidelines_en.pdf

677 European Federation of Food Banks, FoodDrinkEurope, \& EuroCommerce (2016). Every 
678 Meal Matter - $\quad$ Food Donation Guidelines. Available at

679 http://www.fooddrinkeurope.eu/publication/every-meal-matters-food-donation-guidelines/.

680 European Parliament and Council (2008). Directive 2008/98/EC of the European Parliament

681 and of the Council of 19 November 2008 on Waste and Repealing Certain Directives. Official

682 Journal of the European Union, 3-30. https://doi.org/2008/98/EC.; 32008L0098

683 European Union (2017). Distribution of Foodstuff Surpluses to Most Deprived Persons and 684 Limitation of Food Waste: Information from the Italian Delegation. 685 http://data.consilium.europa.eu/doc/document/ST-6008-2017-INIT/en/pdf

686 EUROSTAT (2015). Database. Detailed average prices. 687 http://ec.europa.eu/eurostat/web/hicp/data/database (accessed on 20/03/2018)

688 FAO (2018). 4. Concepts on price data. Available at http://www.fao.org/economic/the689 statistics-division-ess/methodology/methodology-systems/price-statistics-and-index690 numbers-of-agricultural-production-and-prices/4-concepts-on-price-data/en/

691 Forster, P., Ramaswamy, V., Artaxo, P., Berntsen, T., Betts, R., Fahey, D. W., Haywood, J., 692 Lean, J., Lowe, D. C., Myhre, G., Nganga, J., Prinn, R., Raga, G., Schulz, M., \& van Dorland, 693 R. (2007). Changes in atmospheric constituents and in radiative forcing. In: Solomon, S., 694 Qin, D., Manning, M., Chen, Z., Marquis, M., Averyt, K. B., Tignor, M., \& Miller, H. L. 695 (Eds), Climate change 2007: The Physical Science Basis. Contribution of Working Group I 696 to the Fourth Assessment Report of the Intergovernmental Panel on Climate Change. 697 Cambridge University Press, Cambridge, United Kingdom and New York, NY, USA, pp. $698 \quad 130-234$. 
699 Gajjar, N. B. (2013). Factors Affecting Consumer Behavior. Raijmr Com 1 (2) : 10-15.

700 https://raijmronlineresearch.files.wordpress.com/2017/08/2_10-15-dr-nilesh-b-gajjar.pdf

701 Garot, G. (2015). Lutte contre le gaspillage alimentaire: propositions pour une politique 702 publique. Ministère de l'agriculture, de l'agroalimentaire et de la forêt. Available at 703 https://www.ladocumentationfrancaise.fr/rapports-publics/154000257/index.shtml

704 Gentil, E. C., Gallo, D., \& Christensen, T. H. (2011). "Environmental Evaluation of 705 Municipal Waste Prevention.” Waste Management $31 \quad$ (12), 2371-79. 706 https://doi.org/10.1016/j.wasman.2011.07.030

707 Goedkoop, M., Heijungs, R., Huijbregts, M., De Schryver, A., Struijs, J., \& van Zelm, R. 708 (2009). $\quad$ ReCiPe $2008 . \quad$ Potentials, 44. 709 https://www.leidenuniv.nl/cml/ssp/publications/recipe_characterisation_addenum.pdf

710 Gustavsson, J., Cederberg, C., Sonesson, U., van Otterdijk, R., \& Meybeck, A. (2011). 711 Global Food Losses and Food Waste - Extent, Causes and Prevention. 712 http://www.fao.org/docrep/014/mb060e/mb060e00.pdf

713 Hanssen, O. J., Ekegren, P., Gram-Hanssen, I., Korpela, P., Langevad-Clifforth, N., Skov714 Olsen, K., \& Svanes, R. (2014). Food Redistribution in the Nordic Region. Experiences and 715 Results from a Pilot Study. https://doi.org/10.6027/TN2014-562

716 Hogg, D. (2002). Costs for Municipal Waste Management in the EU. Final Report to 717 Directorate General Environment. European Commission. Eunomia Research \& Consulting. 718 http://ec.europa.eu/environment/waste/studies/pdf/eucostwaste.pdf

719 IEA (2018). France: Electricity and Heat for 2015. 
$720 \mathrm{https}: / /$ www.iea.org/statistics/statisticssearch/report/?country=FRANCE=\&product=electric

721 ityandheat (accessed 20/03/2018)

722 ISO (2006a). Environmental Management - Life Cycle Assessment - Requirements and

723 Guidelines, first ed., ISO; Geneva, Switzerland.

724 ISO (2006b). ISO 14040: Environmental Management - Life Cycle Assessment - Principles

725 and Framework, second ed. ISO, Geneva, Switzerland.

726 Lebersorger, S., \& Schneider, F. (2014). Food loss rates at the food retail, influencing factors

727 and reasons as a basis for waste prevention measures. Waste Management 34, pp. 1911-1919.

728 Legifrance (2016). LOI n. 2016-138 du 11 Février 2016 relative à la lutte contre le gaspillage

729 alimentaire. Available at

730 https://www.legifrance.gouv.fr/affichTexte.do?cidTexte=JORFTEXT000032036289\&date

731 Texte=\&categorieLien $=\mathrm{id}$

732 Martinez-Sanchez, V., Tonini, D., Møller, F., \& Astrup, T. F. (2016). Life-Cycle Costing of 733 Food Waste Management in Denmark: Importance of Indirect Effects. Environmental 734 Science and Technology 50 (8): 4513-23. https://doi.org/10.1021/acs.est.5b03536

735 Ministère de la Transition Écologique et Solidaire (2017a). Biodèchets. 736 https://www.ecologique-solidaire.gouv.fr/biodechets\#e2 (accessed 19/03/2018)

737 Ministère de la Transition Écologique et Solidaire (2017b). Gaspillage alimentaire. 738 https://www.ecologique-solidaire.gouv.fr/gaspillage-alimentaire-0 (accessed 07/03/2018)

739 Mirosa, M., Mainvil, L., Horne, H., \& Mangan-Walker, E. (2016). The social value of 740 rescuing food, nourishing communities. British Food Journal, vol. 118 (12), pp. 3044- 
742 Moreno Ruiz, E., Lévová, T., Bourgault, G., \& Wernet, G. (2014). Documentation of 743 Changes Implemented in Ecoinvent Data 3.1. Ecoinvent 0 (5) : 70

744 Mourad, M. (2015). France Moves toward a National Policy against Food Waste. Nrdc, no. 745 September: 1-12. https://www.nrdc.org/sites/default/files/france-food-waste-policy746 report.pdf

747 Oldfield, T. L., White, E., \& Holden, N. M. (2016). An Environmental Analysis of Options 748 for Utilising Wasted Food and Food Residue. Journal of Environmental Management 183: 749 826-35. https://doi.org/10.1016/j.jenvman.2016.09.035

750 P. Forster, V. Ramaswamy, P. Artaxo, T. Berntsen, R. Betts, D.W. Fahey, J. Haywood, J. 751 Lean, D.C. Lowe, G. Myhre, J. Nganga, R. Prinn, G. Raga, M. Schulz, R. Van 752 Dorland (2007). Changes in atmospheric constituents and in radiative forcing. Contribution 753 of Working Group I to the Fourth Assessment Report of the Intergovernmental Panel on 754 Climate Change. In: Solomon S., D. Qin, M. R. Manning, Z. Chen, M. Marquis, K.B. 755 Averyt, M. Tignor, H.L. Miller (eds.), Climate Change 2007: The Physical Science 756 Basis.. Cambridge University Press, Cambridge, United Kingdom / New York, NY, 757 USA., pp.130-234.

758 Parfitt, J., Barthel, M., \& Macnaughton, S. (2010). Food Waste within Food Supply Chains: 759 Quantification and Potential for Change to 2050. Philosophical Transactions of the Royal 760 Society B : Biological Sciences 365 (1554) :3065-81. https://doi.org/10.1098/rstb.2010.0126

761 Phenix (2018). About us. http://danmark.wearephenix.com/en/about-phenix/ (accessed 
763 Rosenbaum, R. K., Huijbregts, M. A. J., Henderson, A. D., Margni, M., McKone, T. E., Van

764 De Meent, D., Hauschild, M. Z. et al. (2011). USEtox Human Exposure and Toxicity Factors

765 for Comparative Assessment of Toxic Emissions in Life Cycle Analysis: Sensitivity to Key

766 Chemical Properties. International Journal of Life Cycle Assessment 16 (8): 710-27.

767 https://doi.org/10.1007/s11367-011-0316-4

768 Scherhaufer, S., Lebersorger, S., Pertl, A., Obersteiner, G., Schneider, F., Falasconi, L., De

769 Menna, F., Vittuari, M., Hartikainen, H., Katajajuuri, J. M., Joensuu, K., Timonen, K., van 770 der Sluis, A., Bos-Brouwers, B., Moates, G., Waldron, K., Mhlanga, N., Bucatariu, C. A., 771 Lee, W. T. K., James, K., \& Easteal, S. (2015). Criteria for and baseline assessment of 772 environmental and socio-economic impacts of food waste. Available at https://www.eu773 fusions.org/index.php

774 Scherhaufer, S., Moates, G., Hartikainen, H., Waldron, K., \& Obersteiner, G. (2018). 775 Environmental impacts of food waste in Europe. Waste Management 77, 98-113

776 Schmidt, J., Weidema, B. P., \& Brandão, M. (2013). LCA Screening of Biofuels - ILUC, 777 Biomass Manipulation and Soil Carbon. Concito - Danmarks Grønne Tænketank, 1-102. 778 Available at https://lca-net.com/publications/show/lca-screening-biofuels-iluc-biomass779 manipulation-soil-carbon/. Accessed on 10/07/2018

780 Scholz, K., Eriksson, M., \& Strid, I. (2015). Carbon Footprint of Supermarket Food Waste. 781 Resources, Conservation and $\quad 94$ : $\quad$ 56-65. 782 https://doi.org/10.1016/j.resconrec.2014.11.016 
783 Schönberger, H., Galvez Martos, J. L., \& Styles, D. (2013). Best Environmental Management

784 Practice in the Retail Trade Sector. https://doi.org/10.2791/1775

785 Seppälä, J., Posch, M., Johansson, M., \& Hettelingh, J. P. (2006). Country-dependent 786 characterisation factors for acidification and terrestrial eutrophication based on accumulated 787 exceedance as an impact category indicator (14 pp). The International Journal of Life Cycle 788 Assessment, 11(6), 403-416.

789 Stenmark, Å. Jensen, C., Quested, T., \& Moates, G. (2016). Estimates of European Food 790 Waste Levels. https://doi.org/10.13140/RG.2.1.4658.4721

791 Struijs, J., Beusen, A., van Jaarsveld, H., Huijbregts, M. A. J. (2009). Aquatic eutrophication. 792 In: Goedkoop M., Heijungs R., Huijbregts M. A. J., De Schryver A., Struijs J., Van Zelm R. 793 (Eds), ReCiPe 2008. Chapter 6: A Life Cycle Impact Assessment Method Which Comprises 794 Harmonised Category Indicators at the Midpoint and the Endpoint Level. Report I: 795 Characterisation, first ed. 6 January 2009. Available at <http://www.lcia-recipe.net>.

796 Sud Ouest (2017). Gaspillage alimentaire: un an après la loi, le boom des solutions. 797 http://www.sudouest.fr/2017/02/22/gaspillage-alimentaire-un-an-apres-la-loi-le-boom-des798 solutions-anti-gaspi-3209648-6150.php (accessed 22/03/2018)

799 Teuber, R., \& Jensen, J. D. (2016). Food Losses and Food Waste: Extent, Underlying 800 Dreivers and Impact Assessment of Prevention Approaches. Department of Food and 801 Resource Economics, University of Copenhagen. IFRO Report, No. 254. 802 https://curis.ku.dk/ws/files/169753425/IFRO_Report_254.pdf 
803 Tonini, D., Albizzati, P. F., \& Astrup, T. F. (2018). Environmental Impacts of Food Waste:

804 Learnings and Challenges from a Case Study on UK. Waste Management 76: 744-66.

805 https://doi.org/10.1016/j.wasman.2018.03.032

806 Tonini, D., Hamelin, L., \& Astrup, T. F. (2016). Environmental Implications of the Use of 807 Agro-Industrial Residues for Biorefineries: Application of a Deterministic Model for Indirect 808 Land-Use Changes. GCB Bioenergy 8 (4):690-706. https://doi.org/10.1111/gcbb.12290

809 Tonini, D., Martinez-Sanchez, V., \& Astrup, T.F. (2013). Material Resources, Energy, and 810 Nutrient Recovery from Waste: Are Waste Refineries the Solution for the Future?. 811 Environmental Science and Technology 47 (15), pp. 8962-8969. DOI: 10.1021/es400998y

812 United Nations (2015). Transforming our world: The 2030 agenda for sustainable 813 development. Resolution adopted by the General Assembly. Available at 814 https://sustainabledevelopment.un.org/content/documents/21252030\%20Agenda\%20for\%2 815 0Sustainable\%20Development\%20web.pdf

816 van Zelm, R., Huijbregts, M. A. J., den Hollander, H. A., van Jaarsveld, H. A., Sauter, F. J., 817 Struijs, J., van Wijnen, H. J., \& van de Meent, D. (2008). European characterization factors 818 for human health damage of PM10 and ozone in life cycle impact assessment. Atmospheric 819 Environment, 42(3), 441-453.

820 Vandermeersch, T., Alvarenga, A. F., Ragaert, P., \& Dewulf, J. (2014). Environmental 821 Sustainability Assessment of Food Waste Valorization Options. Resources, Conservation 822 and Recycling 87 : 57-64. https://doi.org/10.1016/j.resconrec.2014.03.008 
823 Vittuari, M., De Menna, F., Gaiani, S., Falasconi, L., Politano, A., Dietershagen, J., \& Segré, 824 A. (2017). The Second Life of Food: An Assessment of the Social Impact of Food 825 Redistribution Activities in Emilia Romagna, Italy. Sustainability, 9 (10), 1817.

826 van Oers, L., De Koning, A., Guinée, J. B., \& Huppes, G. (2002). Abiotic ressource Depletion 827 in LCA. Public Works and Water Management, no. June: 1-75.

828 Weidema, B. P. (2003). Market Information in Life Cycle Assessment. Danish Ministry of 829 the Environment. Environemtnal Project no. 863. https://lca830 net.com/publications/show/market-information-life-cycle-assessment/

831 Weidema, B. P., Ekvall, T., \& Heijungs, R. (2009). Guidelines for Application of Deepened 832 and Broadened LCA. 833 https://pdfs.semanticscholar.org/8be5/9252f6790328a6360d506df522de78bbce4c.pdf

834 Wernet, G., Bauer, C., Steubing, B., Reinhard, J., Moreno-Ruiz, E., \& Weidema, B. (2016). 835 The ecoinvent database version 3 (part I): overview and methodology. The International 836 Journal of Life Cycle Assessment, [online] 21(9), pp.1218-1230. Available at: 837 http://link.springer.com/10.1007/s11367-016-1087-8 [Accessed 09/03/2018]

838 Wrap (2018). Comparing the costs of alternative waste treatment options. Anthesis.

839 Available at

840 http://www.wrap.org.uk/sites/files/wrap/WRAP\%20Gate\%20Fees\%202018_exec+extende 841 d\%20summary\%20report_FINAL.pdf 


\section{Highlights:}

Environmental impacts of surplus food management scenarios assessed for 20 retailers; Anaerobic digestion and incineration outcompeted by redistribution and use-as-feed;

Environmental and economic assessment results support the waste hierarchy priorities;

Practices favouring redistribution and use-as-feed should be encouraged;

Further research needed for identification of displaced/substituted food products. 


\section{1}

2 Figure 1: The system boundaries (black, dashed line) are displayed for the four scenarios

\section{Figure Captions} considered. The black lines in 1a, 1b, and 1c indicate the processes prior to the generation of surplus food, which are not considered in Scenario I (CM), Scenario II (AD), and Scenario III (I) due to system equivalence. The grey, dashed boxes and lines represent displacement of market processes/technologies. Note that LUC (land-use-changes; here as avoided effect) accounts both for expansion and intensification. "C":collection; “T”:transport; "Figure 1a”:Scenario I (CM); “Figure 1b”:Scenario II (AD); “Figure 1c”Scenario III (I); “Figure 1d”:Scenario IV $(P)$.

10

Figure 2: Contribution of each macro-category to the total surplus food, for each retail outlet considered in the study. The graph on the left expresses the surplus food as monetary values, whereas the one on the right as mass values. Note that retailers 1 to 19 redistribute the surplus food, whilst retail \#20 both redistributes and sends it for use as animal feed.

Figure 3: Characterized results for the ten environmental impact categories, expressed per tonne of surplus food, wet weight basis. The baseline results are illustrated together with those of the scenario analyses where we change the marginal redistribution mix (see section 2.6). Values above the zero-line are burdens, whilst below are savings to the environment. “GW”: Global Warming; “TA”: Terrestrial Acidification; "POF”: Photochemical Ozone Formation; “PM”: Particulate Matter; “AE, N”: Aquatic Eutrophication, Nitrogen; “AE, P”: Aquatic Eutrophication, Phosphorus; “ET”: Ecotoxicity; “HT, cancer”: Human Toxicity, cancer; “FRD”: Fossil Resource Depletion; “WD”: Water Depletion. 
25 Figure 4: Costs [ $\left.€ \mathrm{t}^{-1}\right]$ for the management of one tonne of surplus food at each individual 26 retail outlet. For comparison, the cost for the current management (involving redistribution 27 and diversion to animal feed) is compared to a situation where $100 \%$ of the surplus food is 28 sent to either anaerobic digestion (AD; $\left.57 € \mathrm{t}^{-1}\right)$ or incineration $\left(\mathrm{I} ; 132 € \mathrm{t}^{-1}\right)$. Costs are shown 29 with and without including the upstream cost incurred by the retailers for purchasing the 30 food. Note that negative costs are savings, and positive costs are expenses. 


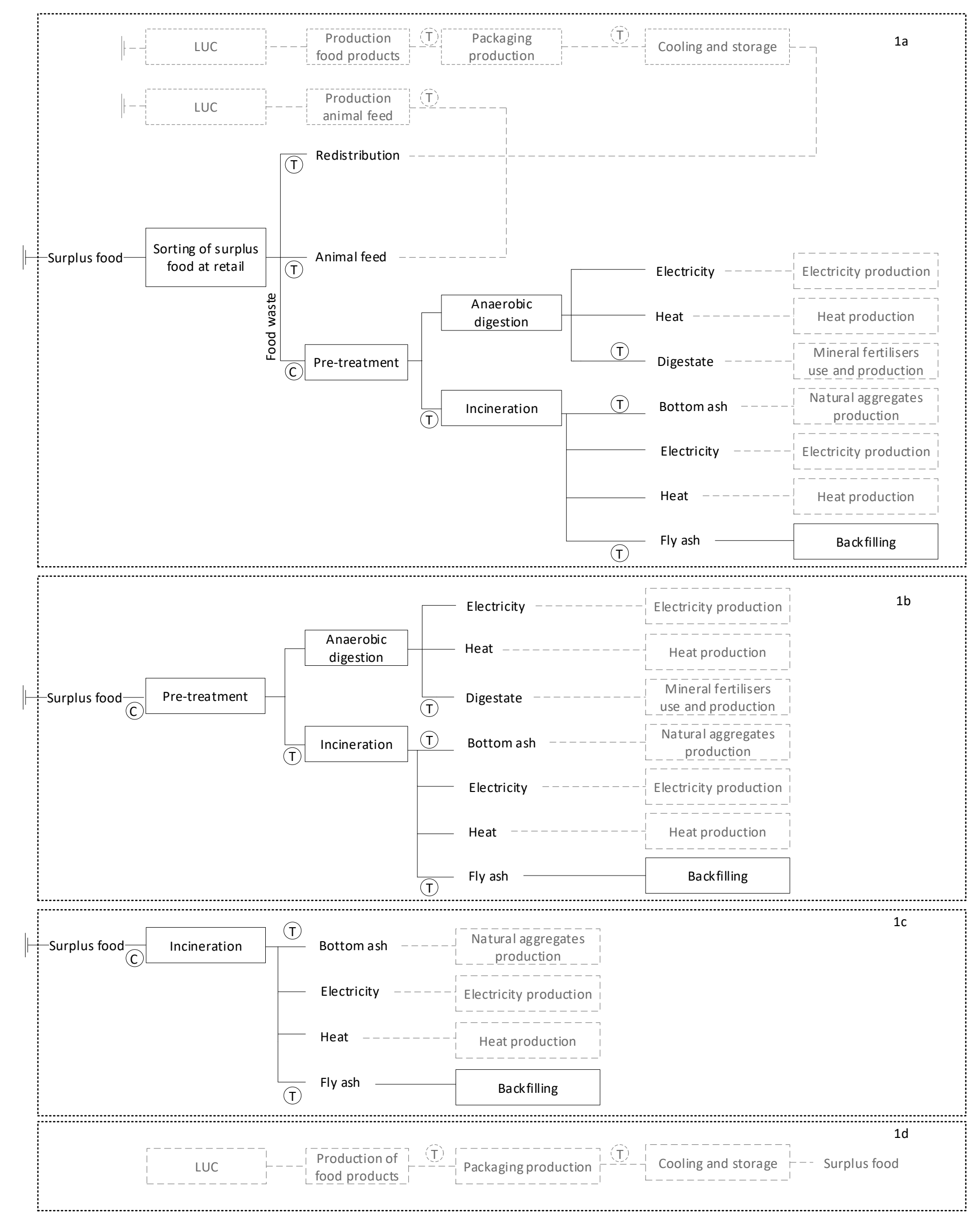


Surplus food $[€]$

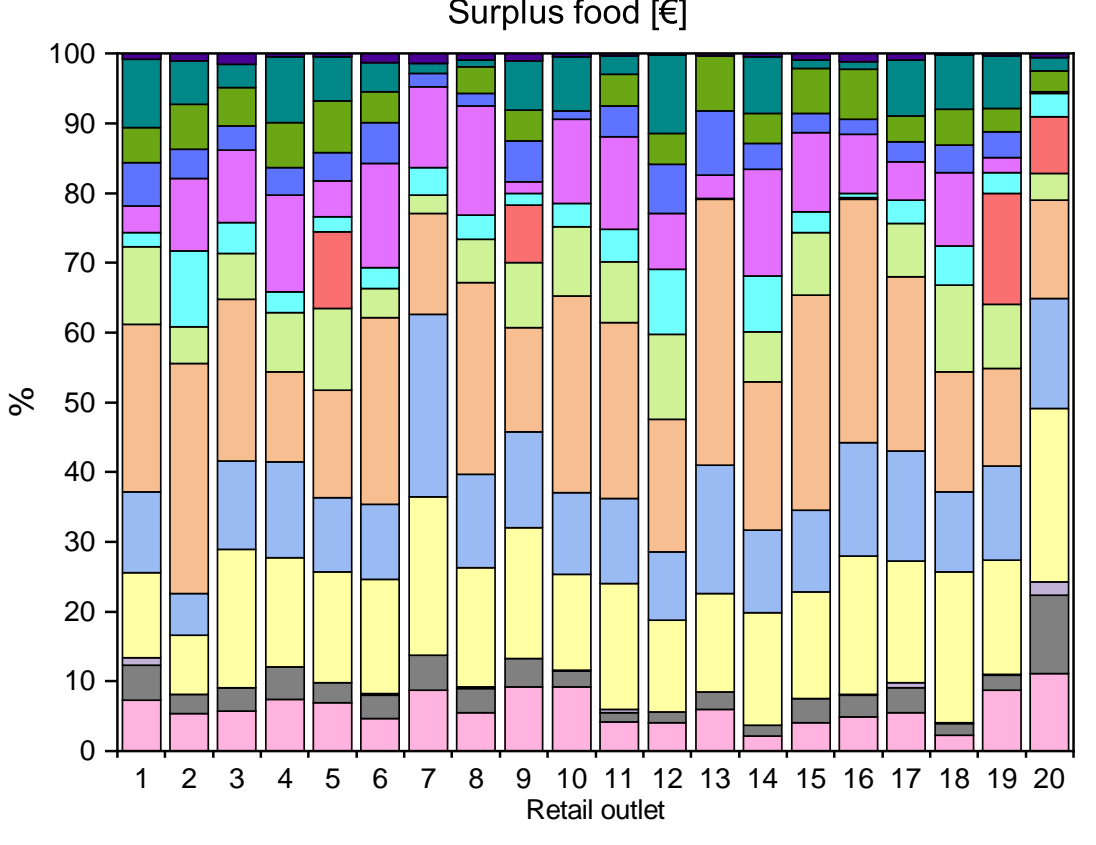

Surplus food [kg]

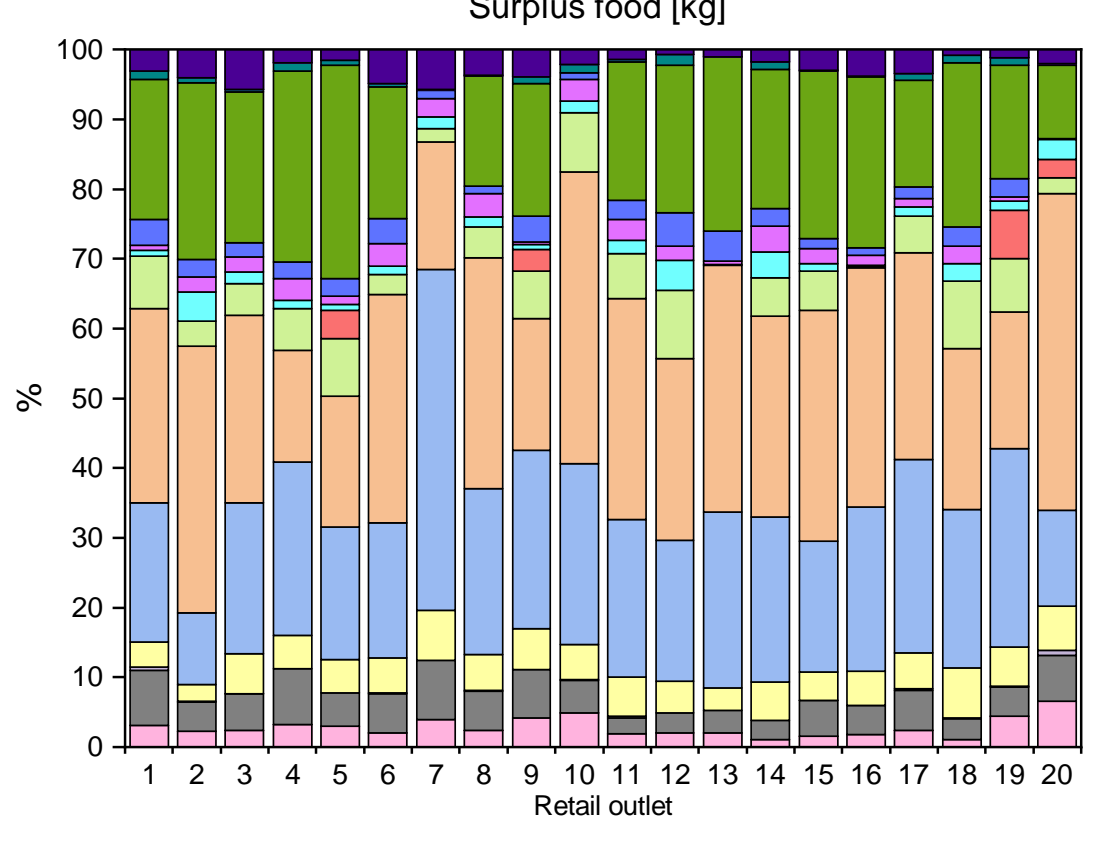

$\square$ Liquids $\square$ Fish $\square$ Bakery $\square$ Pastry $\square$ Gourmet $\square$ Cheese $\square$ Meat $\square$ Poultry $\square$ Fruits and vegetables $\square$ Fresh dairy products $\square$ Deli meats $\square$ Frozen food $\square$ Dry savory $\square$ Dry sweet 



- Scenario I (CM) - default - Scenario II (AD) $\quad \nabla \quad$ Scenario III (I) $\quad$ Scenario IV (P)

\& Scenario I (CM) - mix 


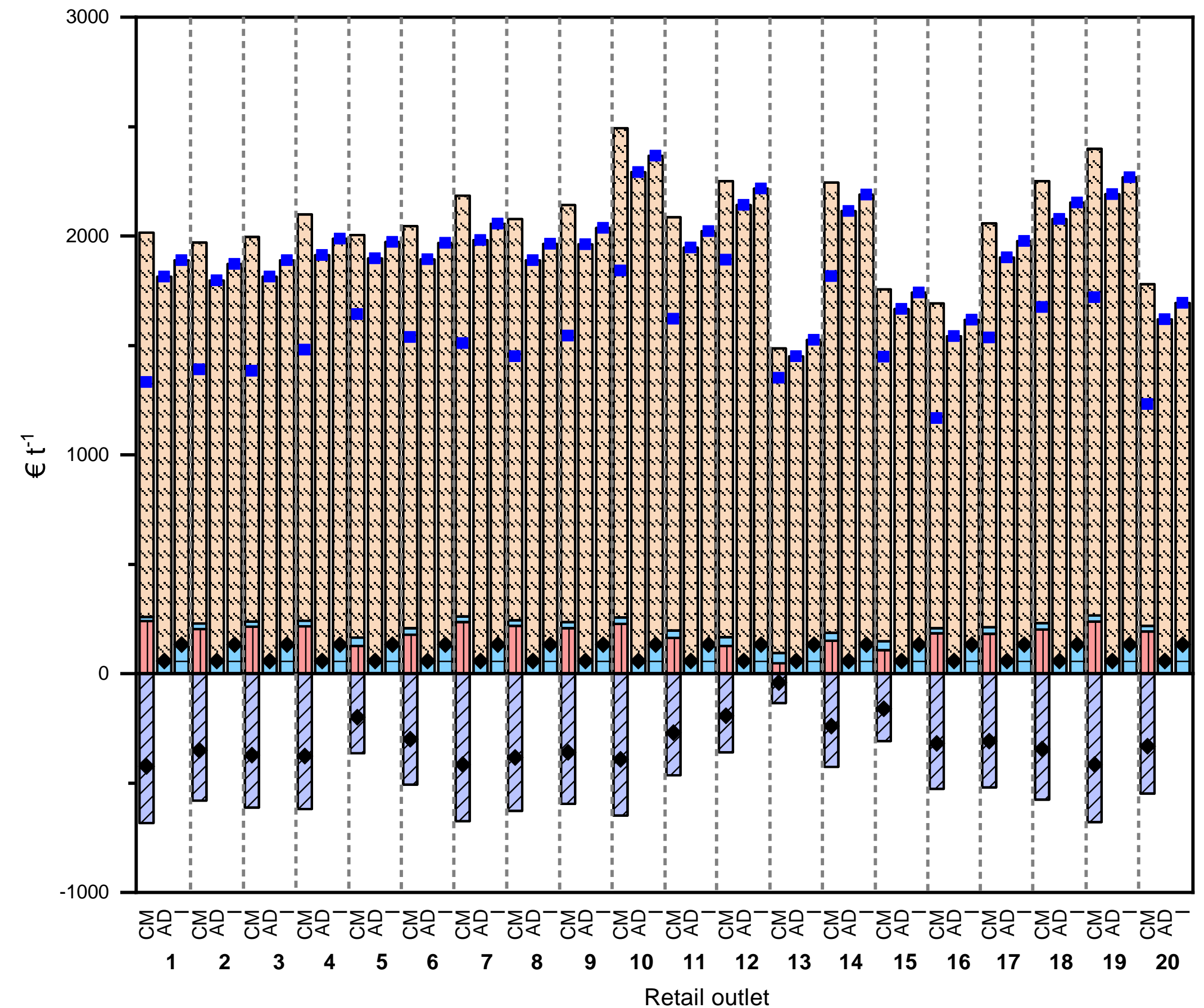




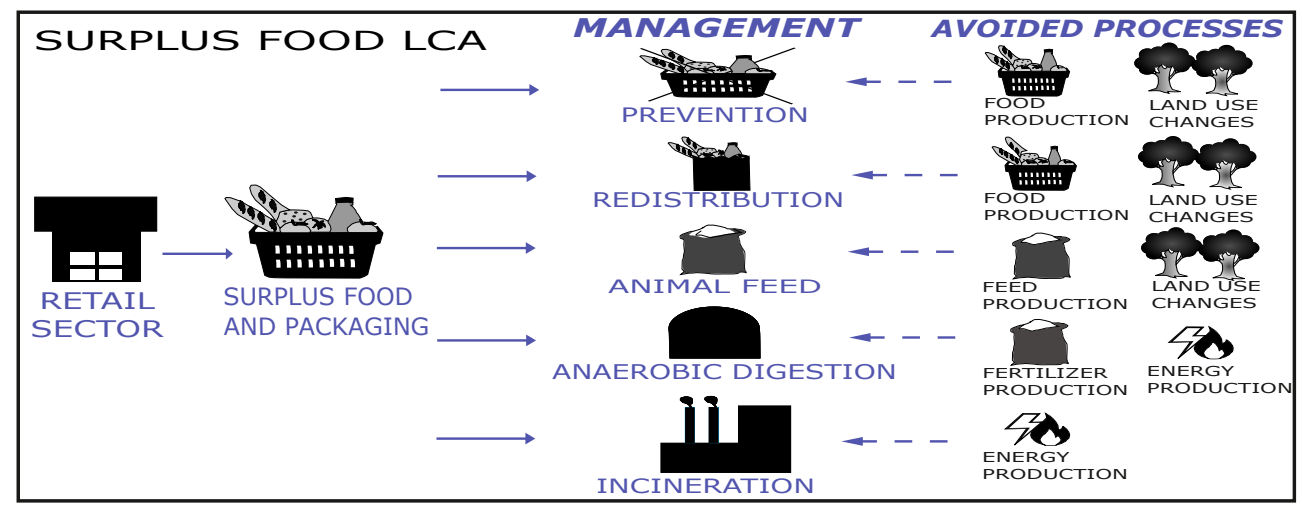


For the article: sector: Environmental and economic impacts

8 Paola Federica Albizzati ${ }^{1}$, Davide Tonini ${ }^{2}$, Charlotte Boyer Chammard ${ }^{3}$, Thomas Fruergaard

${ }^{1}$ Technical University of Denmark, Department of Environmental Engineering, Bygninstorvet 113, 2800 Lyngby, Denmark

12 Joint Research Centre of the European Commission, Edificio Expo, Inca Garcilaso 3, 41092 


\section{Table of Contents}

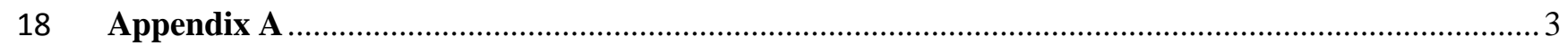

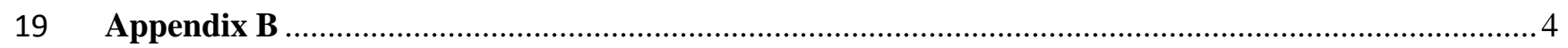

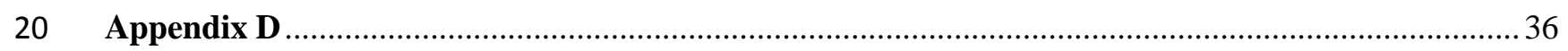

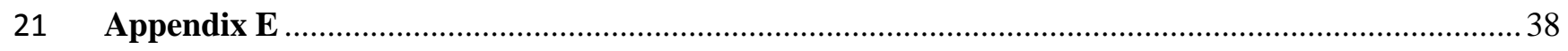

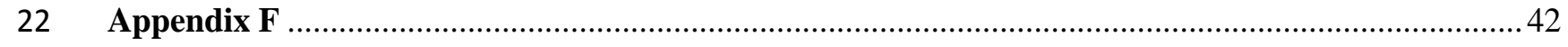

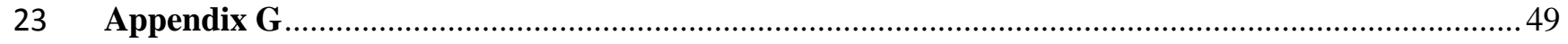

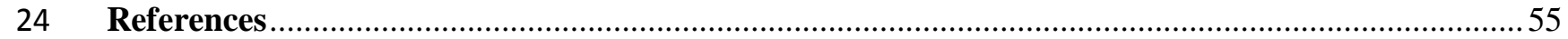

25

26 


\section{Appendix A}

28 Herein a detailed list of all the processes included in the system boundaries of each scenario is presented. In Scenario $29 I(C M)$, Scenario II (AD), Scenario III (I) (Figure 1a, 1b, 1c, respectively in the main report), the system boundaries 30 account for: the collection of the surplus food, the redistribution process, the use of the surplus food as animal feed,

31 transport, the digestion of the food waste, and the incineration of the residual waste flows (i.e. from pre-treatment,

32 both food and packaging). The boundaries are further expanded to account for, when applicable: the avoided indirect

33 land use changes (both intensification and expansion) due to food production, the avoided production of food products

34 and the corresponding packaging, the avoided transport of the food products and the corresponding packaging, the

35 avoided cooling and storage of the food products at retails, the avoided production of the conventional animal feed 36 and its transport, the avoided indirect land use changes (both intensification and expansion) due to animal feed

37 production, the avoided production of marginal heat, electricity, mineral fertilizers, gravel and natural aggregates. In

38 Scenario IV $(P)$ (Figure 1d in the main report), the system boundaries include: the indirect land use changes due to the 39 production of the food products (both intensification and expansion), the production of food products, the transport 40 and refrigeration of the food products, the packaging production, the transport of the packaging, and the cooling and 41 storage at retails. 


\section{Appendix B}

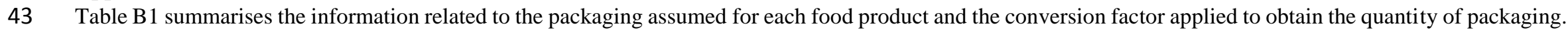

44 Notice that in the retails considered in the study, Fruit and vegetables are sold without packaging. Hence, their packaging was set to 0.

Table B2 provides the information regarding the assumed French consumption pattern together with the food products included and their share in each macro-category. The French consumption pattern was characterized based on Agence française de sécurité sanitarie des aliments (2007), Interfel (2018), Maison

47 du Lait (2018), Les fabricants de Biscuits \& Gâteaux de France (2016), and France AgriMer (2014).

Table B3 presents the conversion factors of the wholesale prices expressed as $\left[€ \mathrm{~kg}^{-1}\right]$. Note that the wholesale prices were based on Ministère de

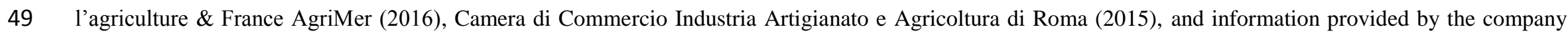

50 Phenix. The conversion factors reported in Table B3 where obtained by weighting the wholesale prices accordingly to the French consumption pattern.

51 Table B1: Information regarding the type of packaging assumed for all the food products included in the mix. The conversion factor expressed as [ $\mathrm{kg}_{\text {packaging }} \mathrm{kg}_{\text {food product }}{ }^{-1}$ ] is also 52 reported.

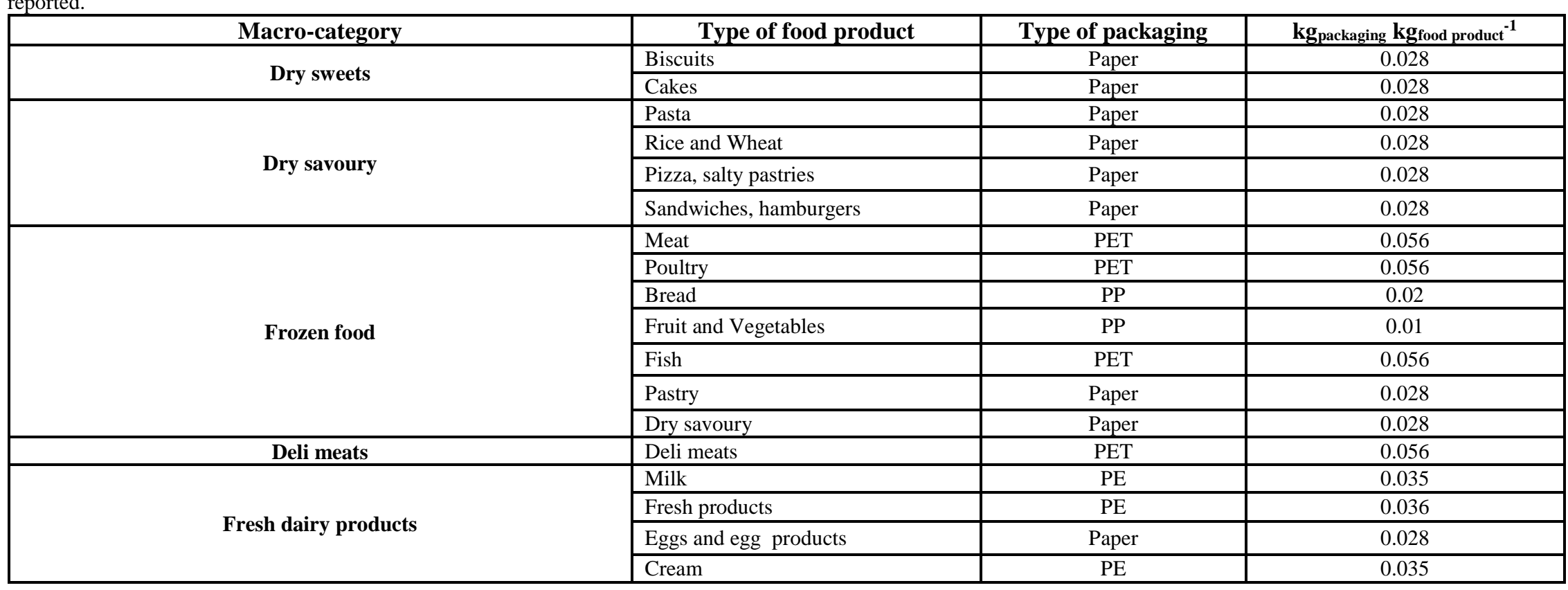




\begin{tabular}{|c|c|c|c|}
\hline & Butter & PP & 0.02 \\
\hline \multirow{37}{*}{ Fruit and Vegetables } & Potato & - & 0 \\
\hline & Apple & - & 0 \\
\hline & Tomato & - & 0 \\
\hline & Banana & - & 0 \\
\hline & Orange & - & 0 \\
\hline & Lettuce & - & 0 \\
\hline & Carrot & - & 0 \\
\hline & Clementine & - & 0 \\
\hline & Peach & - & 0 \\
\hline & Melon & - & 0 \\
\hline & Pear & - & 0 \\
\hline & Endive & - & 0 \\
\hline & Chicory & - & 0 \\
\hline & Zucchini & - & 0 \\
\hline & Onion & - & 0 \\
\hline & Pepper & - & 0 \\
\hline & Grape & - & 0 \\
\hline & Cucumber & - & 0 \\
\hline & Lemon & - & 0 \\
\hline & Watermelon & - & 0 \\
\hline & Pomelo & - & 0 \\
\hline & Kiwi & - & 0 \\
\hline & Strawberry & - & 0 \\
\hline & Leek & - & 0 \\
\hline & Avocado & - & 0 \\
\hline & Apricot & - & 0 \\
\hline & Plum & - & 0 \\
\hline & Beetroot & - & 0 \\
\hline & Champignon & - & 0 \\
\hline & Pineapple & - & 0 \\
\hline & Cauliflower & - & 0 \\
\hline & Artichoke & - & 0 \\
\hline & Celeriac & - & 0 \\
\hline & Savoy cabbage & - & 0 \\
\hline & Radish & - & 0 \\
\hline & Walnut & - & 0 \\
\hline & Broccoli & - & 0 \\
\hline
\end{tabular}




\begin{tabular}{|c|c|c|c|}
\hline & Pumpkin & - & 0 \\
\hline & \begin{tabular}{|l|} 
Shallot \\
\end{tabular} & - & 0 \\
\hline & Celery & - & 0 \\
\hline & Aubergine & - & 0 \\
\hline & Valerian & - & 0 \\
\hline & Asparagus & - & 0 \\
\hline & Chestnuts & - & 0 \\
\hline & Spinach & - & 0 \\
\hline & Cherry & - & 0 \\
\hline & Green beans & - & 0 \\
\hline & Fennel & - & 0 \\
\hline & Turnip & - & 0 \\
\hline & Brussels sprouts & - & 0 \\
\hline & Peas & - & 0 \\
\hline \multirow{6}{*}{ Poultry } & Chicken & PET & 0.056 \\
\hline & Elaborated poultry & PET & 0.056 \\
\hline & Turkey & PET & 0.056 \\
\hline & Other poultry & PET & 0.056 \\
\hline & Duck & PET & 0.056 \\
\hline & Fresh rabbit & PET & 0.056 \\
\hline \multirow{8}{*}{ Meat } & Fresh pork & PET & 0.056 \\
\hline & Beef & PET & 0.056 \\
\hline & Other elaborated & PET & 0.056 \\
\hline & Fresh minced meat & PET & 0.056 \\
\hline & Veal & PET & 0.056 \\
\hline & Ovine & PET & 0.056 \\
\hline & Offal of meat & PET & 0.056 \\
\hline & Horse & PET & 0.056 \\
\hline $\begin{array}{l}\text { Cheese } \\
\end{array}$ & Cheese & $\mathrm{PP}$ & 0.02 \\
\hline Gourmet & Gourmet & Paper & 0.028 \\
\hline \multirow{2}{*}{ Pastry } & Pastries and cakes & Paper & 0.028 \\
\hline & Croissants & Paper & 0.028 \\
\hline Bakery & Bread & PP & 0.02 \\
\hline \multirow{2}{*}{ Fish } & Fish & PET & 0.056 \\
\hline & Shellfish and molluscs & PET & 0.056 \\
\hline \multirow{2}{*}{ Liquids } & Water & $\mathrm{PE}$ & 0.035 \\
\hline & Non-alcoholic beverages & $\mathrm{PE}$ & 0.035 \\
\hline
\end{tabular}


54 Table B2: The assumed French consumption pattern is presented together with the food products included in each macro-category and their contribution to it

\begin{tabular}{|c|c|c|}
\hline Macro-category & Food products & Share [\%] \\
\hline \multirow{2}{*}{ Dry sweet } & Biscuits & 85 \\
\hline & Cakes & 15 \\
\hline \multirow{4}{*}{ Dry savoury } & Pasta & 38.1 \\
\hline & Rice and Wheat & 24 \\
\hline & Pizza, salty pastries & 22.2 \\
\hline & Sandwiches, hamburgers & 15.7 \\
\hline \multirow{7}{*}{ Frozen food } & Meat & 14.3 \\
\hline & Poultry & 14.3 \\
\hline & Bread & 14.3 \\
\hline & Fruit and vegetables & 14.3 \\
\hline & Fish & 14.3 \\
\hline & Pastry & 14.3 \\
\hline & Dry savoury & 14.3 \\
\hline Deli meats & Deli meats & 100 \\
\hline \multirow{5}{*}{ Fresh dairy products } & Milk & 48.7 \\
\hline & Yogurt & 35.9 \\
\hline & Eggs and egg products & 6.7 \\
\hline & Cream & 4.7 \\
\hline & Butter & 4 \\
\hline \multirow{19}{*}{ Fruit and Vegetables } & Potato & 26.7 \\
\hline & Apple & 6.5 \\
\hline & Tomato & 5.7 \\
\hline & Banana & 4.9 \\
\hline & Orange & 4.5 \\
\hline & Lettuce & 4.1 \\
\hline & Carrot & 3.6 \\
\hline & Clementine & 3.2 \\
\hline & Peach, melon & 2.4 \\
\hline & Pear, endive, chicory, zucchini, onion & 2 \\
\hline & Pepper, grape, cucumber & 1.6 \\
\hline & Lemon & 1.5 \\
\hline & Watermelon & 1.3 \\
\hline & Pomelo, kiwi, strawberry, leek & 1.2 \\
\hline & Avocado & 1 \\
\hline & Apricot & 0.9 \\
\hline & Plum, beetroot, champignon, pineapple, cauliflower & 0.8 \\
\hline & Artichoke & 0.7 \\
\hline & Celeriac, savoy cabbage, radish & 0.6 \\
\hline
\end{tabular}




\begin{tabular}{|c|c|c|}
\hline & Walnut, broccoli & 0.5 \\
\hline & Pumpkin, shallot, celery, aubergine & 0.4 \\
\hline & Valerian, asparagus, chestnut, spinach, cherry, green beans, fennel, turnip & 0.3 \\
\hline & Brussels sprouts, peas & 0.1 \\
\hline \multirow{6}{*}{ Poultry } & Chicken & 44 \\
\hline & Elaborated poultry & 24.4 \\
\hline & Turkey & 12.7 \\
\hline & Other poultry & 7.7 \\
\hline & Duck & 5.8 \\
\hline & Fresh rabbit & 5.5 \\
\hline \multirow{8}{*}{ Meat } & Fresh pork & 25.1 \\
\hline & Beef & 22.7 \\
\hline & Other elaborated & 21.5 \\
\hline & Fresh minced meat & 12.2 \\
\hline & Veal & 7.4 \\
\hline & Ovine & 6 \\
\hline & Offal of meat & 4.3 \\
\hline & Horse & 0.8 \\
\hline Cheese & Cheese & 100 \\
\hline Gourmet & Gourmet & 100 \\
\hline \multirow{2}{*}{ Pastry } & Pastries and cakes & 74.1 \\
\hline & Croissants & 25.9 \\
\hline Bakery & Bread & 100 \\
\hline \multirow{2}{*}{ Fish } & Fish & 86.7 \\
\hline & Shellfish and molluscs & 13.3 \\
\hline \multirow{2}{*}{ Liquids } & Water & 82.8 \\
\hline & Non-alcoholic beverages & 17.2 \\
\hline
\end{tabular}


Table B3: Conversion factors of the wholesale prices of the macro-categories considered in the study.

\begin{tabular}{|l|c|}
\hline \multicolumn{1}{|c|}{ Macro-category } & Conversion factor $\left[\mathbf{\epsilon} \mathbf{~ k g}^{-1}\right]$ \\
\hline Dry sweet & 4.17 \\
\hline Dry savoury & 1.105 \\
\hline Frozen food & 4.06 \\
\hline Deli meats & 6.06 \\
\hline $\begin{array}{l}\text { Fresh dairy } \\
\text { products }\end{array}$ & 1.019 \\
\hline $\begin{array}{l}\text { Fruit and } \\
\text { Vegetables }\end{array}$ & 1.508 \\
\hline Poultry & 2.6 \\
\hline Meat & 4.891 \\
\hline Cheese & 4.49 \\
\hline Gourmet & 8.45 \\
\hline Pastry & 3.01 \\
\hline Bakery & 0.44 \\
\hline Fish & 14.85 \\
\hline Liquids & 0.47 \\
\hline
\end{tabular}


59 Table $\mathrm{C} 1$ provides the processes used for the modelling of the food products considered in the study. Both the assumptions made, the processes used to model the

60 production and transport of the food products are listed. All the processes are based on Ecoinvent v3.3 Consequential (Wernet et al., 2016).

61 Table C1: List of processes based on Ecoinvent v3.3 Consequential (Wernet et al., 2016) for the modelling of the food products considered in the study.

\begin{tabular}{|c|c|c|c|c|}
\hline Macro-categories & $\begin{array}{c}\text { Food } \\
\text { products }\end{array}$ & $\begin{array}{c}\text { Assumptions for } \\
\text { LCA modelling } \\
\end{array}$ & $\begin{array}{c}\text { Process(es) in Ecoinvent for the } \\
\text { production }\end{array}$ & Process(es) in Ecoinvent for the transport \\
\hline \multirow[b]{2}{*}{ Dry sweet } & Biscuits & $\begin{array}{l}\text { Estimated on a mix of } \\
\text { ingredients based on } \\
\text { Halaal Recipes (2017). } \\
\text { The energy consumption } \\
\text { is based on Masanet et al. } \\
\text { (2012). }\end{array}$ & $\begin{array}{l}\text { - } \quad \text { Butter production, from cow milk; GLO } \\
\text { - } \quad \text { Beet sugar production; } \text { RoW } \\
\quad \text { GLO } \\
\text { - Electricity production, natural gas, } \\
\quad \text { conventional power plant; } \text { RoW } \\
\text { - Wheat flour; GLO }\end{array}$ & $\begin{array}{l}\text { - } \quad \text { Transport, freight train; } F R \\
\text { - } \\
\text { Transport freight inland waterways, barge; } \\
\text { - } \quad \text { Transport, freight, lorry, all sizes, EURO4 to } \\
\text { generic market for transport, freight, lorry, } \\
\quad \text { unspecified; RoW } \\
\text { - } \\
\text { Transport, freight, sea, transoceanic ship; GLO }\end{array}$ \\
\hline & Cakes & $\begin{array}{l}\text { Estimated on a mix of } \\
\text { ingredients based on Paul } \\
\text { Holliwood (2017). The } \\
\text { energy consumption is } \\
\text { based on Masanet et al. } \\
\text { (2012). }\end{array}$ & 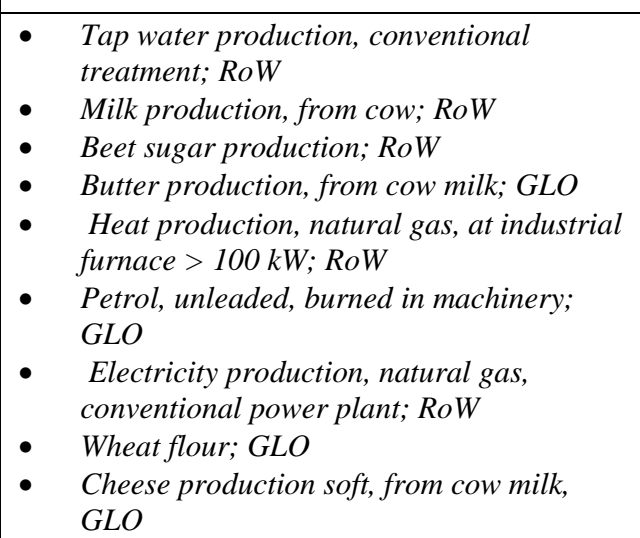 & $\begin{array}{ll}- & \text { Transport, freight train; } F R \\
\text { - } & \text { Transport freight inland waterways, barge; } \\
& \text { RoW } \\
\text { - } & \text { Transport, freight, lorry, all sizes, EURO4 to } \\
& \text { generic market for transport, freight, lorry, } \\
& \text { unspecified; RoW } \\
\text { - } & \text { Transport, freight, sea, transoceanic ship; GLO }\end{array}$ \\
\hline
\end{tabular}




\begin{tabular}{|c|c|c|c|c|}
\hline \multirow{4}{*}{ Dry savoury } & Pasta & $\begin{array}{l}\text { Based on the LCI } \\
\text { reported in the study by } \\
\text { Lo Giudice \& Clasadonte } \\
\text { (2014) }\end{array}$ & $\begin{array}{l}\text { For the semolina production: } \\
\text { - } \quad \text { Electricity production, natural gas, } \\
\text { conventional power plant; RoW } \\
\text { - } \quad \text { Tap water production, conventional } \\
\text { treatment; RoW } \\
\text { - } \quad \text { Natural gas, burned in gas motor, for } \\
\text { storage; RoW } \\
\text { - } \quad \text { Wheat production; } \text { GLO } \\
\text { For the pasta production: } \\
\text { - } \quad \text { Semolina production } \\
\text { - } \quad \text { Electricity production, natural gas, } \\
\text { - } \quad \text { Tanventional power plant, RoW } \\
\quad \text { treatment; } \text { RoW } \\
\text { - Petrol, unleaded, burned in machinery; } \\
\quad \text { GLO }\end{array}$ & $\begin{array}{ll}\text { - } & \text { Transport, freight train; FR } \\
\text { - } & \text { Transport freight inland waterways, barge; } \\
\text { RoW } \\
\text { - } \\
\text { Transport, freight, lorry, all sizes, EURO4 to } \\
\text { generic market for transport, freight, lorry, } \\
\text { unspecified; RoW } \\
\text { - Transport, freight, sea, transoceanic ship; GLO }\end{array}$ \\
\hline & Rice & & - $\quad$ Rice production; $G L O$ & $\begin{array}{l}\text { - } \quad \text { Transport, freight train; FR } \\
\text { - } \quad \text { Transport freight inland waterways, barge; } \\
\text { RoW } \\
\text { - } \\
\text { Transport, freight, lorry, all sizes, EURO4 to } \\
\text { generic market for transport, freight, lorry, } \\
\text { unspecified; RoW } \\
\text { - Transport, freight, sea, transoceanic ship; GLO }\end{array}$ \\
\hline & Wheat & & - Wheat production; $G L O$ & $\begin{array}{ll}\text { - } & \text { Transport, freight train; FR } \\
\text { - } & \text { Transport freight inland waterways, barge; } \\
& \text { RoW } \\
\text { - } & \text { Transport, freight, lorry, all sizes, EURO4 to } \\
\text { generic market for transport, freight, lorry, } \\
\text { unspecified; RoW } \\
\text { - Transport, freight, sea, transoceanic ship; GLO }\end{array}$ \\
\hline & $\begin{array}{l}\text { Pizza, salty } \\
\text { pastries }\end{array}$ & $\begin{array}{l}\text { Estimated on a mix of } \\
\text { ingredients based on } \\
\text { Lillywhite et al. (2013). }\end{array}$ & $\begin{array}{l}\text { - } \quad \text { Tomato production, fresh grade, open field; } \\
\text { RoW } \\
\text { - } \quad \text { Cheese production, soft, from cow milk; } \\
\text { GLO } \\
\text { - } \quad \text { Cattle } \\
\text { - } \quad \text { Natural gas, burned in gas motor, for } \\
\text { - } \quad \text { torage; } \text { RoW } \\
\quad \text { Wheat flour; GLO }\end{array}$ & $\begin{array}{l}\text { - } \quad \text { Transport, freight train; FR } \\
\text { Transport freight inland waterways, barge; } \\
\text { RoW } \\
\text { - Transport, freight, lorry, all sizes, EURO4 to } \\
\text { generic market for transport, freight, lorry, } \\
\text { unspecified; RoW } \\
\text { Transport, freight, sea, transoceanic ship; GLO }\end{array}$ \\
\hline
\end{tabular}




\begin{tabular}{|c|c|c|c|c|}
\hline & $\begin{array}{l}\text { Sandwiches,h } \\
\text { amburgers }\end{array}$ & $\begin{array}{l}\text { Assumed as Pizza, salty } \\
\text { pastries }\end{array}$ & $\begin{array}{l}\text { - } \quad \text { Tomato production, fresh grade, open field; } \\
\text { RoW } \\
\text { - Cheese production, soft, from cow milk; } \\
\text { GLO Cattle for slaughtering, live weight to } \\
\text { generic market for red meat, live weight; } \\
\text { GLO } \\
\text { - Natural gas, burned in gas motor, for } \\
\text { storage; RoW } \\
\text { - Wheat flour; GLO } \\
\text { - Cattle }\end{array}$ & $\begin{array}{ll}- & \text { Transport, freight train; FR } \\
\text { - } & \text { Transport freight inland waterways, barge; } \\
& \text { RoW } \\
\text { - } & \text { Transport, freight, lorry, all sizes, EURO4 to } \\
\text { generic market for transport, freight, lorry, } \\
\text { unspecified; RoW } \\
\text { - Transport, freight, sea, transoceanic ship; GLO }\end{array}$ \\
\hline \multirow{6}{*}{ Frozen food } & Meat & $\begin{array}{l}\text { Calculated as the average } \\
\text { of all the Meat items }\end{array}$ & $\begin{array}{lr}\text { Average of: } \\
\text { - } \quad \text { Swine } e^{2} \\
\text { - } \quad \text { Cattle }^{l} \\
\text { - } \quad \text { Sheep }^{3}\end{array}$ & $\begin{array}{l}\text { Average of: } \\
-\quad \text { Transport of swine } \\
\text { - } \quad \text { Transport of cattle } \\
\text { - } \quad \text { Transport of sheep }\end{array}$ \\
\hline & Poultry & $\begin{array}{l}\text { Calculated as the average } \\
\text { of all the Poultry items }\end{array}$ & - $\quad$ Chicken $^{4}$ & $\begin{array}{l}\text { - Transport, freight, lorry, all sizes, EURO } 4 \text { to } \\
\text { generic market for transport, freight, lorry, } \\
\text { unspecified; RoW }\end{array}$ \\
\hline & Bread & $\begin{array}{l}\text { Based on LCA food DK } \\
\text { "Bread, wheat, } \\
\text { conventional fresh" (2-0 } \\
\text { LCA Consultants, 2007). }\end{array}$ & $\begin{array}{l}\text { - } \quad \text { Drinking water from groundwater, RER, } \\
\text { ELCD 2005-corrected } \\
\text { - } \quad \text { Wheat flour: GLO } \\
\text { - } \quad \text { Market for electricity, low voltage; GB } \\
\text { - Marginal heat; } U K\end{array}$ & $\begin{array}{l}\text { - } \quad \text { Transport, freight train; FR } \\
\text { Transport freight inland waterways, barge; } \\
\text { RoW } \\
\text { Transport, freight, lorry, all sizes, EURO4 to } \\
\text { generic market for transport, freight, lorry, } \\
\text { unspecified; RoW } \\
\text { - Transport, freight, sea, transoceanic ship; GLO }\end{array}$ \\
\hline & $\begin{array}{l}\text { Fruits and } \\
\text { Vegetables }\end{array}$ & $\begin{array}{l}\text { Assumed as the average } \\
\text { of all the Fruit and } \\
\text { Vegetables items }\end{array}$ & All the fruit and vegetables items (see list below) & $\begin{array}{c}\text { Calculated as the average of the transport of the } \\
\text { Fruit and Vegetables }\end{array}$ \\
\hline & Fish & & - $\quad$ Fish $^{5}$ & $\begin{array}{l}\text { - Transport, freight, lorry, all sizes, EURO } 4 \text { to } \\
\text { generic market for transport, freight, lorry, } \\
\text { unspecified; RoW }\end{array}$ \\
\hline & Pastry & $\begin{array}{l}\text { Assumed as the average } \\
\text { of all the Dry sweet items }\end{array}$ & $\begin{array}{l}\text { The LCI is based on: } \\
\text { - } \quad \text { Production of croissants } \\
\text { - } \quad \text { Production of pastry }\end{array}$ & $\begin{array}{l}\text { Average of: } \\
\text { - } \quad \text { Transport of croissants } \\
\text { - } \quad \text { Transport of pastry }\end{array}$ \\
\hline
\end{tabular}




\begin{tabular}{|c|c|c|c|c|}
\hline & Dry savoury & $\begin{array}{l}\text { Assumed as the average } \\
\text { of all the Dry savoury } \\
\text { items }\end{array}$ & $\begin{array}{l}\text { The LCI is based on: } \\
\text { - } \quad \text { Production of pasta } \\
\text { - } \quad \text { Production of rice } \\
\text { - } \quad \text { Production of wheat } \\
\text { - } \quad \text { Production of pizza, salty pastries } \\
\text { of sandwiches, hamburgers }\end{array}$ & $\begin{array}{l}\text { Average of: } \\
-\quad \text { Transport of pasta } \\
\text { - } \quad \text { Transport of rice } \\
\text { - } \quad \text { Transport of wheat } \\
\text { - Transport of sand, salty pastries } \\
\quad \text { sames, hamburgers }\end{array}$ \\
\hline Deli meats & Deli meats & & - $\quad$ Swine $^{2}$ & $\begin{array}{l}\text { - Transport, freight, lorry, all sizes, EURO } 4 \text { to } \\
\text { generic market for transport, freight, lorry, } \\
\text { unspecified; RoW }\end{array}$ \\
\hline \multirow{5}{*}{ Fresh dairy products } & Milk & & - $\quad$ Milk productin, from cow, RoW & $\begin{array}{ll}- & \text { Transport, freight train; FR } \\
\text { - } & \text { Transport, freight, light commercial vehicle; } \\
& \text { RoW } \\
\text { - } & \text { Transport, freight, lorry, all sizes, EURO4 to } \\
\text { generic market for transport, freight, lorry, } \\
\text { unspecified; RoW } \\
\text { - Transport, freight, sea, transoceanic ship, GLO }\end{array}$ \\
\hline & $\begin{array}{c}\text { Fresh } \\
\text { products }\end{array}$ & & - Yogurt production, from cow milk, RoW & $\begin{array}{l}\text { - } \quad \text { Transport, freight train; FR } \\
\text { - Transport, freight, light commercial vehicle; } \\
\quad \text { RoW } \\
\text { - Transport, freight, lorry, all sizes, EURO4 to } \\
\text { generic market for transport, freight, lorry, } \\
\quad \text { unspecified; } \text { Row } \\
\text { - } \\
\text { Transport, freight, sea, transoceanic ship, GLO }\end{array}$ \\
\hline & $\begin{array}{l}\text { Eggs and egg } \\
\text { products }\end{array}$ & & $\begin{array}{l}\text { - Cheese production soft, from cow milk, } \\
\text { GLO }\end{array}$ & $\begin{array}{l}\text { Transport, freight, lorry, all sizes, EURO } 4 \text { to } \\
\text { generic market for transport, freight, lorry, } \\
\text { unspecified; } \text { RoW }\end{array}$ \\
\hline & Cream & & $\begin{array}{l}\text { - Butter proudction, from cream, from cow } \\
\text { milk; GLO }\end{array}$ & $\begin{array}{l}\text { - } \\
\text { - } \\
\quad \text { Transport, freight train; } F R \\
\text { RoW } \\
\text { - Transport, freight, light commercial vehicle; } \\
\text { generic market for transport, freight, lorry, } \\
\quad \text { unspecified; } \text { RoW } \\
\text { - Transport, freight, sea, transoceanic ship, GLO }\end{array}$ \\
\hline & Butter & & - $\quad$ Butter production, from cow milk, GLO & - $\quad$ Transport, freight train; $F R$ \\
\hline
\end{tabular}




\begin{tabular}{|c|c|c|c|}
\hline & & & $\begin{array}{ll}\text { - } & \text { Transport, freight, light commercial vehicle; } \\
& \text { RoW } \\
\text { - Transport, freight, lorry, all sizes, EURO4 to } \\
\text { generic market for transport, freight, lorry, } \\
\text { unspecified; RoW } \\
\text { - Transport, freight, sea, transoceanic ship, GLO }\end{array}$ \\
\hline \multirow{3}{*}{ Fruit and vegetables } & Potato & - $\quad$ Potato production; $G L O$ & $\begin{array}{l}\text { - Operation, reefer, cooling, 40-foot, high-cube, } \\
\text { R134a as refrigerant; GLO } \\
\text { Transport, freight, inland, waterways, barge } \\
\text { with reefer, cooling; GLO } \\
\text { Transport, freight, lorry with reefer, cooling; } \\
\text { GLO } \\
\quad \text { Transport, freight, small lorry with } \\
\text { refrigeration machine, EURO4, RI34a } \\
\text { refrigerant, cooling to generic market; GLO } \\
\text { Transport, freight, sea, transoceanic ship with } \\
\text { reefer, cooling; GLO Transport, freight, train } \\
\text { with reefer, cooling; GLO }\end{array}$ \\
\hline & Apple & - Apple production; $G L O$ & $\begin{array}{l}\text { - Operation, reefer, cooling, } 40-\text {-foot, high-cube, } \\
\text { R134a as refrigerant; GLO } \\
\text { - } \quad \text { Transport, freight, inland, waterways, barge } \\
\text { with reefer, cooling; GLO } \\
\text { - } \\
\quad \text { Gransport, freight, lorry with reefer, cooling; } \\
\text { - } \quad \text { Transport, freight, small lorry with } \\
\text { refrigeration machine, EURO4, RI34a } \\
\quad \text { refrigerant, cooling to generic market; GLO } \\
\text { - Transport, freight, sea, transoceanic ship with } \\
\quad \text { reefer, cooling; GLO } \\
\text { - Transport, freight, train with reefer, cooling; } \\
\quad \text { GLO }\end{array}$ \\
\hline & Tomato & - Tomato production; $G L O$ & $\begin{array}{l}\text { - Operation, reefer, cooling, 40-foot, high-cube, } \\
\text { Rl34a as refrigerant; GLO } \\
\text { - Transport, freight, inland, waterways, barge } \\
\text { with reefer, cooling; GLO } \\
\text { - Transport, freight, lorry with reefer, cooling; } \\
\text { GLO } \\
\text { - Transport, freight, small lorry with } \\
\text { refrigeration machine, EURO4, R134a } \\
\text { refrigerant, cooling to generic market; GLO } \\
\text { Transport, freight, sea, transoceanic ship with } \\
\text { reefer, cooling; GLO }\end{array}$ \\
\hline
\end{tabular}




\begin{tabular}{|c|c|c|}
\hline & & $\begin{array}{l}\text { - Transport, freight, train with reefer, cooling; } \\
\text { GLO }\end{array}$ \\
\hline Banana & - Banana production; $G L O$ & $\begin{array}{l}\text { Operation, reefer, cooling, } 40-\text {-foot, high-cube, } \\
\text { R134a as refrigerant; GLO } \\
\text { Transport, freight, inland, waterways, barge } \\
\text { with reefer, cooling; GLO } \\
\text { - } \text { Transport, freight, lorry with reefer, cooling; } \\
\text { GLO } \\
\text { Transport, freight, small lorry with } \\
\text { refrigeration machine, EURO4, R134a } \\
\text { refrigerant, cooling to generic market; GLO } \\
\text { Transport, freight, sea, transoceanic ship with } \\
\text { reefer, cooling; GLO } \\
\text { - Transport, freight, train with reefer, cooling; } \\
\text { GLO }\end{array}$ \\
\hline Orange & - Orange production; $G L O$ & 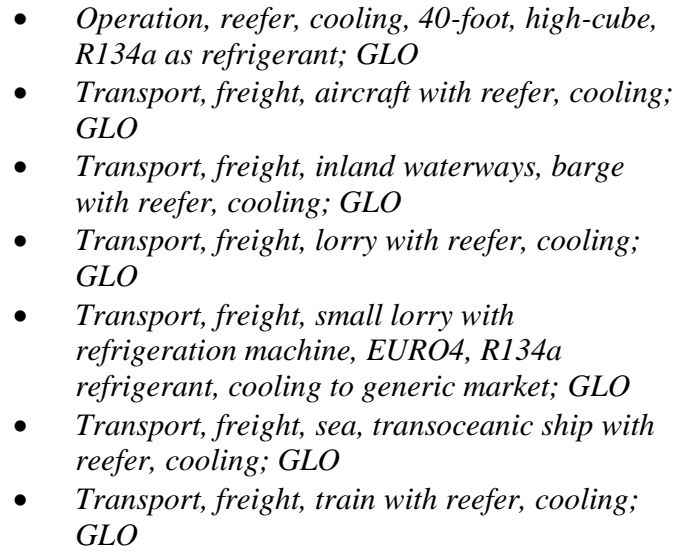 \\
\hline
\end{tabular}




\begin{tabular}{|c|c|c|}
\hline Lettuce & - Lettuce production; GLO & 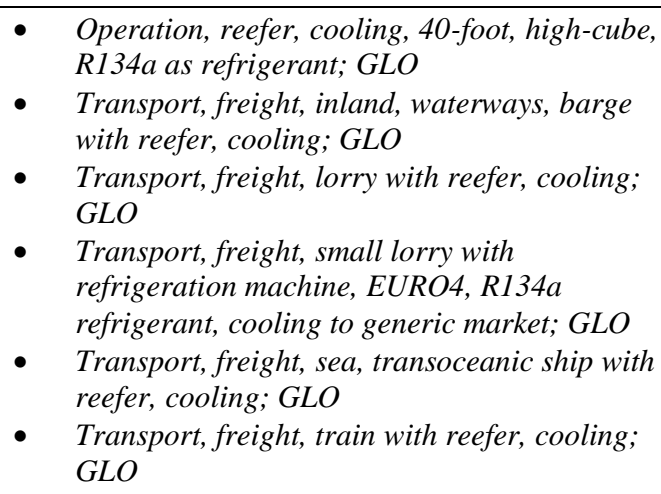 \\
\hline Carrot & - $\quad$ Carrot production; $G L O$ & $\begin{array}{ll}\text { - Operation, reefer, cooling, } 40-f o o t, \text { high-cube, } \\
\text { RI34a as refrigerant; } G L O \\
\text { - Transport, freight, inland, waterways, barge } \\
\text { with reefer, cooling; GLO } \\
\text { - Transport, freight, lorry with reefer, cooling; } \\
\quad \text { GLO } \\
\quad \text { Transport, freight, small lorry with } \\
\text { refrigeration machine, EURO4, RI34a } \\
\text { refrigerant, cooling to generic market; GLO } \\
\text { - Transport, freight, sea, transoceanic ship with } \\
\text { reefer, cooling; GLO } \\
\quad \text { Transport, freight, train with reefer, cooling, } \\
\text { GLO }\end{array}$ \\
\hline Clementine & - Mandarin production; $R o W$ & $\begin{array}{l}\text { - Operation, reefer, cooling, } 40 \text {-foot, high-cube, } \\
\text { Rl34a as refrigerant; GLO } \\
\text { - Transport, freight, inland, waterways, barge } \\
\text { with reefer, cooling; GLO } \\
\text { - Transport, freight, lorry with reefer, cooling; } \\
\text { GLO } \\
\text { - Transport, freight, small lorry with } \\
\text { refrigeration machine, EURO4, RI34a } \\
\text { refrigerant, cooling to generic market; GLO } \\
\text { - Transport, freight, sea, transoceanic ship with } \\
\text { reefer, cooling; GLO } \\
\text { - Transport, freight, train with reefer, cooling; } \\
\text { GLO }\end{array}$ \\
\hline
\end{tabular}




\begin{tabular}{|c|c|c|}
\hline Peach & - $\quad$ Peach production; $R$ RoW & $\begin{array}{l}\text { - Operation, reefer, cooling, 40-foot, high-cube, } \\
\text { Rl34a as refrigerant; GLO Transport, freight, } \\
\text { aircraft with reefer, cooling; GLO } \\
\text { - Transport, freight, inland waterways, barge } \\
\text { with reefer, cooling; GLO } \\
\text { - } \quad \text { Transport, freight, lorry with reefer, cooling; } \\
\text { GLO } \\
\text { - Transport, freight, small lorry with } \\
\text { refrigeration machine, EURO4, R134a } \\
\text { refrigerant, cooling to generic market; GLO } \\
\text { - Transport, freight, sea, transoceanic ship with } \\
\text { reefer, cooling; GLO } \\
\text { Transport, freight, train with reefer, cooling; } \\
\text { GLO }\end{array}$ \\
\hline Melon & - $\quad$ Melon production; $G L O$ & $\begin{array}{l}\text { - Operation, reefer, cooling, 40-foot, high-cube, } \\
\text { R134a as refrigerant; GLO } \\
\text { - Transport, freight, lorry with reefer, cooling; } \\
\text { GLO } \\
\text { - Transport, freight, small lorry with } \\
\text { refrigeration machine, EURO4, R134a } \\
\text { refrigerant, cooling to generic market GLO } \\
\text { - Transport, freight, train with reefer cooling; } \\
\text { GLO }\end{array}$ \\
\hline Pear & - $\quad$ Pear production; $G L O$ & $\begin{array}{l}\text { - Operation, reefer, cooling, } 40-\text {-foot, high-cube, } \\
\text { Rl34a as refrigerant; GLO } \\
\text { - Transport, freight, inland, waterways, barge } \\
\text { with reefer, cooling; GLO } \\
\text { - } \quad \text { Transport, freight, lorry with reefer, cooling; } \\
\text { GLO } \\
\text { - Transport, freight, small lorry with } \\
\text { refrigeration machine, EURO4, RI34a } \\
\text { refrigerant, cooling to generic market; GLO } \\
\text { - Transport, freight, sea, transoceanic ship with } \\
\text { reefer, cooling; GLO } \\
\text { - Transport, freight, train with reefer, cooling; } \\
\text { GLO }\end{array}$ \\
\hline
\end{tabular}




\begin{tabular}{|c|c|c|c|}
\hline Endive & $\begin{array}{l}\text { Assumed as Lettuce as } \\
\text { they belong to the same } \\
\text { family }\end{array}$ & - $\quad$ Lettuce production; $G L O$ & $\begin{array}{l}\text { - Operation, reefer, cooling, } 40-f o o t, \text { high-cube, } \\
\text { Rl34a as refrigerant; GLO } \\
\text { - } \quad \text { Transport, freight, inland, waterways, barge } \\
\text { with reefer, cooling; GLO } \\
\text { - Transport, freight, lorry with reefer, cooling; } \\
\text { GLO } \\
\text { - Transport, freight, small lorry with } \\
\quad \text { refrigeration machine, EURO4, } R 134 \text { a } \\
\quad \text { refrigerant, cooling to generic market; GLO } \\
\text { Transport, freight, sea, transoceanic ship with } \\
\quad \text { reefer, cooling; GLO } \\
\quad \text { Transport, freight, train with reefer, cooling; } \\
\quad \text { GLO }\end{array}$ \\
\hline Chicory & $\begin{array}{l}\text { Assumed as Lettuce as } \\
\text { they belong to the same } \\
\text { family }\end{array}$ & - Lettuce production; $G L O$ & $\begin{array}{ll}\text { - Operation, reefer, cooling, } 40-f o o t, \text { high-cube, } \\
\text { Rl34a as refrigerant; GLO } \\
\text { - } \quad \text { Transport, freight, inland, waterways, barge } \\
\text { with reefer, cooling; GLO } \\
\text { - Transport, freight, lorry with reefer, cooling; } \\
\text { GLO } \\
\text { - Transport, freight, small lorry with } \\
\quad \text { refrigeration machine, EURO4, RI34a } \\
\quad \text { refrigerant, cooling to generic market; GLO } \\
\text { Transport, freight, sea, transoceanic ship with } \\
\quad \text { reefer, cooling; GLO } \\
\quad \text { Transport, freight, train with reefer, cooling; } \\
\quad \text { GLO }\end{array}$ \\
\hline Zucchini & & - Zucchini production; $G L O$ & $\begin{array}{ll}\text { - Operation, reefer, cooling, } 40-f o o t, \text { high-cube, } \\
\text { RI34a as refrigerant; } G L O \\
\text { - Transport, freight, lorry with reefer, cooling; } \\
\text { GLO } \\
\text { - Transport, freight, small lorry with } \\
\text { refrigeration machine, EURO4, R134a } \\
\text { refrigerant, cooling to generic market; GLO } \\
\quad \text { Transport, freight, train with reefer, cooling; } \\
\text { GLO }\end{array}$ \\
\hline Onion & & - $\quad$ Onion production; $G L O$ & $\begin{array}{l}\text { Operation, reefer, cooling, 40-foot, high-cube, } \\
\text { R134a as refrigerant; GLO } \\
\text { Transport, freight, inland, waterways, barge } \\
\text { with reefer, cooling; GLO }\end{array}$ \\
\hline
\end{tabular}




\begin{tabular}{|c|c|c|}
\hline & & $\begin{array}{l}\text { - } \\
\text { Transport, freight, lorry with reefer, cooling; } \\
\text { - } \quad \text { Transport, freight, small lorry with } \\
\text { refrigeration machine, EURO4, R134a } \\
\text { refrigerant, cooling to generic market; GLO } \\
\text { - } \quad \text { Transport, freight, sea, transoceanic ship with } \\
\text { reefer, cooling; GLO } \\
\text { - Transport, freight, train with reefer, cooling; } \\
\text { GLO }\end{array}$ \\
\hline Pepper & - $\quad$ Green bell pepper production; GLO & $\begin{array}{l}\text { - Operation, reefer, cooling, 40-foot, high-cube, } \\
\text { R134a as refrigerant; GLO } \\
\text { - Transport, freight, inland, waterways, barge } \\
\text { with reefer, cooling; GLO } \\
\text { - Transport, freight, lorry with reefer, cooling; } \\
\text { GLO Transport, freight, small lorry with } \\
\text { refrigeration machine, EURO4, R134a } \\
\text { refrigerant, cooling to generic market; GLO } \\
\text { - Transport, freight, sea, transoceanic ship with } \\
\text { reefer, cooling; GLO } \\
\quad \text { Transport, freight, train with reefer, cooling; } \\
\quad \text { GLO }\end{array}$ \\
\hline Grape & - $\quad$ Grape production; $G L O$ & $\begin{array}{l}\text { - Operation, reefer, cooling, 40-foot, high-cube, } \\
\text { R134a as refrigerant; GLO } \\
\text { - Transport, freight, lorry with reefer, cooling; } \\
\text { GLO } \\
\text { - Transport, freight, small lorry with } \\
\text { refrigeration machine, EURO4, R134a } \\
\text { refrigerant, cooling to generic market; GLO } \\
\text { Transport, freight, train with reefer, cooling; } \\
\quad \text { GLO }\end{array}$ \\
\hline Cucumber & - Cucumber production; $G L O$ & $\begin{array}{l}\text { - Operation, reefer, cooling, 40-foot, high-cube, } \\
\text { R134a as refrigerant; GLO } \\
\text { - Transport, freight, lorry with reefer, cooling; } \\
\text { GLO } \\
\text { - Transport, freight, small lorry with } \\
\text { refrigeration machine, EURO4, RI34a } \\
\text { refrigerant, cooling to generic market; GLO } \\
\text { Transport, freight, train with reefer, cooling; } \\
\text { GLO }\end{array}$ \\
\hline Lemon & - Lemon production; $G L O$ & $\begin{array}{l}\text { - Operation, reefer, cooling, 40-foot, high-cube, } \\
\text { Rl34a as refrigerant; GLO } \\
\text { Transport, freight, inland, waterways, barge } \\
\text { with reefer, cooling; GLO }\end{array}$ \\
\hline
\end{tabular}




\begin{tabular}{|c|c|c|c|}
\hline & & & $\begin{array}{l}\text { - } \\
\text { Transport, freight, lorry with reefer, cooling; } \\
\text { - } \quad \text { Transport, freight, small lorry with } \\
\text { refrigeration machine, EURO4, RI34a } \\
\text { refrigerant, cooling to generic market; GLO } \\
\text { - } \\
\text { Transport, freight, sea, transoceanic ship with } \\
\text { reefer, cooling; GLO } \\
\text { - Transport, freight, train with reefer, cooling; } \\
\text { GLO }\end{array}$ \\
\hline Watermelon & $\begin{array}{l}\text { Based on the study by } \\
\text { Shamshirband et al. } \\
\text { (2015) }\end{array}$ & $\begin{array}{l}\text { - } \quad \text { Diesel, burned in agricultural machinery; } \\
\text { GLO } \\
\text { - } \quad \text { Urea ammonium nitrate production; } R \text { RoW } \\
\text { - Electricitity production, natural gas, } \\
\text { - conventional power plant; } \text { RoW } \\
\quad \text { Diammonium phosphate production; } \text { RoW }\end{array}$ & $\begin{array}{l}\text { - Operation, reefer, cooling, } 40-f o o t, \text { high-cube, } \\
\text { Rl34a as refrigerant; GLO } \\
\text { - Transport, freight, inland, waterways, barge } \\
\text { with reefer, cooling; GLO } \\
\text { - Transport, freight, lorry with reefer, cooling; } \\
\text { GLO } \\
\text { - Transport, freight, small lorry with } \\
\text { refrigeration machine, EURO4, R134a } \\
\text { refrigerant, cooling to generic market; GLO } \\
\text { - Transport, freight, sea, transoceanic ship with } \\
\text { reefer, cooling; GLO } \\
\text { - Transport, freight, train with reefer, cooling; } \\
\text { GLO }\end{array}$ \\
\hline Pomelo & $\begin{array}{l}\text { Assumed as Lemon as } \\
\text { they belong to the same } \\
\text { family }\end{array}$ & - Lemon production; GLO & $\begin{array}{ll}\text { - Operation, reefer, cooling, } 40-f o o t, \text { high-cube, } \\
\text { RI34a as refrigerant; GLO } \\
\text { - Transport, freight, inland, waterways, barge } \\
\text { with reefer, cooling; GLO } \\
\text { - Transport, freight, lorry with reefer, cooling; } \\
\quad \text { GLO } \\
\quad \text { Transport, freight, small lorry with } \\
\text { refrigeration machine, EURO4, RI34a } \\
\text { refrigerant, cooling to generic market; GLO } \\
\text { Transport, freight, sea, transoceanic ship with } \\
\text { reefer, cooling; GLO } \\
\quad \text { Transport, freight, train with reefer, cooling; } \\
\text { GLO }\end{array}$ \\
\hline Kiwi & & - Kiwi production; $G L O$ & $\begin{array}{l}\text { - Operation, reefer, cooling, 40-foot, high-cube, } \\
\text { Rl34a as refrigerant; GLO } \\
\text { - Transport, freight, inland, waterways, barge } \\
\text { with reefer, cooling; GLO } \\
\text { Transport, freight, lorry with reefer, cooling; } \\
\text { GLO }\end{array}$ \\
\hline
\end{tabular}




\begin{tabular}{|c|c|c|c|}
\hline & & & 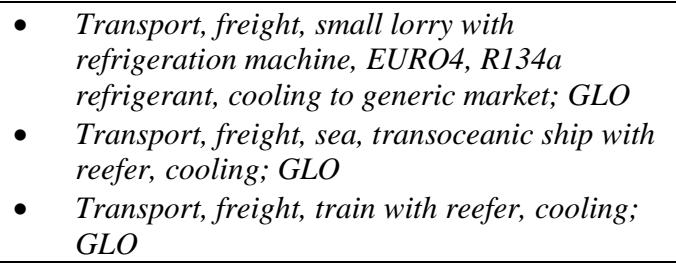 \\
\hline Strawberry & & $\begin{array}{l}\text { - Strawberry production, open field, macro } \\
\text { tunnel; RoW }\end{array}$ & $\begin{array}{l}\text { - Operation, reefer, cooling, 40-foot, high-cube, } \\
\text { Rl34a as refrigerant; GLO } \\
\text { - } \quad \text { Transport, freight, aircraft with reefer, cooling; } \\
\text { GLO } \\
\text { - Transport, freight, lorry with reefer, cooling, } \\
\quad \text { GLO } \\
\text { - Transport, freight, small lorry with } \\
\text { refrigeration machine, EURO4, } R 134 \text { a } \\
\text { refrigerant, cooling to generic market; GLO } \\
\quad \text { Transport, freight, train with reefer, cooling } \\
\text { GLO }\end{array}$ \\
\hline Leek & $\begin{array}{l}\text { Assumed as Onion as } \\
\text { they belong to the same } \\
\text { family }\end{array}$ & - Onion production; $G L O$ & $\begin{array}{l}\text { - Operation, reefer, cooling, 40-foot, high-cube, } \\
\text { Rl34a as refrigerant; GLO } \\
\text { - Transport, freight, inland, waterways, barge } \\
\text { with reefer, cooling; GLO } \\
\text { - Transport, freight, lorry with reefer, cooling; } \\
\text { GLO } \\
\text { - Transport, freight, small lorry with } \\
\text { refrigeration machine, EURO4, R134a } \\
\text { refrigerant, cooling to generic market; GLO } \\
\text { - Transport, freight, sea, transoceanic ship with } \\
\text { reefer, cooling; GLO } \\
\text { - Transport, freight, train with reefer, cooling; } \\
\quad \text { GLO }\end{array}$ \\
\hline Avocado & & - Avocado production; $G L O$ & $\begin{array}{l}\text { Operation, reefer, cooling, 40-foot, high-cube, } \\
\text { R134a as refrigerant; GLO } \\
\text { Transport, freight, lorry with reefer, cooling; } \\
\text { GLO } \\
\text { Transport, freight, small lorry with } \\
\text { refrigeration machine, EURO4, R134a } \\
\text { refrigerant, cooling to generic market GLO } \\
\text { Transport, freight, train with reefer cooling; } \\
\text { GLO }\end{array}$ \\
\hline Apricot & & - Apricot production; $R$ RoW & $\begin{array}{l}\text { - Operation, reefer, cooling, 40-foot, high-cube, } \\
\text { R134a as refrigerant; GLO }\end{array}$ \\
\hline
\end{tabular}




\begin{tabular}{|c|c|c|c|}
\hline & & & $\begin{array}{l}\text { - } \text { Transport, freight, inland, waterways, barge } \\
\text { with reefer, cooling; GLO } \\
\text { - Transport, freight, lorry with reefer, cooling; } \\
\text { GLO } \\
\text { Transport, freight, small lorry with } \\
\text { refrigeration machine, EURO4, R134a } \\
\text { refrigerant, cooling to generic market; GLO } \\
\text { Transport, freight, sea, transoceanic ship with } \\
\text { reefer, cooling; GLO } \\
\quad \text { Transport, freight, train with reefer, cooling; } \\
\text { GLO }\end{array}$ \\
\hline Plum & $\begin{array}{l}\text { Assumed as Pear as they } \\
\text { belong to the same } \\
\text { family }\end{array}$ & - $\quad$ Pear production; $G L O$ & 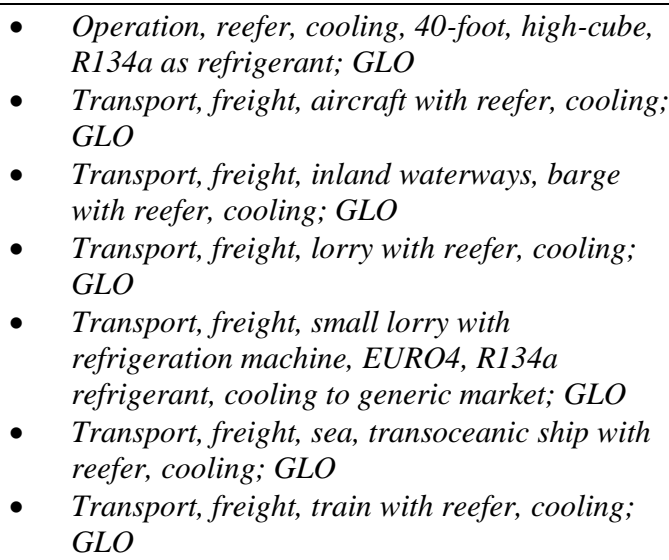 \\
\hline Beetroot & $\begin{array}{l}\text { Assumed as Spinach as } \\
\text { they belong to the same } \\
\text { family }\end{array}$ & - Spinach production; $G L O$ & $\begin{array}{l}\text { Operation, reefer, cooling, } 40-\text {-foot, high-cube, } \\
\text { R134a as refrigerant; GLO } \\
\text { Transport, freight, lorry with reefer, cooling; } \\
\text { GLO } \\
\text { - } \text { Transport, freight, small lorry with } \\
\text { refrigeration machine, EURO4, RI34a } \\
\text { refrigerant, cooling to generic market GLO } \\
\text { Transport, freight, train with reefer cooling; } \\
\text { GLO }\end{array}$ \\
\hline Champignon & $\begin{array}{l}\text { Assumed as Apple as no } \\
\text { other information was } \\
\text { available }\end{array}$ & - Apple production; $G L O$ & $\begin{array}{l}\text { Operation, reefer, cooling, 40-foot, high-cube, } \\
\text { RI34a as refrigerant; GLO } \\
\text { Transport, freight, inland, waterways, barge } \\
\text { with reefer, cooling; GLO } \\
\text { Transport, freight, lorry with reefer, cooling; } \\
\text { GLO }\end{array}$ \\
\hline
\end{tabular}




\begin{tabular}{|c|c|c|c|}
\hline & & & 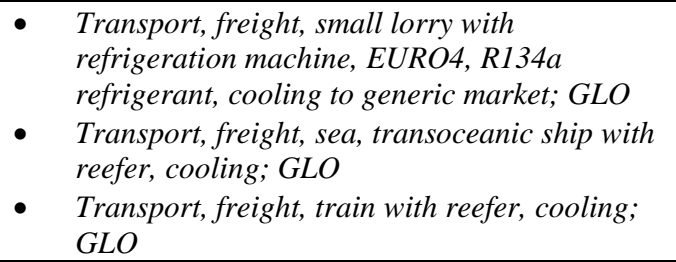 \\
\hline Pineapple & & - $\quad$ Pineapple production; $G L O$ & 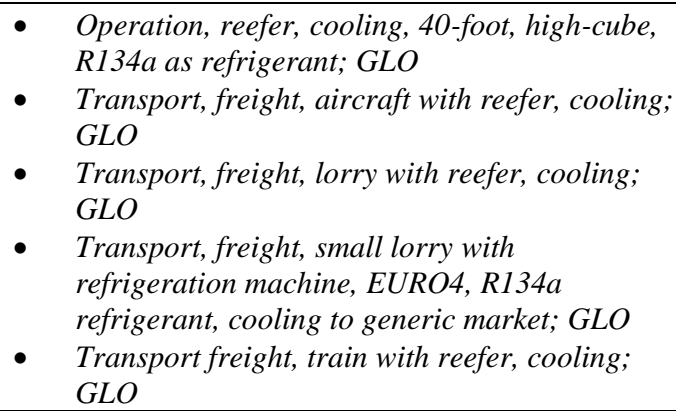 \\
\hline Cauliflower & & - Cauliflower production; GLO & 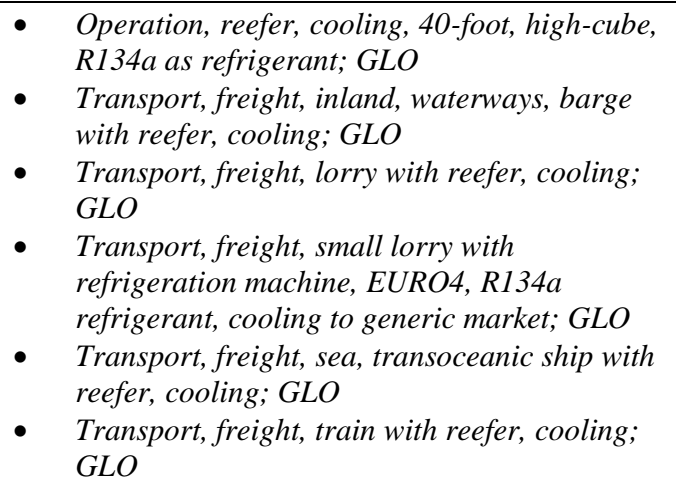 \\
\hline Artichoke & $\begin{array}{l}\text { Assumed as Lettuce as } \\
\text { they belong to the same } \\
\text { family }\end{array}$ & - $\quad$ Lettuce production; $G L O$ & $\begin{array}{l}\text { - Operation, reefer, cooling, 40-foot, high-cube, } \\
\text { Rl34a as refrigerant; GLO } \\
\text { - Transport, freight, inland, waterways, barge } \\
\text { with reefer, cooling; GLO } \\
\text { Transport, freight, lorry with reefer, cooling; } \\
\text { GLO } \\
\text { - Transport, freight, small lorry with } \\
\text { refrigeration machine, EURO4, RI34a } \\
\text { refrigerant, cooling to generic market; GLO } \\
\text { Transport, freight, sea, transoceanic ship with } \\
\text { reefer, cooling; GLO }\end{array}$ \\
\hline
\end{tabular}




\begin{tabular}{|c|c|c|c|}
\hline & & & $\begin{array}{l}\text { - Transport, freight, train with reefer, cooling; } \\
\text { GLO }\end{array}$ \\
\hline Celeriac & $\begin{array}{l}\text { Assumed as Carrot as } \\
\text { they belong to the same } \\
\text { family }\end{array}$ & - Carrot production; $G L O$ & $\begin{array}{l}\text { - Operation, reefer, cooling, } 40-\text {-foot, high-cube, } \\
\text { R134a as refrigerant; GLO } \\
\text { - Transport, freight, inland, waterways, barge } \\
\text { with reefer, cooling; GLO } \\
\text { - Transport, freight, lorry with reefer, cooling; } \\
\quad \text { GLO } \\
\text { - Transport, freight, small lorry with } \\
\text { refrigeration machine, EURO4, R134a } \\
\text { refrigerant, cooling to generic market; GLO } \\
\text { Transport, freight, sea, transoceanic ship with } \\
\text { reefer, cooling; GLO } \\
\text { - Transport, freight, train with reefer, cooling; } \\
\quad \text { GLO }\end{array}$ \\
\hline $\begin{array}{l}\text { Savoy } \\
\text { cabbage }\end{array}$ & $\begin{array}{l}\text { Assumed as Cauliflower } \\
\text { as they belong to the } \\
\text { same family }\end{array}$ & - $\quad$ Cauliflower production; $G L O$ & 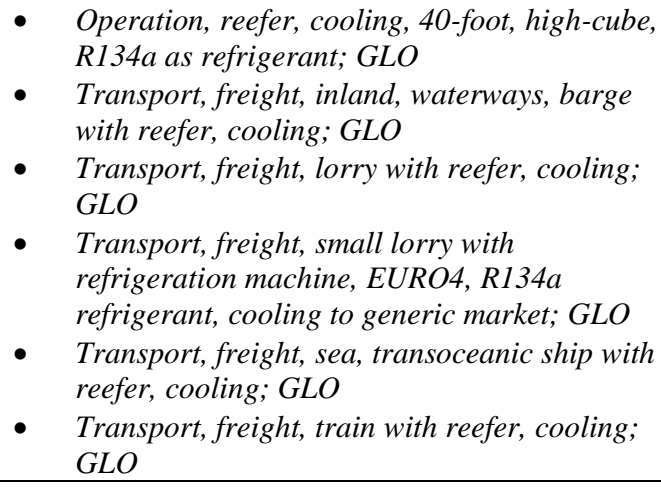 \\
\hline Radish & & - Radish production; $G L O$ & $\begin{array}{l}\text { - Operation, reefer, cooling, } 40 \text {-foot, high-cube, } \\
\text { Rl34a as refrigerant; GL } \\
\text { - Transport, freight, inland, waterways, barge } \\
\text { with reefer, cooling; GLO } \\
\text { - Transport, freight, lorry with reefer, cooling; } \\
\text { GLO } \\
\text { - Transport, freight, small lorry with } \\
\text { refrigeration machine, EURO4, RI34a } \\
\text { refrigerant, cooling to generic market; GLO } \\
\text { - Transport, freight, sea, transoceanic ship with } \\
\text { reefer, cooling; GLO } \\
\text { - Transport, freight, train with reefer, cooling; } \\
\text { GLO }\end{array}$ \\
\hline
\end{tabular}




\begin{tabular}{|c|c|c|c|}
\hline Walnut & $\begin{array}{l}\text { Assumed as Apple as no } \\
\text { other information was } \\
\text { available }\end{array}$ & - Apple production; GLO & $\begin{array}{l}\text { - Operation, reefer, cooling, } 40-f o o t, \text { high-cube, } \\
\text { Rl34a as refrigerant; GLO } \\
\text { - Transport, freight, inland, waterways, barge } \\
\text { with reefer, cooling; GLO } \\
\text { - Transport, freight, lorry with reefer, cooling; } \\
\text { GLO } \\
\text { - Transport, freight, small lorry with } \\
\text { refrigeration machine, EURO4, RI34a } \\
\text { refrigerant, cooling to generic market; GLO } \\
\text { - Transport, freight, sea, transoceanic ship with } \\
\text { reefer, cooling; GLO } \\
\text { Transport, freight, train with reefer, cooling; } \\
\text { GLO }\end{array}$ \\
\hline Broccoli & & - Broccoli production; $G L O$ & 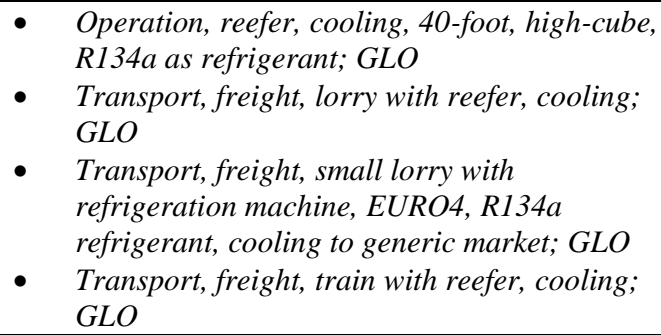 \\
\hline Pumpkin & $\begin{array}{l}\text { Assumed as Melon as } \\
\text { they belong to the same } \\
\text { family }\end{array}$ & - $\quad$ Melon production; $G L O$ & 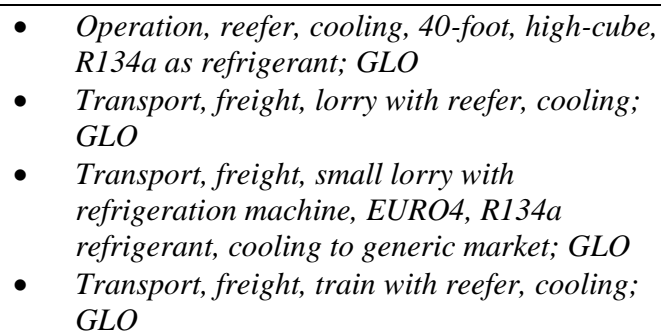 \\
\hline Shallot & $\begin{array}{l}\text { Assumed as Onion as } \\
\text { they belong to the same } \\
\text { family }\end{array}$ & - Onion production; $G L O$ & $\begin{array}{l}\text { - Operation, reefer, cooling, } 40 \text {-foot, high-cube, } \\
\text { RI34a as refrigerant; GLO } \\
\text { - Transport, freight, inland, waterways, barge } \\
\text { with reefer, cooling; GLO } \\
\text { - Transport, freight, lorry with reefer, cooling; } \\
\quad \text { GLO } \\
\text { - Transport, freight, small lorry with } \\
\text { refrigeration machine, EURO4, RI34a } \\
\text { refrigerant, cooling to generic market; GLO } \\
\text { - Transport, freight, sea, transoceanic ship with } \\
\text { reefer, cooling; GLO }\end{array}$ \\
\hline
\end{tabular}




\begin{tabular}{|c|c|c|c|}
\hline & & & $\begin{array}{l}\text { - Transport, freight, train with reefer, cooling; } \\
\text { GLO }\end{array}$ \\
\hline Celery & & - $\quad$ Celery 675 production; $G L O$ & $\begin{array}{l}\text { - Operation, reefer, cooling, } 40-\text {-foot, high-cube, } \\
\text { Rl34a as refrigerant; GLO } \\
\text { - Transport, freight, inland, waterways, barge } \\
\text { with reefer, cooling; GLO } \\
\text { - Transport, freight, lorry with reefer, cooling; } \\
\text { GLO } \\
\text { - Transport, freight, small lorry with } \\
\text { refrigeration machine, EURO4, RI34a } \\
\text { refrigerant, cooling to generic market; GLO } \\
\text { - Transport, freight, sea, transoceanic ship with } \\
\text { reefer, cooling; GLO } \\
\text { Transport, freight, train with reefer, cooling; } \\
\text { GLO }\end{array}$ \\
\hline Aubergine & & - $\quad$ Aubergine production, $G L O$ & $\begin{array}{l}\text { - Operation, reefer, cooling, 40-foot, high-cube, } \\
\text { Rl34a as refrigerant; GLO } \\
\text { - Transport, freight, lorry with reefer, cooling; } \\
\text { GLO } \\
\text { - Transport, freight, small lorry with } \\
\text { refrigeration machine, EURO4, RI34a } \\
\text { refrigerant, cooling to generic market; GLO } \\
\quad \text { Transport, freight, train with reefer, cooling; } \\
\text { GLO }\end{array}$ \\
\hline Valerian & $\begin{array}{l}\text { Assumed as Lettuce as } \\
\text { they are both salad }\end{array}$ & - Lettuce production; $G L O$ & $\begin{array}{l}\text { - Operation, reefer, cooling, } 40 \text {-foot, high-cube, } \\
\text { R134a as refrigerant; GLO } \\
\text { - Transport, freight, inland, waterways, barge } \\
\text { with reefer, cooling; GLO } \\
\text { Transport, freight, lorry with reefer, cooling; } \\
\text { GLO } \\
\text { - Transport, freight, small lorry with } \\
\text { refrigeration machine, EURO4, R134a } \\
\text { refrigerant, cooling to generic market; GLO } \\
\text { Transport, freight, sea, transoceanic ship with } \\
\text { reefer, cooling; GLO } \\
\text { Transport, freight, train with reefer, cooling; } \\
\text { GLO }\end{array}$ \\
\hline Asparagus & & - Green asparagus production; $G L O$ & $\begin{array}{l}\text { Operation, reefer, cooling, 40-foot, high-cube, } \\
\text { R134a as refrigerant; GLO } \\
\text { Transport, freight, aircraft with reefer, cooling; } \\
\text { GLO }\end{array}$ \\
\hline
\end{tabular}




\begin{tabular}{|c|c|c|c|}
\hline & & & $\begin{array}{l}\text { - Transport, freight, inland waterways, barge } \\
\text { with reefer, cooling; GLO } \\
\text { - Transport, freight, lorry with reefer, cooling; } \\
\text { GLO } \\
\text { Transport, freight, small lorry with } \\
\text { refrigeration machine, EURO4, RI34a } \\
\text { refrigerant, cooling to generic market; GLO } \\
\text { Transport, freight, sea, transoceanic ship with } \\
\text { reefer, cooling; GLO } \\
\text { Transport, freight, train with reefer, cooling; } \\
\text { GLO }\end{array}$ \\
\hline Chestnuts & $\begin{array}{l}\text { Based on the study by } \\
\text { Rosa et al. (2016) }\end{array}$ & $\begin{array}{l}\text { - Urea ammonium nitrate production; } R o W \\
\text { - } \quad \text { Potassium chloride production; } R \text { oW } \\
\text { - } \quad \text { Lime to generium phosphate production; } \text { ROW } \\
\text { agent; GLO } \\
\text { - Diesel, burned in agricultural machinery; } \\
\quad \text { GLO } \\
\text { - } \quad \text { Getrol, unleaded, burned in machinery; } \\
\quad\end{array}$ & $\begin{array}{l}\text { - Operation, reefer, cooling, 40-foot, high-cube, } \\
\text { R134a as refrigerant; GLO } \\
\text { - Transport, freight, inland, waterways, barge } \\
\text { with reefer, cooling; GLO } \\
\text { - Transport, freight, lorry with reefer, cooling; } \\
\quad \text { GLO } \\
\text { - Transport, freight, small lorry with } \\
\text { refrigeration machine, EURO4, R134a } \\
\text { refrigerant, cooling to generic market; GLO } \\
\text { - Transport, freight, sea, transoceanic ship with } \\
\text { reefer, cooling; GLO } \\
\text { - Transport, freight, train with reefer, cooling; } \\
\text { GLO }\end{array}$ \\
\hline Spinach & & - Spinach production; $G L O$ & $\begin{array}{l}\text { - Operation, reefer, cooling, } 40 \text {-foot, high-cube, } \\
\text { R134a as refrigerant; GLO } \\
\text { - } \quad \text { Transport, freight, lorry with reefer, cooling; } \\
\text { GLO } \\
\text { - } \\
\text { Transport, freight, small lorry with } \\
\text { refrigeration machine, EURO4, R134a } \\
\text { refrigerant, cooling to generic market GLO } \\
\text { - Transport, freight, train with reefer cooling; } \\
\text { GLO }\end{array}$ \\
\hline Cherry & $\begin{array}{l}\text { Assumed as Apple as } \\
\text { they belong to the same } \\
\text { family }\end{array}$ & - Apple production; $G L O$ & $\begin{array}{l}\text { - } \quad \text { Operation, reefer, cooling, } 40 \text {-foot, high-cube, } \\
\text { R134a as refrigerant; GL } \\
\text { - } \quad \text { Transport, freight, inland, waterways, barge } \\
\text { with reefer, cooling; GLO } \\
\text { - } \\
\quad \text { Gransport, freight, lorry with reefer, cooling; } \\
\text { - } \quad \text { Transport, freight, small lorry with } \\
\text { refrigeration machine, EURO4, R134a } \\
\text { refrigerant, cooling to generic market; GLO }\end{array}$ \\
\hline
\end{tabular}




\begin{tabular}{|c|c|c|c|}
\hline & & & $\begin{array}{l}\text { - Transport, freight, sea, transoceanic ship with } \\
\text { reefer, cooling; GLO } \\
\text { Transport, freight, train with reefer, cooling; } \\
\text { GLO }\end{array}$ \\
\hline Green beans & $\begin{array}{l}\text { Assumed as Peas as they } \\
\text { belong to the same } \\
\text { family }\end{array}$ & - $\quad$ Protein pea production; $G L O$ & $\begin{array}{l}\text { - } \quad \text { Transport, freight train; } F R \\
\text { - } \\
\quad \text { Transport, fright, inland waterways, barge; } \\
\text { - } \\
\quad \text { Transport, freight, lorry, all sizes, EURO4 to } \\
\text { generic market for } \\
\text { - } \\
\text { - Transport, freight, lorry unspecified; } \text { RoW } \\
\end{array}$ \\
\hline Fennel & & - Fennel production; $G L O$ & $\begin{array}{l}\text { Operation, reefer, cooling, } 40-\text {-foot, high-cube, } \\
\text { R134a as refrigerant; GLO } \\
\text { Transport, freight, lorry with reefer, cooling; } \\
\text { GLO } \\
\quad \text { Transport, freight, small lorry with } \\
\text { refrigeration machine, EURO4, R134a } \\
\quad \text { refrigerant, cooling to generic market; GLO } \\
\quad \text { Transport, freight, train with reefer, cooling; } \\
\text { GLO }\end{array}$ \\
\hline Turnip & $\begin{array}{l}\text { Assumed as Radish as } \\
\text { they belong to the same } \\
\text { family }\end{array}$ & - $\quad$ Radish production; GLO & $\begin{array}{l}\text { - Operation, reefer, cooling, } 40-\text {-foot, high-cube, } \\
\text { Rl34a as refrigerant; GLO } \\
\text { - Transport, freight, inland, waterways, barge } \\
\text { with reefer, cooling; GLO } \\
\text { - Transport, freight, lorry with reefer, cooling; } \\
\text { GLO } \\
\text { - Transport, freight, small lorry with } \\
\text { refrigeration machine, EURO4, RI34a } \\
\text { refrigerant, cooling to generic market; GLO } \\
\text { - Transport, freight, sea, transoceanic ship with } \\
\text { reefer, cooling; GLO } \\
\text { - Transport, freight, train with reefer, cooling; } \\
\text { GLO }\end{array}$ \\
\hline $\begin{array}{l}\text { Brussels } \\
\text { sprouts }\end{array}$ & $\begin{array}{l}\text { Assumed as Broccoli as } \\
\text { they belong to the same } \\
\text { family }\end{array}$ & - Broccoli production; $G L O$ & $\begin{array}{l}\text { - Operation, reefer, cooling, 40-foot, high-cube, } \\
\text { R134a as refrigerant; GLO } \\
\text { - Transport, freight, lorry with reefer, cooling; } \\
\text { GLO } \\
\text { Transport, freight, small lorry with } \\
\text { refrigeration machine, EURO4, R134a } \\
\text { refrigerant, cooling to generic market; GLO } \\
\text { Transport, freight, train with reefer, cooling; } \\
\text { GLO }\end{array}$ \\
\hline
\end{tabular}




\begin{tabular}{|c|c|c|c|c|}
\hline & Peas & & - $\quad$ Protein pea production; $G L O$ & 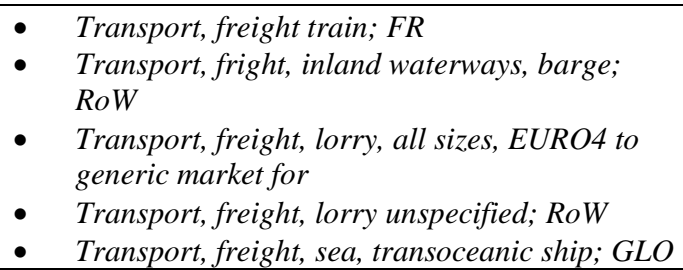 \\
\hline \multirow{6}{*}{ Poultry } & Chicken & $\begin{array}{l}\text { Assumed on information } \\
\text { provided by LCA food } \\
\text { DK } \quad(2-0 \quad \text { LCA } \\
\text { Consultants, 2007) }\end{array}$ & 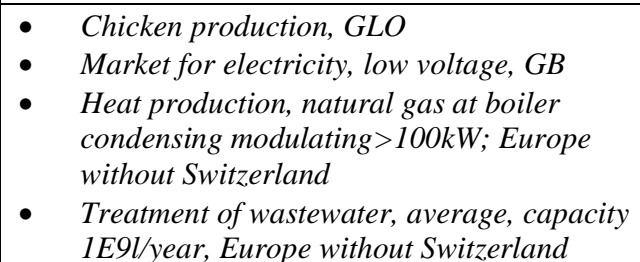 & $\begin{array}{l}\text { Transport, freight, lorry, all sizes, EURO } 4 \text { to } \\
\text { generic market for transport, freight, lorry, } \\
\text { unspecified; RoW }\end{array}$ \\
\hline & $\begin{array}{c}\text { Elaborated } \\
\text { poultry }\end{array}$ & Assumed as Chicken & - Chicken $^{4}$ & $\begin{array}{l}\text { - Transport, freight, lorry, all sizes, EURO } 4 \text { to } \\
\text { generic market for transport, freight, lorry, } \\
\text { unspecified; RoW }\end{array}$ \\
\hline & Turkey & Assumed as Chicken & - Chicken $^{4}$ & $\begin{array}{l}\text { - Transport, freight, lorry, all sizes, EURO } 4 \text { to } \\
\text { generic market for transport, freight, lorry, } \\
\text { unspecified; RoW }\end{array}$ \\
\hline & Other poultry & Assumed as Chicken & - $\quad$ Chicken $^{4}$ & $\begin{array}{l}\text { - Transport, freight, lorry, all sizes, EURO } 4 \text { to } \\
\text { generic market for transport, freight, lorry, } \\
\text { unspecified; RoW }\end{array}$ \\
\hline & Duck & Assumed as Chicken & - $\quad$ Chicken $^{4}$ & $\begin{array}{l}\text { - Transport, freight, lorry, all sizes, EURO } 4 \text { to } \\
\text { generic market for transport, freight, lorry, } \\
\text { unspecified; RoW }\end{array}$ \\
\hline & Fresh rabbit & Assumed as Chicken & - $\quad$ Chicken $^{4}$ & $\begin{array}{l}\text { - Transport, freight, lorry, all sizes, EURO } 4 \text { to } \\
\text { generic market for transport, freight, lorry, } \\
\text { unspecified; RoW }\end{array}$ \\
\hline \multirow{2}{*}{ Meat } & Fresh pork & $\begin{array}{l}\text { Assumed on information } \\
\text { provided by LCA food } \\
\text { DK (2-0 LCA } \\
\text { Consultants, 2007) }\end{array}$ & 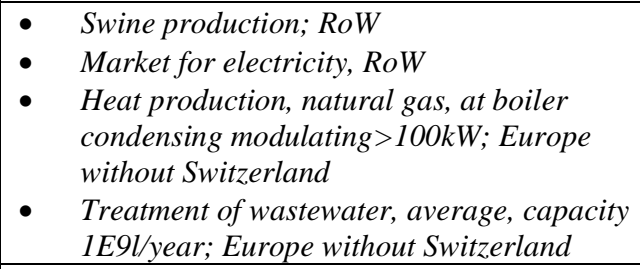 & $\begin{array}{l}\text { Transport, freight, lorry, all sizes, EURO } 4 \text { to } \\
\text { generic market for transport, freight, lorry, } \\
\text { unspecified; RoW }\end{array}$ \\
\hline & Beef & $\begin{array}{l}\text { Assumed on information } \\
\text { provided by LCA food } \\
\text { DK (2-0 LCA } \\
\text { Consultants, 2007) }\end{array}$ & $\begin{array}{l}\text { - Cattle for slaughtering, live weight to } \\
\text { generic market for red meat, live weight; } \\
\text { GLO } \\
\text { Market for electricity, low voltage, GB } \\
\text { - Heat production, natural gas, at boiler } \\
\text { condensing modulating }>100 \mathrm{~kW} \text {; Europe } \\
\text { without Switzerland }\end{array}$ & $\begin{array}{l}\text { - } \quad \text { Transport, freight, aircraft, intracontinental; } \\
\text { RoW } \\
\text { Transport, freight, lorry, all sizes, EURO4 to } \\
\text { generic market for transport, freight, lorry, } \\
\text { unspecified; RoW }\end{array}$ \\
\hline
\end{tabular}




\begin{tabular}{|c|c|c|c|c|}
\hline & & & $\begin{array}{l}\text { - Treatment of wastewater, average, capacity } \\
\text { 1E9l/year; Europe without Switzerland }\end{array}$ & \\
\hline & $\begin{array}{l}\text { Other } \\
\text { elaborated }\end{array}$ & Assumed as Pork & - $\quad$ Swine $^{2}$ & $\begin{array}{l}\text { Transport, freight, lorry, all sizes, EURO } 4 \text { to } \\
\text { generic market for transport, freight, lorry, } \\
\text { unspecified; RoW }\end{array}$ \\
\hline & $\begin{array}{l}\text { Fresh minced } \\
\text { meat }\end{array}$ & Assumed as Pork & - $\quad$ Swine $^{2}$ & $\begin{array}{l}\text { - Transport, freight, lorry, all sizes, EURO } 4 \text { to } \\
\text { generic market for transport, freight, lorry, } \\
\text { unspecified; RoW }\end{array}$ \\
\hline & Veal & Assumed as Beef & - $\quad$ Cattle $^{l}$ & $\begin{array}{l}\text { - } \quad \text { Transport, freight, aircraft, intracontinental; } \\
\text { RoW } \\
\text { - Transport, freight, lorry, all sizes, EURO4 to } \\
\text { generic market for transport, freight, lorry, } \\
\text { unspecified; RoW }\end{array}$ \\
\hline & Ovine & $\begin{array}{l}\text { Assumed on information } \\
\text { provided by LCA food } \\
\text { DK } \quad(2-0 \quad \text { LCA } \\
\text { Consultants, 2007) }\end{array}$ & $\begin{array}{l}\text { - } \quad \text { Sheep for slaughtering, live weight to } \\
\text { generic market for red meat, live weight, } \\
\text { GLO } \\
\text { - } \quad \text { Market for electricity, low voltage, GB } \\
\text { - Heat production, natural gas, at boiler } \\
\text { condensing modulating }>100 \mathrm{~kW} \text {; Europe } \\
\text { without Switzerland } \\
\text { Treatment of wastewater, average, capacity } \\
\text { 1E9l/year; Europe without Switzerland }\end{array}$ & $\begin{array}{l}\text { - Transport, freight, lorry, all sizes, EURO4 to } \\
\text { generic market for transport, freight, lorry, } \\
\text { unspecified; RoW }\end{array}$ \\
\hline & Offal of meat & Assumed as Pork & - $\quad$ Swine $^{2}$ & $\begin{array}{l}\text { - Transport, freight, lorry, all sizes, EURO } 4 \text { to } \\
\text { generic market for transport, freight, lorry, } \\
\text { unspecified; RoW }\end{array}$ \\
\hline & Horse & Assumed as Beef & - $\quad$ Cattle $^{l}$ & $\begin{array}{l}\text { - Transport, freight, aircraft, intracontinental; } \\
\text { RoW } \\
\text { - Transport, freight, lorry, all sizes, EURO4 to } \\
\text { generic market for transport, freight, lorry, } \\
\text { unspecified; RoW }\end{array}$ \\
\hline Cheese & Cheese & & $\begin{array}{l}\text { - Cheese production, soft, from cow milk; } \\
\text { GLO }\end{array}$ & $\begin{array}{ll}\text { - } & \text { Transport; freight train; FR } \\
\text { - } & \text { Transport, freight, light commerical vehicle; } \\
& \text { RoW } \\
\text { - } & \text { Transport, freight, lorry, all sizes, EURO4 to } \\
& \text { generic market for transport, freight, lorry, } \\
& \text { unspecified; } \text { RoW } \\
\text { - } & \text { Transport, freight, sea, transoceanic ship; GLO }\end{array}$ \\
\hline
\end{tabular}




\begin{tabular}{|c|c|c|c|c|}
\hline Gourmet & Gourmet & $\begin{array}{l}\text { Assumed as Production } \\
\text { of pastry }\end{array}$ & $\begin{array}{ll} & \text { Tap water production, conventional } \\
& \text { treatment; RoW } \\
\text { - } & \text { Milk production, from cow; RoW } \\
\text { - } & \text { Beet sugar production; RoW } \\
\text { - } & \text { Butter production, from cow milk; GLO } \\
\text { - } & \text { Heat production, natural gas, at industrial } \\
& \text { furnace > } 100 \mathrm{~kW} ; \text { RoW } \\
\text { - } & \text { Petrol. Unleaded, burned in machinery; } \\
& \text { GLO } \\
\text { - } & \text { Electricity production, natural gas, } \\
& \text { conventional power plant; RoW } \\
\text { - } & \text { Wheat flour; GLO } \\
\text { - } & \text { Chicken } \\
\end{array}$ & $\begin{array}{ll}\text { - } & \text { Transport, freight train; FR } \\
\text { - } & \text { Transport freight inland waterways, barge; } \\
\text { RoW } \\
\text { - } \\
\text { Transport, freight, lorry, all sizes, EURO4 to } \\
\text { generic market for transport, freight, lorry, } \\
\text { unspecified; RoW } \\
\text { - Transport, freight, sea, transoceanic ship; GLO }\end{array}$ \\
\hline \multirow[t]{2}{*}{ Pastry } & $\begin{array}{l}\text { Pastries and } \\
\text { cakes }\end{array}$ & $\begin{array}{l}\text { Estimated on a mix of } \\
\text { ingredients based on Paul } \\
\text { Holliwood (2017). The } \\
\text { energy consumption is } \\
\text { based on Masanet et al. } \\
\text { (2012). }\end{array}$ & 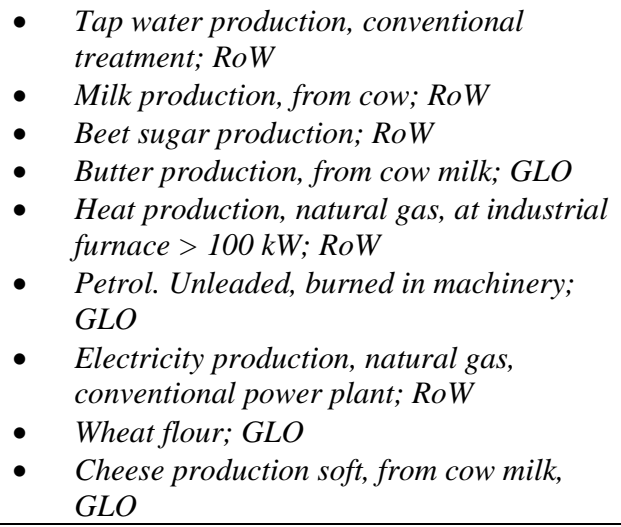 & $\begin{array}{ll}\text { - } & \text { Transport, freight train; FR } \\
\text { - } & \text { Transport freight inland waterways, barge; } \\
\text { RoW } \\
\text { - } \\
\text { Transport, freight, lorry, all sizes, EURO4 to } \\
\text { generic market for transport, freight, lorry, } \\
\text { unspecified; RoW } \\
\text { - Transport, freight, sea, transoceanic ship; GLO }\end{array}$ \\
\hline & Croissants & $\begin{array}{l}\text { Estimated on a mix of } \\
\text { ingredients based on } \\
\text { ChefSteps (2017). The } \\
\text { energy consumption is } \\
\text { based on Masanet et al. } \\
\text { (2012). }\end{array}$ & 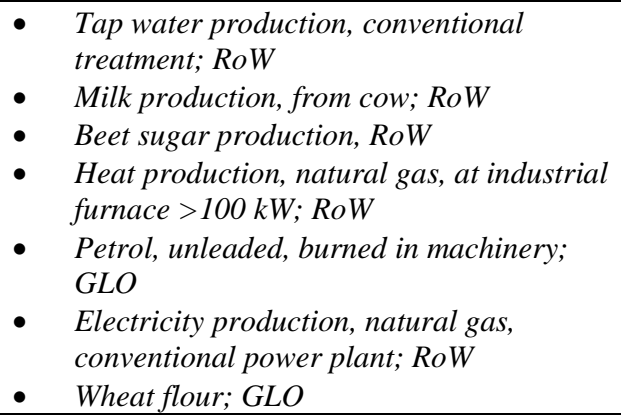 & $\begin{array}{l}\text { - } \quad \text { Transport, freight train; FR } \\
\text { - Transport freight inland waterways, barge; } \\
\text { RoW } \\
\text { - Transport, freight, lorry, all sizes, EURO4 to } \\
\text { generic market for transport, freight, lorry, } \\
\text { unspecified; RoW } \\
\text { - Transport, freight, sea, transoceanic ship; GLO }\end{array}$ \\
\hline Bakery & Bread & $\begin{array}{l}\text { Based on LCA food DK } \\
\text { "Bread, wheat, } \\
\text { conventional fresh" (2-0 } \\
\text { LCA Consultants, 2007). }\end{array}$ & $\begin{array}{l}\text { - } \quad \text { Drinking water from groundwater, RER, } \\
\text { ELCD 2005-corrected Wheat flour: GLO } \\
\text { - } \quad \text { Market for electricity, low voltage; GB }\end{array}$ & $\begin{array}{l}\text { - Transport, freight train; } F R \\
\text { - Transport freight inland waterways, barge; } \\
\text { RoW }\end{array}$ \\
\hline
\end{tabular}




\begin{tabular}{|c|c|c|c|c|}
\hline & & & $\begin{array}{l}\text { - Heat production, natural gas, at boiler fan } \\
\text { burner low-NOx non-modulating }>100 \mathrm{~kW} \text {; } \\
\text { Europe without Switzerland } \\
\text { - Heat production, at hard coal industrial } \\
\text { furnace 1-10MW, Europe without } \\
\text { Switzerland } \\
\text { - Heat production, heavy fuel oil, at } \\
\text { industrial furnace } 1 M W, \text { Europe without } \\
\text { Switzerland }\end{array}$ & $\begin{array}{l}\text { - Transport, freight, lorry, all sizes, EURO4 to } \\
\text { generic market for transport, freight, lorry, } \\
\text { unspecified; RoW } \\
\text { - Transport, freight, sea, transoceanic ship; GLO }\end{array}$ \\
\hline \multirow[t]{2}{*}{ Fish } & Fish & $\begin{array}{l}\text { Assumed on information } \\
\text { provided by LCA food } \\
\text { DK (2-0 LCA } \\
\text { Consultants, 2007) }\end{array}$ & 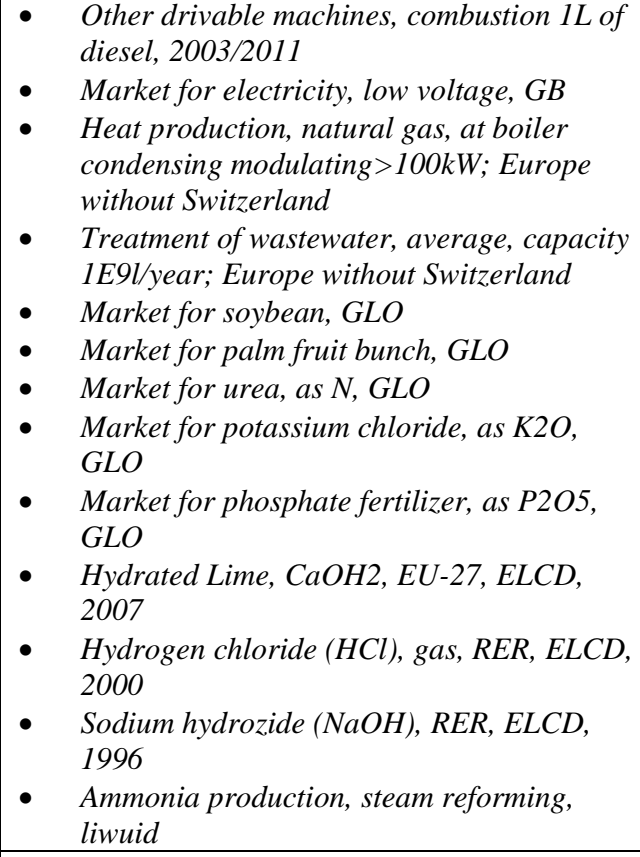 & $\begin{array}{l}\text { - Transport, freight, lorry, all sizes, EURO } 4 \text { to } \\
\text { generic market for transport, freight, lorry, } \\
\text { unspecified; RoW }\end{array}$ \\
\hline & $\begin{array}{l}\text { Shellfish and } \\
\text { molluscs }\end{array}$ & Assumed as Fish & - Fish $^{5}$ & $\begin{array}{l}\text { - Transport, freight, lorry, all sizes, EURO } 4 \text { to } \\
\text { generic market for transport, freight, lorry, } \\
\text { unspecified; RoW }\end{array}$ \\
\hline Liquids & Water & & $\begin{array}{l}\text { - Tap water production, conventional } \\
\text { treatment, } R o W\end{array}$ & $\begin{array}{l}\text { - Operation, reefer, cooling, 40-foot, high-cube, } \\
\text { R134a as refrigerant; GLO } \\
\text { Transport, freight, inland, waterways, barge } \\
\text { with reefer, cooling; GLO } \\
\text { - Transport, freight, lorry with reefer, cooling; } \\
\text { GLO }\end{array}$ \\
\hline
\end{tabular}


63 The list of the processes related to other products and technologies are listed in Table C2. All the processes are based on Ecoinvent 3.3 Consequential (Wernet et

64 al., 2017).

65 Table C2: List of the processes related to other products and technologies. All the processes are based on Ecoinvent 3.3 Consequential (Wernet et al., 2017).

\begin{tabular}{|c|c|c|}
\hline Process & Process(es) in Ecoinvent for the production & Process(es) in Ecoinvent for the transport \\
\hline PET & $\begin{array}{l}\text { Polyethylene terephthalate production, } \\
\text { granulate, bottle grade; RoW }\end{array}$ & $\begin{array}{l}\text { - } \quad \text { Transport, freight train; FR } \\
\text { - Transport, freight, lorry, all sizes, EURO4 to generic market } \\
\quad \text { for transport, freight, lorry, unspecified; RoW } \\
\text { - Transport, freight, sea, transoceanic ship; GLO }\end{array}$ \\
\hline
\end{tabular}




\begin{tabular}{|c|c|c|}
\hline PP & $\begin{array}{l}\text { - Polypropylene production, } \\
\text { granulate; RoW }\end{array}$ & $\begin{array}{ll}- & \text { Transport, freight train; } F R \\
\text { - } & \text { Transport, freight, lorry, all sizes, EURO4 to generic market } \\
& \text { for transport, freight, lorry, unspecified; RoW } \\
\text { - } \quad \text { Transport, freight, sea, transoceanic ship; } G L O\end{array}$ \\
\hline PE & $\begin{array}{l}\text { - Polyethylene production, high density, } \\
\text { granulate; RoW }\end{array}$ & $\begin{array}{l}\text { - } \quad \text { Transport, freight train; FR } \\
\text { - } \quad \text { Transport, freight, lorry, all sizes, EURO4 to generic market } \\
\text { for transport, freight, lorry, unspecified; RoW } \\
\text { - } \quad \text { Transport, freight, sea, transoceanic ship; GLO }\end{array}$ \\
\hline $\begin{array}{l}\text { Marginal } \\
\text { electricity }\end{array}$ & $\begin{array}{l}\text { - } \quad \text { Market for electricity, high voltage; } \\
F R\end{array}$ & \\
\hline Marginal N-fertilizer & $\begin{array}{l}\text { - Urea ammonium nitrate production; } \\
\text { RoW }\end{array}$ & \\
\hline Marginal K-fertilizer & $\begin{array}{l}\text { - Potassium chloride production; } \\
\text { RoW }\end{array}$ & \\
\hline Marginal P-fertilizer & 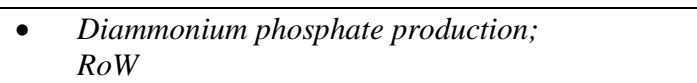 & \\
\hline Marginal energy-feed & $\begin{array}{l}\text { Maize grain, feed production; } \\
\text { RoW }\end{array}$ & $\begin{array}{l}\text { - } \quad \text { Transport, freight train; FR } \\
\text { - } \quad \text { Transport, freight, inland waterways, barge with reefer, } \\
\text { cooling; GLO } \\
\text { - } \quad \text { Transport, freight, lorry, all sizes, EURO4 to generic market } \\
\quad \text { for transport, freight, lorry, unspecified; RoW } \\
\text { - Transport, freight, sea, transoceanic ship; GLO }\end{array}$ \\
\hline Marginal protein-feed & - $\quad$ Soybean production; $R o W$ & $\begin{array}{ll}- & \text { Transport, freight train; FR } \\
\text { - } & \text { Transport, freight, light commercial vehicle; RoW } \\
\text { - } & \text { Transport, freight, lorry, all sizes, EURO4 to generic market } \\
& \text { for transport, freight, lorry, unspecified; RoW } \\
\text { - } \quad \text { Transport, freight, sea, transoceanic ship; } \text { GLO }\end{array}$ \\
\hline Palm oil & & $\begin{array}{ll}\text { - } & \text { Transport, freight train; } F R \\
\text { - } & \text { Transport, freight, light commercial vehicle; RoW } \\
\text { - } & \text { Transport, freight, lorry, all sizes, EURO4 to generic market } \\
& \text { for transport, freight, lorry, unspecified; RoW } \\
\text { - } \quad \text { Transport, freight, sea, transoceanic ship; } \text { GLO }\end{array}$ \\
\hline $\begin{array}{l}\text { Refrigeration, } \\
\text { electricity }\end{array}$ & $\begin{array}{l}\text { - Market for electricity, low voltage; } \\
F R\end{array}$ & \\
\hline $\begin{array}{l}\text { Marginal electricity, } \\
\text { sensitivity analysis }\end{array}$ & $\begin{array}{l}\text { - } \begin{array}{l}\text { Electricity production, natural gas, conventional } \\
\text { power plant; } F R\end{array} \\
\end{array}$ & \\
\hline
\end{tabular}

67 The LCIs of some processes were based on the ones present in EASETECH (Clavreul et al., 2014). These processes are listed in Table C3. 


\begin{tabular}{|l|ll|}
\hline Process & & \multicolumn{1}{c|}{ Process in EASETECH } \\
\hline Collection truck & $\bullet$ & Collection Vehicle, 10t Euro3, urban traffic, 1 litre diesel, 2006 \\
\hline Recycling of Paper & $\bullet$ & $\begin{array}{l}\text { Paper (Cardboard and mixed paper) to cardboard, } \\
\text { Fiskybybruk, Sweden, 2006 [with substitution] }\end{array}$ \\
\hline Palm fruit & $\bullet$ & Palm fruit, conventional. Global 2000-2010 \\
\hline Transport & $\bullet \quad$ Truck, <7.5, Euro6, urban traffic \\
\hline Refrigeration, heat & $\bullet \begin{array}{l}\text { Heat production, natural gas, at boiler fan burner low-NOx } \\
\text { non-modulation <100kW; Europe without Switzerland }\end{array}$ \\
\hline Marginal heat & $\bullet \begin{array}{l}\text { Heat production, natural gas, at boiler fan burner low-NOx } \\
\text { non-modulation <100kW; Europe without Switzerland }\end{array}$ \\
\hline Paper production & $\bullet \begin{array}{l}\text { Cardboard, 1 kg, Skoghall Mill, Sweden, weighted average } \\
2005+2007\end{array}$ \\
\hline
\end{tabular}


72 Table D1 provides the land demanded for all the food products considered in the study.

73 Table D1: Land demanded for the food products considered in the study.

\begin{tabular}{|c|c|c|c|c|}
\hline Name of process & Amount & Unit & Per & Source \\
\hline Swine production, live weight; GLO & 5.94 & $\mathrm{~m} 2 * \mathrm{y}$ & kg Total Wet Weight & Ecoinvent 3.3 \\
\hline $\begin{array}{l}\text { Cattle production for slaughtering, live weight to } \\
\text { generic market for red meat, live weight; GLO }\end{array}$ & 9.98 & $\mathrm{~m} 2 * \mathrm{y}$ & kg Total Wet Weight & Ecoinvent 3.3 \\
\hline Chicken production; GLO & 2.36 & $\mathrm{~m} 2 * \mathrm{y}$ & kg Total Wet Weight & Ecoinvent 3.3 \\
\hline Sheep production; GLO & 23.86 & $\mathrm{~m} 2 * \mathrm{y}$ & kg Total Wet Weight & Ecoinvent 3.3 \\
\hline Cow milk production; GLO & 1.31 & $\mathrm{~m} 2 * \mathrm{y}$ & kg Total Wet Weight & Ecoinvent 3.3 \\
\hline $\begin{array}{l}\text { Cheese production, from cow milk, fresh, } \\
\text { unripened; GLO }\end{array}$ & 9.01 & $\mathrm{~m} 2 * \mathrm{y}$ & kg Total Wet Weight & Ecoinvent 3.3 \\
\hline Production of butter; GLO & -24.81 & $\mathrm{~m} 2 * \mathrm{y}$ & kg Total Wet Weight & Ecoinvent 3.3 \\
\hline Yogurt production, from cow milk; GLO & 1.35 & $\mathrm{~m} 2 * \mathrm{y}$ & kg Total Wet Weight & Ecoinvent 3.3 \\
\hline Fish products & 0.00 & $\mathrm{~m} 2 * \mathrm{y}$ & kg Total Wet Weight & Ecoinvent 3.3 \\
\hline Wheat bread, conventional, fresh; GLO (adapted) & 2.17 & $\mathrm{~m} 2 * \mathrm{y}$ & kg Total Wet Weight & $\begin{array}{l}\text { Ecoinvent } 3.3+ \\
\text { LCA food DK }\end{array}$ \\
\hline Rice production; GLO & 0.01 & $\mathrm{~m} 2 * \mathrm{y}$ & kg Total Wet Weight & Ecoinvent 3.3 \\
\hline Flour production; GLO & 3.10 & $\mathrm{~m} 2 * \mathrm{y}$ & kg Total Wet Weight & Ecoinvent 3.3 \\
\hline Orange production; GLO & 0.22 & $\mathrm{~m} 2 * \mathrm{y}$ & kg Total Wet Weight & Ecoinvent 3.3 \\
\hline Lemon production; GLO & 0.37 & $\mathrm{~m} 2 * \mathrm{y}$ & kg Total Wet Weight & Ecoinvent 3.3 \\
\hline Apple production; GLO & 0.36 & $\mathrm{~m} 2 * \mathrm{y}$ & kg Total Wet Weight & Ecoinvent 3.3 \\
\hline Pear production; GLO & 0.49 & $\mathrm{~m} 2 * \mathrm{y}$ & kg Total Wet Weight & Ecoinvent 3.3 \\
\hline Grape production; GLO & 0.36 & $\mathrm{~m} 2 * \mathrm{y}$ & kg Total Wet Weight & Ecoinvent 3.3 \\
\hline Banana production; GLO & 0.20 & $\mathrm{~m} 2 * \mathrm{y}$ & kg Total Wet Weight & Ecoinvent 3.3 \\
\hline Melon production; RoW & 0.09 & $\mathrm{~m} 2 * \mathrm{y}$ & kg Total Wet Weight & Ecoinvent 3.3 \\
\hline Cauliflower production; GLO & 0.17 & $\mathrm{~m} 2 * \mathrm{y}$ & kg Total Wet Weight & Ecoinvent 3.3 \\
\hline Lettuce production; GLO & 3.44 & $\mathrm{~m} 2 * \mathrm{y}$ & kg Total Wet Weight & Ecoinvent 3.3 \\
\hline Pea protein production; GLO & 3.09 & $\mathrm{~m} 2 * \mathrm{y}$ & kg Total Wet Weight & Ecoinvent 3.3 \\
\hline Carrot production; GLO & 0.21 & $\mathrm{~m} 2 * \mathrm{y}$ & kg Total Wet Weight & Ecoinvent 3.3 \\
\hline Onion production; GLO & 0.21 & $\mathrm{~m} 2 * \mathrm{y}$ & kg Total Wet Weight & Ecoinvent 3.3 \\
\hline Tomato production; GLO & 0.23 & $\mathrm{~m} 2 * \mathrm{y}$ & kg Total Wet Weight & Ecoinvent 3.3 \\
\hline Potato production; GLO & 0.41 & $\mathrm{~m} 2 * \mathrm{y}$ & kg Total Wet Weight & Ecoinvent 3.3 \\
\hline Apricot production; GLO & 0.36 & $\mathrm{~m} 2 * \mathrm{y}$ & kg Total Wet Weight & Ecoinvent 3.3 \\
\hline Aubergine production; GLO & 4.22 & $\mathrm{~m} 2 * \mathrm{y}$ & kg Total Wet Weight & Ecoinvent 3.3 \\
\hline Avocado production; GLO & 1.11 & $\mathrm{~m} 2 * \mathrm{y}$ & kg Total Wet Weight & Ecoinvent 3.3 \\
\hline Broccoli production; GLO & 0.17 & $\mathrm{~m} 2 * \mathrm{y}$ & kg Total Wet Weight & Ecoinvent 3.3 \\
\hline Cream production; GLO & -0.10 & $\mathrm{~m} 2 * \mathrm{y}$ & kg Total Wet Weight & Ecoinvent 3.3 \\
\hline Celery production; GLO & 0.16 & $\mathrm{~m} 2 * \mathrm{y}$ & kg Total Wet Weight & Ecoinvent 3.3 \\
\hline Cucumber production; GLO & 3.27 & $\mathrm{~m} 2 * \mathrm{y}$ & kg Total Wet Weight & Ecoinvent 3.3 \\
\hline Fennel production; GLO & 0.23 & $\mathrm{~m} 2 * \mathrm{y}$ & kg Total Wet Weight & Ecoinvent 3.3 \\
\hline Green asparagus production; GLO & 3.46 & $\mathrm{~m} 2 * \mathrm{y}$ & kg Total Wet Weight & Ecoinvent 3.3 \\
\hline Green bell pepper; GLO & 2.06 & $\mathrm{~m} 2 * \mathrm{y}$ & kg Total Wet Weight & Ecoinvent 3.3 \\
\hline Kiwi production; GLO & 0.32 & $\mathrm{~m} 2 * \mathrm{y}$ & kg Total Wet Weight & Ecoinvent 3.3 \\
\hline Mandarin production, RoW & 0.70 & $\mathrm{~m} 2 * \mathrm{y}$ & kg Total Wet Weight & Ecoinvent 3.3 \\
\hline Peach production; RoW & 0.42 & $\mathrm{~m} 2 * \mathrm{y}$ & kg Total Wet Weight & Ecoinvent 3.3 \\
\hline Pineapple production; GLO & 0.25 & $\mathrm{~m} 2 * \mathrm{y}$ & kg Total Wet Weight & Ecoinvent 3.3 \\
\hline Spinach production, GLO & 0.06 & $\mathrm{~m} 2 * \mathrm{y}$ & kg Total Wet Weight & Ecoinvent 3.3 \\
\hline Strawberry production; GLO & 0.26 & $\mathrm{~m} 2 * \mathrm{y}$ & kg Total Wet Weight & Ecoinvent 3.3 \\
\hline Zucchini production, GLO & 0.15 & $\mathrm{~m} 2 * \mathrm{y}$ & kg Total Wet Weight & Ecoinvent 3.3 \\
\hline Orange juice production & 0.50 & $\mathrm{~m} 2 * \mathrm{y}$ & kg Total Wet Weight & Ecoinvent 3.3 \\
\hline Radish production, GLO & 7.93 & $\mathrm{~m} 2 * \mathrm{y}$ & kg Total Wet Weight & Ecoinvent 3.3 \\
\hline Watermelon production & 0.01 & $\mathrm{~m} 2 * \mathrm{y}$ & kg Total Wet Weight & Ecoinvent 3.3 \\
\hline Artichoke production & 0.03 & $\mathrm{~m} 2 * \mathrm{y}$ & kg Total Wet Weight & Ecoinvent 3.3 \\
\hline Chestnut production & 0.43 & $\mathrm{~m} 2 * \mathrm{y}$ & kg Total Wet Weight & Ecoinvent 3.3 \\
\hline Pasta production & 6.48 & $\mathrm{~m} 2 * \mathrm{y}$ & kg Total Wet Weight & Ecoinvent 3.3 \\
\hline
\end{tabular}




\begin{tabular}{|l|c|l|l|l|l|} 
Pastry production & -3.53 & $\mathrm{~m} 2 * \mathrm{y}$ & $\mathrm{kg}$ Total Wet Weight & Ecoinvent 3.3 \\
\hline Croissant production & 1.17 & $\mathrm{~m} 2 * \mathrm{y}$ & $\mathrm{kg}$ Total Wet Weight & Ecoinvent 3.3 \\
\hline Biscuit production & -3.84 & $\mathrm{~m} 2 * \mathrm{y}$ & $\mathrm{kg}$ Total Wet Weight & Ecoinvent 3.3 \\
\hline Pizza production & 6.63 & $\mathrm{~m} 2 * \mathrm{y}$ & $\mathrm{kg}$ Total Wet Weight & Ecoinvent 3.3 \\
\hline
\end{tabular}

74

75 


\section{Appendix E}

77 The default results together with the scenario analysis where the marginal electricity is changed are displayed in Figure

78 E1. The default results together with the scenario analysis where the management of the packaging is varied are

79 displayed in Figure E2. The default results together with the scenario analysis where the losses incurred by

80 beneficiaries are accounted for are displayed in Figure E3. Note that "GW" =Global Warming; "TA"=Terrestrial

81 Acidification; "POF"=Photochemical Ozone Formation; "PM"=Particulate Matter; "AE, N"=Aquatic Eutrophication,

82 Nitrogen; "AE, P"=Aquatic Eutrophication, Phosphorus; "ET"= Ecotoxicity; "HT, cancer"=Human Toxicity, cancer;

83 "FRD"=Fossil Resource Depletion; "WD”=Water Depletion.

84 

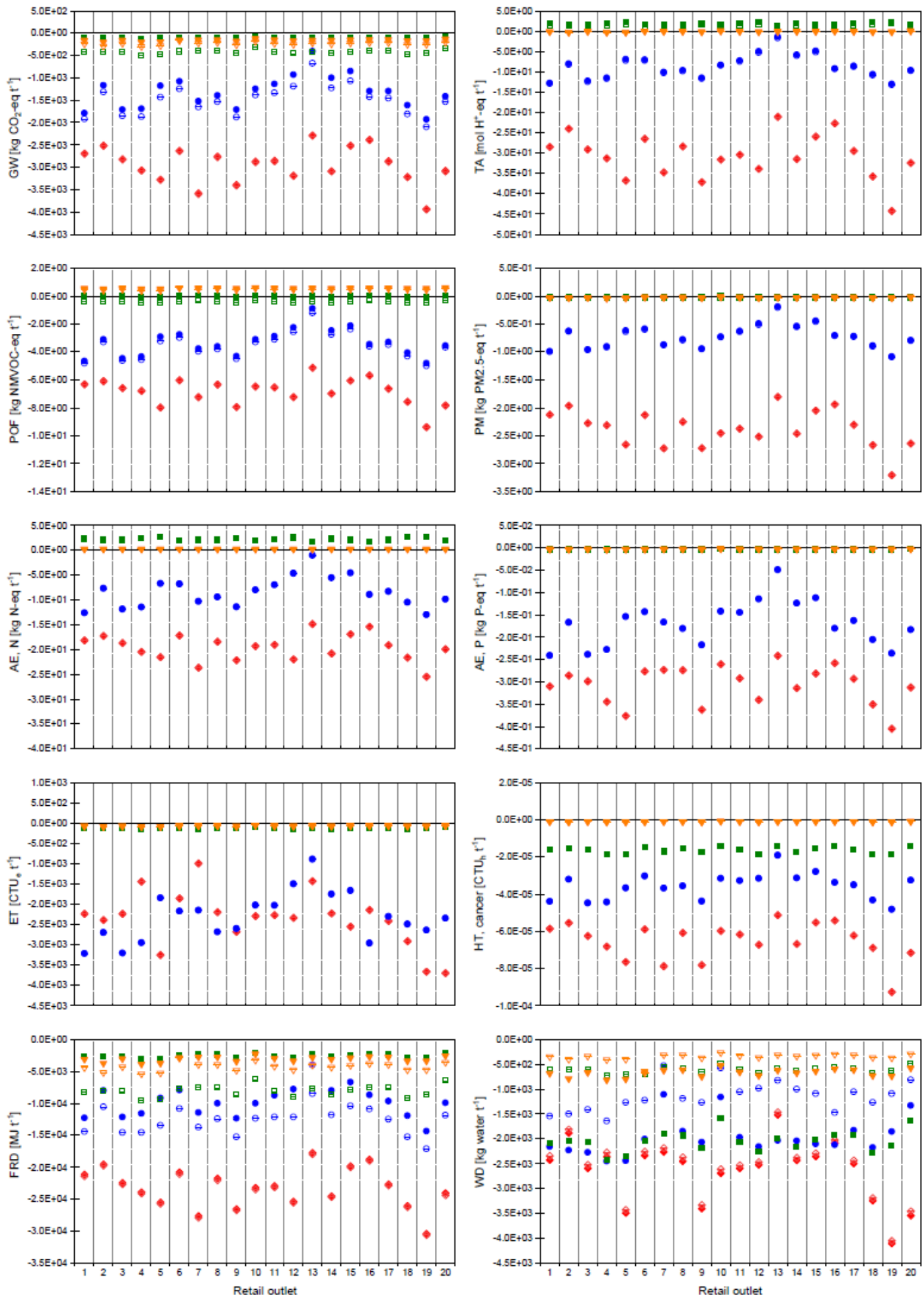

- Current management - default $\ominus$ Current management - SA
- Anaerobic digestion - default $\quad \nabla$ Incineration - default $\boxminus$ Anaerobic digestion - SA
- Prevention - default $\ominus$ Prevention - SA

Figure E1: The default results are displayed together with the scenario analysis performed on the marginal electricity. 

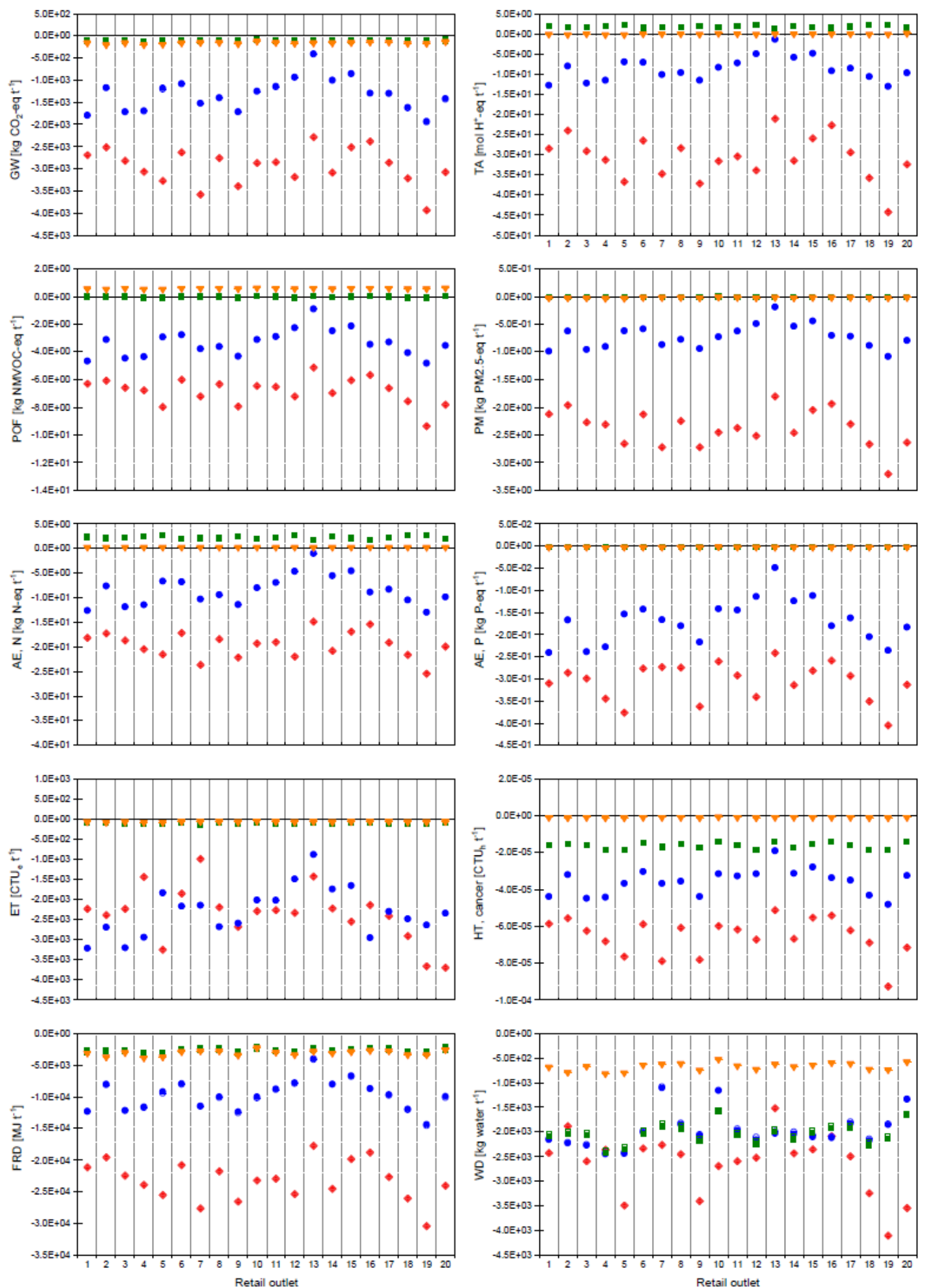

- Current management - default

- Anaerobic digestion - default

$\nabla$ Incineration - default

$\ominus$ Current management - SA

$\boxminus$ Anaerobic digestion - SA

$\nabla$ Incineration - SA

Prevention - default $\diamond$ Prevention - SA

Figure E2: The default results are displayed together with the scenario analysis on the management of the packaging. 

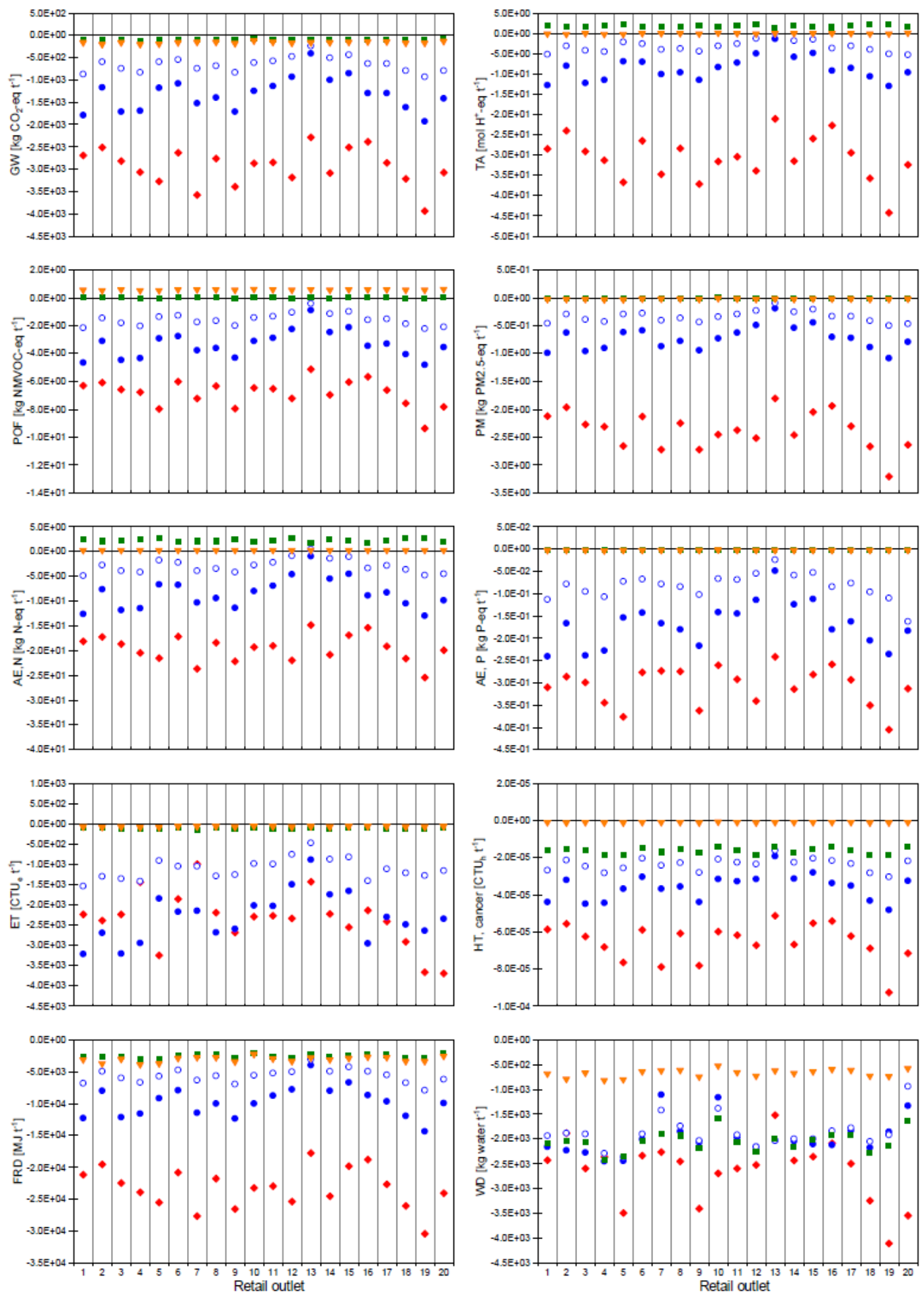

- Scenario I (CM)- default Scenario II (AD) V Scenario III (I) • Scenario IV (P)

Figure E 3: The default results are displayed together with the scenario analysis performed on the losses incurred by the beneficiaries of the redistribution of surplus food. 
93 Table F1 summarises the results of the environmental assessment. The total, together with the main contributors to the savings/impacts are reported for all the

94 retails, all the scenarios, and all the impact categories considered in the study. Note that: $\mathrm{LUC}=$ indirect land use changes; $\mathrm{FP}=$ food production; $\mathrm{PP}=$ packaging

95 production; $\mathrm{AFP}=$ animal feed production; TRCS=transport, refrigeration, cooling and storage; WM\&C=waste management and collection. Note that all numbers

96 are rounded.

99 Table F1: Note that "LUC"=indirect land use changes; "FP"=food production; "PP"=packaging production; "AFP"=animal feed production; "TRCS"= transport, refrigeration,

100 cooling and storage; "WM\&C"=waste management and collection. Please note that the numbers were rounded to two significant digits.

\begin{tabular}{|c|c|c|c|c|c|c|c|c|c|c|c|c|c|c|c|c|c|c|c|c|c|}
\hline \multicolumn{2}{|c|}{ Global Warming } & \#1 & \#2 & \#3 & \#4 & \#5 & \#6 & $\# 7$ & $\# 8$ & \#9 & \#10 & $\# 11$ & $\# 12$ & $\# 13$ & $\# 14$ & $\# 15$ & $\# 16$ & \#17 & $\# 18$ & $\# 19$ & $\# 20$ \\
\hline \multirow{7}{*}{ 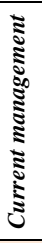 } & LUC & $31 \%$ & $34 \%$ & $27 \%$ & $32 \%$ & $29 \%$ & $30 \%$ & $25 \%$ & $29 \%$ & $28 \%$ & $23 \%$ & $28 \%$ & $27 \%$ & $28 \%$ & $28 \%$ & $30 \%$ & $33 \%$ & $28 \%$ & $28 \%$ & $26 \%$ & $34 \%$ \\
\hline & FP & $64 \%$ & $58 \%$ & $67 \%$ & $62 \%$ & $62 \%$ & $61 \%$ & $69 \%$ & $64 \%$ & $66 \%$ & $70 \%$ & $64 \%$ & $63 \%$ & $48 \%$ & $63 \%$ & $59 \%$ & $60 \%$ & $65 \%$ & $66 \%$ & $69 \%$ & $57 \%$ \\
\hline & $\begin{array}{l}\mathrm{PP} \\
\end{array}$ & $1 \%$ & $1 \%$ & $1 \%$ & $1 \%$ & $1 \%$ & $1 \%$ & $2 \%$ & $1 \%$ & $1 \%$ & $1 \%$ & $1 \%$ & $1 \%$ & $1 \%$ & $1 \%$ & $1 \%$ & $1 \%$ & $1 \%$ & $1 \%$ & $1 \%$ & $1 \%$ \\
\hline & AFP & $0 \%$ & $0 \%$ & $0 \%$ & $0 \%$ & $0 \%$ & $0 \%$ & $0 \%$ & $0 \%$ & $0 \%$ & $0 \%$ & $0 \%$ & $0 \%$ & $0 \%$ & $0 \%$ & $0 \%$ & $0 \%$ & $0 \%$ & $0 \%$ & $0 \%$ & $5 \%$ \\
\hline & TRCS & $2 \%$ & $3 \%$ & $2 \%$ & $2 \%$ & $2 \%$ & $3 \%$ & $2 \%$ & $3 \%$ & $2 \%$ & $3 \%$ & $2 \%$ & $2 \%$ & $3 \%$ & $2 \%$ & $3 \%$ & $3 \%$ & $3 \%$ & $2 \%$ & $2 \%$ & $2 \%$ \\
\hline & WM\&C & $2 \%$ & $4 \%$ & $2 \%$ & $3 \%$ & $6 \%$ & $5 \%$ & $3 \%$ & $3 \%$ & $3 \%$ & $3 \%$ & $5 \%$ & $7 \%$ & $20 \%$ & $6 \%$ & $7 \%$ & $3 \%$ & $3 \%$ & $3 \%$ & $2 \%$ & $2 \%$ \\
\hline & $\begin{array}{l}\text { Total } \\
{\left[\mathrm{kgCO}_{2-\mathrm{eq}} \mathrm{t}^{-1}\right]}\end{array}$ & $\begin{array}{l}-1800 \\
\end{array}$ & -1200 & $\begin{array}{l}-1700 \\
\end{array}$ & -1700 & -1200 & -1100 & -1500 & $\begin{array}{l}-1400 \\
\end{array}$ & -1700 & -1200 & -1100 & -920 & -400 & -990 & $\begin{array}{l}-840 \\
\end{array}$ & -1300 & $\begin{array}{l}-1300 \\
\end{array}$ & -1600 & -1900 & -1400 \\
\hline \multirow{7}{*}{ 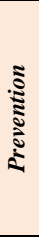 } & LUC & $19 \%$ & $22 \%$ & $19 \%$ & $18 \%$ & $20 \%$ & $18 \%$ & $12 \%$ & $17 \%$ & $17 \%$ & $13 \%$ & $17 \%$ & $18 \%$ & $18 \%$ & $17 \%$ & $21 \%$ & $20 \%$ & $18 \%$ & $19 \%$ & $17 \%$ & $20 \%$ \\
\hline & FP & $76 \%$ & $74 \%$ & $77 \%$ & $78 \%$ & $76 \%$ & $78 \%$ & $85 \%$ & $78 \%$ & $79 \%$ & $83 \%$ & $79 \%$ & $78 \%$ & $78 \%$ & $79 \%$ & $75 \%$ & $76 \%$ & $78 \%$ & $77 \%$ & $80 \%$ & $77 \%$ \\
\hline & PP & $2 \%$ & $1 \%$ & $2 \%$ & $2 \%$ & $2 \%$ & $1 \%$ & $1 \%$ & $1 \%$ & $2 \%$ & $2 \%$ & $2 \%$ & $2 \%$ & $1 \%$ & $2 \%$ & $2 \%$ & $2 \%$ & $2 \%$ & $2 \%$ & $2 \%$ & $1 \%$ \\
\hline & AFP & $0 \%$ & $0 \%$ & $0 \%$ & $0 \%$ & $0 \%$ & $0 \%$ & $0 \%$ & $0 \%$ & $0 \%$ & $0 \%$ & $0 \%$ & $0 \%$ & $0 \%$ & $0 \%$ & $0 \%$ & $0 \%$ & $0 \%$ & $0 \%$ & $0 \%$ & $0 \%$ \\
\hline & TRCS & $3 \%$ & $3 \%$ & $3 \%$ & $2 \%$ & $2 \%$ & $3 \%$ & $2 \%$ & $3 \%$ & $2 \%$ & $3 \%$ & $3 \%$ & $2 \%$ & $3 \%$ & $2 \%$ & $3 \%$ & $3 \%$ & $3 \%$ & $2 \%$ & $2 \%$ & $2 \%$ \\
\hline & WM\&C & $0 \%$ & $0 \%$ & $0 \%$ & $0 \%$ & $0 \%$ & $0 \%$ & $0 \%$ & $0 \%$ & $0 \%$ & $0 \%$ & $0 \%$ & $0 \%$ & $0 \%$ & $0 \%$ & $0 \%$ & $0 \%$ & $0 \%$ & $0 \%$ & $0 \%$ & $0 \%$ \\
\hline & $\begin{array}{l}\text { Total } \\
{\left[\mathrm{kgCO}_{2-\mathrm{eq}} \mathbf{t}^{-1}\right]}\end{array}$ & -2700 & -2500 & -2800 & -3100 & -3300 & -2600 & -3600 & -2800 & -3400 & -2900 & -2800 & -3200 & -2300 & -3100 & -2500 & -2400 & -2900 & -3200 & -3900 & -3100 \\
\hline \multirow{7}{*}{ 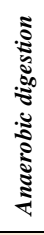 } & LUC & $0 \%$ & $0 \%$ & $0 \%$ & $0 \%$ & $0 \%$ & $0 \%$ & $0 \%$ & $0 \%$ & $0 \%$ & $0 \%$ & $0 \%$ & $0 \%$ & $0 \%$ & $0 \%$ & $0 \%$ & $0 \%$ & $0 \%$ & $0 \%$ & $0 \%$ & $0 \%$ \\
\hline & FP & $0 \%$ & $0 \%$ & $0 \%$ & $0 \%$ & $0 \%$ & $0 \%$ & $0 \%$ & $0 \%$ & $0 \%$ & $0 \%$ & $0 \%$ & $0 \%$ & $0 \%$ & $0 \%$ & $0 \%$ & $0 \%$ & $0 \%$ & $0 \%$ & $0 \%$ & $0 \%$ \\
\hline & PP & $0 \%$ & $0 \%$ & $0 \%$ & $0 \%$ & $0 \%$ & $0 \%$ & $0 \%$ & $0 \%$ & $0 \%$ & $0 \%$ & $0 \%$ & $0 \%$ & $0 \%$ & $0 \%$ & $0 \%$ & $0 \%$ & $0 \%$ & $0 \%$ & $0 \%$ & $0 \%$ \\
\hline & AFP & $0 \%$ & $0 \%$ & $0 \%$ & $0 \%$ & $0 \%$ & $0 \%$ & $0 \%$ & $0 \%$ & $0 \%$ & $0 \%$ & $0 \%$ & $0 \%$ & $0 \%$ & $0 \%$ & $0 \%$ & $0 \%$ & $0 \%$ & $0 \%$ & $0 \%$ & $0 \%$ \\
\hline & TRCS & $-1 \%$ & $0 \%$ & $-1 \%$ & $-1 \%$ & $-1 \%$ & $-1 \%$ & $-1 \%$ & $-1 \%$ & $-1 \%$ & $-1 \%$ & $-1 \%$ & $-1 \%$ & $-1 \%$ & $-1 \%$ & $-1 \%$ & $-1 \%$ & $-1 \%$ & $-1 \%$ & $-1 \%$ & $-1 \%$ \\
\hline & WM\&C & $101 \%$ & $100 \%$ & $101 \%$ & $101 \%$ & $101 \%$ & $101 \%$ & $101 \%$ & $101 \%$ & $101 \%$ & $101 \%$ & $101 \%$ & $101 \%$ & $101 \%$ & $101 \%$ & $101 \%$ & $101 \%$ & $101 \%$ & $101 \%$ & $101 \%$ & $101 \%$ \\
\hline & $\begin{array}{l}\text { Total } \\
{\left[\mathrm{kgCO}_{2-\mathrm{eq}} \mathbf{t}^{-1}\right]}\end{array}$ & -90 & -130 & -92 & -110 & -100 & -94 & -90 & -90 & -95 & -65 & -90 & -95 & -95 & -94 & -89 & -88 & -84 & -95 & -88 & -69 \\
\hline \multirow{6}{*}{ 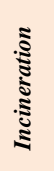 } & LUC & $0 \%$ & $0 \%$ & $0 \%$ & $0 \%$ & $0 \%$ & $0 \%$ & $0 \%$ & $0 \%$ & $0 \%$ & $0 \%$ & $0 \%$ & $0 \%$ & $0 \%$ & $0 \%$ & $0 \%$ & $0 \%$ & $0 \%$ & $0 \%$ & $0 \%$ & $0 \%$ \\
\hline & FP & $0 \%$ & $0 \%$ & $0 \%$ & $0 \%$ & $0 \%$ & $0 \%$ & $0 \%$ & $0 \%$ & $0 \%$ & $0 \%$ & $0 \%$ & $0 \%$ & $0 \%$ & $0 \%$ & $0 \%$ & $0 \%$ & $0 \%$ & $0 \%$ & $0 \%$ & $0 \%$ \\
\hline & $\begin{array}{l}\mathrm{PP} \\
\end{array}$ & $0 \%$ & $0 \%$ & $0 \%$ & $0 \%$ & $0 \%$ & $0 \%$ & $0 \%$ & $0 \%$ & $0 \%$ & $0 \%$ & $0 \%$ & $0 \%$ & $0 \%$ & $0 \%$ & $0 \%$ & $0 \%$ & $0 \%$ & $0 \%$ & $0 \%$ & $0 \%$ \\
\hline & AFP & $0 \%$ & $0 \%$ & $0 \%$ & $0 \%$ & $0 \%$ & $0 \%$ & $0 \%$ & $0 \%$ & $0 \%$ & $0 \%$ & $0 \%$ & $0 \%$ & $0 \%$ & $0 \%$ & $0 \%$ & $0 \%$ & $0 \%$ & $0 \%$ & $0 \%$ & $0 \%$ \\
\hline & TRCS & $-2 \%$ & $-1 \%$ & $-2 \%$ & $-1 \%$ & $-2 \%$ & $-2 \%$ & $-2 \%$ & $-2 \%$ & $-2 \%$ & $-3 \%$ & $-2 \%$ & $-2 \%$ & $-2 \%$ & $-2 \%$ & $-2 \%$ & $-2 \%$ & $-2 \%$ & $-2 \%$ & $-2 \%$ & $-2 \%$ \\
\hline & WM\&C & $102 \%$ & $101 \%$ & $102 \%$ & $101 \%$ & $102 \%$ & $102 \%$ & $102 \%$ & $102 \%$ & $102 \%$ & $103 \%$ & $102 \%$ & $102 \%$ & $102 \%$ & $102 \%$ & $102 \%$ & $102 \%$ & $102 \%$ & $102 \%$ & $102 \%$ & $102 \%$ \\
\hline
\end{tabular}




\begin{tabular}{|c|c|c|c|c|c|c|c|c|c|c|c|c|c|c|c|c|c|c|c|c|c|}
\hline & $\begin{array}{l}\text { Total } \\
{\left[\mathrm{kgCO}_{2-\mathrm{eq}} \mathrm{t}^{-1}\right]}\end{array}$ & -160 & -200 & -150 & -200 & -180 & -150 & -150 & -140 & -170 & -110 & -150 & -160 & -150 & -150 & -140 & -140 & -140 & -160 & -160 & -130 \\
\hline \multicolumn{22}{|c|}{ Terrestrial acidification } \\
\hline \multirow{7}{*}{ 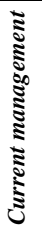 } & LUC & $21 \%$ & $24 \%$ & $19 \%$ & $23 \%$ & $24 \%$ & $23 \%$ & $18 \%$ & $21 \%$ & $20 \%$ & $17 \%$ & $22 \%$ & $25 \%$ & $42 \%$ & $23 \%$ & $26 \%$ & $23 \%$ & $21 \%$ & $21 \%$ & $19 \%$ & $24 \%$ \\
\hline & FP & $81 \%$ & $81 \%$ & $85 \%$ & $82 \%$ & $95 \%$ & $86 \%$ & $86 \%$ & $83 \%$ & $85 \%$ & $90 \%$ & $90 \%$ & $104 \%$ & $140 \%$ & $95 \%$ & $95 \%$ & $79 \%$ & $87 \%$ & $87 \%$ & $87 \%$ & $72 \%$ \\
\hline & PP & $1 \%$ & $0 \%$ & $1 \%$ & $1 \%$ & $1 \%$ & $1 \%$ & $1 \%$ & $1 \%$ & $1 \%$ & $1 \%$ & $1 \%$ & $1 \%$ & $1 \%$ & $1 \%$ & $1 \%$ & $1 \%$ & $1 \%$ & $1 \%$ & $1 \%$ & $1 \%$ \\
\hline & AFP & $0 \%$ & $0 \%$ & $0 \%$ & $0 \%$ & $0 \%$ & $0 \%$ & $0 \%$ & $0 \%$ & $0 \%$ & $0 \%$ & $0 \%$ & $0 \%$ & $0 \%$ & $0 \%$ & $0 \%$ & $0 \%$ & $0 \%$ & $0 \%$ & $0 \%$ & $8 \%$ \\
\hline & TRCS & $3 \%$ & $4 \%$ & $2 \%$ & $2 \%$ & $2 \%$ & $3 \%$ & $2 \%$ & $3 \%$ & $2 \%$ & $3 \%$ & $3 \%$ & $3 \%$ & $7 \%$ & $3 \%$ & $4 \%$ & $4 \%$ & $3 \%$ & $2 \%$ & $2 \%$ & $2 \%$ \\
\hline & WM\&C & $-5 \%$ & $-9 \%$ & $-6 \%$ & $-8 \%$ & $-22 \%$ & $-12 \%$ & $-7 \%$ & $-8 \%$ & $-9 \%$ & $-11 \%$ & $-15 \%$ & $-32 \%$ & $-89 \%$ & $-22 \%$ & $-25 \%$ & $-7 \%$ & $-11 \%$ & $-11 \%$ & $-8 \%$ & $-7 \%$ \\
\hline & $\begin{array}{ll}\text { Total } & \\
{\left[\text { molH }^{+} \text {-eq }\right.} & \left.\mathbf{t}^{-1}\right]\end{array}$ & -13 & -7.9 & -12 & -11 & -6.9 & -7.0 & -10 & -10 & -11 & -10 & -10 & -10 & -10 & -10 & -10 & -10 & -10 & -11 & -13 & -10 \\
\hline \multirow{7}{*}{ 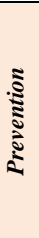 } & LUC & $9 \%$ & $11 \%$ & $9 \%$ & $9 \%$ & $9 \%$ & $9 \%$ & $6 \%$ & $8 \%$ & $8 \%$ & $6 \%$ & $8 \%$ & $8 \%$ & $9 \%$ & $8 \%$ & $10 \%$ & $10 \%$ & $8 \%$ & $8 \%$ & $7 \%$ & $9 \%$ \\
\hline & FP & $89 \%$ & $86 \%$ & $89 \%$ & $89 \%$ & $89 \%$ & $89 \%$ & $92 \%$ & $89 \%$ & $90 \%$ & $92 \%$ & $90 \%$ & $90 \%$ & $87 \%$ & $89 \%$ & $87 \%$ & $87 \%$ & $89 \%$ & $90 \%$ & $91 \%$ & $89 \%$ \\
\hline & PP & $1 \%$ & $1 \%$ & $1 \%$ & $1 \%$ & $1 \%$ & $1 \%$ & $1 \%$ & $1 \%$ & $1 \%$ & $1 \%$ & $1 \%$ & $1 \%$ & $1 \%$ & $1 \%$ & $1 \%$ & $1 \%$ & $1 \%$ & $1 \%$ & $1 \%$ & $0 \%$ \\
\hline & AFP & $0 \%$ & $0 \%$ & $0 \%$ & $0 \%$ & $0 \%$ & $0 \%$ & $0 \%$ & $0 \%$ & $0 \%$ & $0 \%$ & $0 \%$ & $0 \%$ & $0 \%$ & $0 \%$ & $0 \%$ & $0 \%$ & $0 \%$ & $0 \%$ & $0 \%$ & $0 \%$ \\
\hline & TRCS & $2 \%$ & $2 \%$ & $2 \%$ & $2 \%$ & $1 \%$ & $2 \%$ & $2 \%$ & $2 \%$ & $1 \%$ & $2 \%$ & $2 \%$ & $2 \%$ & $3 \%$ & $2 \%$ & $2 \%$ & $2 \%$ & $2 \%$ & $1 \%$ & $1 \%$ & $2 \%$ \\
\hline & WM\&C & $0 \%$ & $0 \%$ & $0 \%$ & $0 \%$ & $0 \%$ & $0 \%$ & $0 \%$ & $0 \%$ & $0 \%$ & $0 \%$ & $0 \%$ & $0 \%$ & $0 \%$ & $0 \%$ & $0 \%$ & $0 \%$ & $0 \%$ & $0 \%$ & $0 \%$ & $0 \%$ \\
\hline & $\begin{array}{l}\text { Total } \\
{\left[\begin{array}{ll}\mathbf{m o l H}^{+} \text {-eq } & \left.\mathbf{t}^{-1}\right]\end{array}\right.}\end{array}$ & -28 & -24 & -29 & -31 & -37 & -26 & -35 & -28 & -37 & -32 & -30 & -34 & -21 & -31 & -26 & -23 & -29 & -36 & -44 & -32 \\
\hline \multirow{7}{*}{ 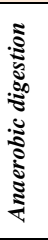 } & LUC & $0 \%$ & $0 \%$ & $0 \%$ & $0 \%$ & $0 \%$ & $0 \%$ & $0 \%$ & $0 \%$ & $0 \%$ & $0 \%$ & $0 \%$ & $0 \%$ & $0 \%$ & $0 \%$ & $0 \%$ & $0 \%$ & $0 \%$ & $0 \%$ & $0 \%$ & $0 \%$ \\
\hline & FP & $0 \%$ & $0 \%$ & $0 \%$ & $0 \%$ & $0 \%$ & $0 \%$ & $0 \%$ & $0 \%$ & $0 \%$ & $0 \%$ & $0 \%$ & $0 \%$ & $0 \%$ & $0 \%$ & $0 \%$ & $0 \%$ & $0 \%$ & $0 \%$ & $0 \%$ & $0 \%$ \\
\hline & $\begin{array}{l}\mathrm{PP} \\
\end{array}$ & $0 \%$ & $0 \%$ & $0 \%$ & $0 \%$ & $0 \%$ & $0 \%$ & $0 \%$ & $0 \%$ & $0 \%$ & $0 \%$ & $0 \%$ & $0 \%$ & $0 \%$ & $0 \%$ & $0 \%$ & $0 \%$ & $0 \%$ & $0 \%$ & $0 \%$ & $0 \%$ \\
\hline & AFP & $0 \%$ & $0 \%$ & $0 \%$ & $0 \%$ & $0 \%$ & $0 \%$ & $0 \%$ & $0 \%$ & $0 \%$ & $0 \%$ & $0 \%$ & $0 \%$ & $0 \%$ & $0 \%$ & $0 \%$ & $0 \%$ & $0 \%$ & $0 \%$ & $0 \%$ & $0 \%$ \\
\hline & TRCS & $0 \%$ & $0 \%$ & $0 \%$ & $0 \%$ & $0 \%$ & $0 \%$ & $0 \%$ & $0 \%$ & $0 \%$ & $0 \%$ & $0 \%$ & $0 \%$ & $0 \%$ & $0 \%$ & $0 \%$ & $0 \%$ & $0 \%$ & $0 \%$ & $0 \%$ & $0 \%$ \\
\hline & WM\&C & $0 \%$ & $0 \%$ & $0 \%$ & $0 \%$ & $0 \%$ & $0 \%$ & $0 \%$ & $0 \%$ & $0 \%$ & $0 \%$ & $0 \%$ & $0 \%$ & $0 \%$ & $0 \%$ & $0 \%$ & $0 \%$ & $0 \%$ & $0 \%$ & $0 \%$ & $0 \%$ \\
\hline & $\begin{array}{l}\text { Total } \\
{\left[\begin{array}{ll}\mathbf{m o l H}^{+} \text {eq } & \left.\mathbf{t}^{-1}\right]\end{array}\right.}\end{array}$ & 1.9 & 1.5 & 1.8 & 2.0 & 2.2 & 1.6 & 1.7 & 1.7 & 2.1 & 1.7 & 1.8 & 2.2 & 1.4 & 2.0 & 1.8 & 1.5 & 1.8 & 2.2 & 2.3 & 1.7 \\
\hline \multirow{7}{*}{ 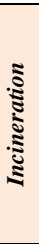 } & LUC & $0 \%$ & $0 \%$ & $0 \%$ & $0 \%$ & $0 \%$ & $0 \%$ & $0 \%$ & $0 \%$ & $0 \%$ & $0 \%$ & $0 \%$ & $0 \%$ & $0 \%$ & $0 \%$ & $0 \%$ & $0 \%$ & $0 \%$ & $0 \%$ & $0 \%$ & $0 \%$ \\
\hline & FP & $0 \%$ & $0 \%$ & $0 \%$ & $0 \%$ & $0 \%$ & $0 \%$ & $0 \%$ & $0 \%$ & $0 \%$ & $0 \%$ & $0 \%$ & $0 \%$ & $0 \%$ & $0 \%$ & $0 \%$ & $0 \%$ & $0 \%$ & $0 \%$ & $0 \%$ & $0 \%$ \\
\hline & PP & $0 \%$ & $0 \%$ & $0 \%$ & $0 \%$ & $0 \%$ & $0 \%$ & $0 \%$ & $0 \%$ & $0 \%$ & $0 \%$ & $0 \%$ & $0 \%$ & $0 \%$ & $0 \%$ & $0 \%$ & $0 \%$ & $0 \%$ & $0 \%$ & $0 \%$ & $0 \%$ \\
\hline & AFP & $0 \%$ & $0 \%$ & $0 \%$ & $0 \%$ & $0 \%$ & $0 \%$ & $0 \%$ & $0 \%$ & $0 \%$ & $0 \%$ & $0 \%$ & $0 \%$ & $0 \%$ & $0 \%$ & $0 \%$ & $0 \%$ & $0 \%$ & $0 \%$ & $0 \%$ & $0 \%$ \\
\hline & TRCS & $12 \%$ & $-6 \%$ & $7 \%$ & $-4 \%$ & $-6 \%$ & $5 \%$ & $4 \%$ & $4 \%$ & $-19 \%$ & $2 \%$ & $7 \%$ & $-44 \%$ & $4 \%$ & $9 \%$ & $5 \%$ & $3 \%$ & $4 \%$ & $-42 \%$ & $-28 \%$ & $3 \%$ \\
\hline & WM\&C & $88 \%$ & $106 \%$ & $93 \%$ & $104 \%$ & $106 \%$ & $95 \%$ & $96 \%$ & $96 \%$ & $119 \%$ & $98 \%$ & $93 \%$ & $144 \%$ & $96 \%$ & $91 \%$ & $95 \%$ & $97 \%$ & $96 \%$ & $142 \%$ & $128 \%$ & $97 \%$ \\
\hline & $\begin{array}{l}\text { Total } \\
{\left[\begin{array}{ll}\mathbf{m o l H}^{+} \text {-eq } & \left.\mathbf{t}^{-1}\right]\end{array}\right.}\end{array}$ & 0.040 & 0.077 & 0.063 & -0.11 & 0.083 & 0.089 & 0.12 & 0.12 & 0.025 & 0.22 & 0.072 & 0.011 & 0.11 & 0.051 & 0.97 & 0.14 & 0.12 & 0.011 & 0.017 & 0.16 \\
\hline \multicolumn{2}{|c|}{$\begin{array}{c}\text { Photochemical Ozone } \\
\text { Formation }\end{array}$} & & & & & & & & & & & & & & & & & & & & \\
\hline \multirow{7}{*}{ 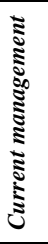 } & LUC & $23 \%$ & $25 \%$ & $21 \%$ & $24 \%$ & $23 \%$ & $24 \%$ & $20 \%$ & $22 \%$ & $22 \%$ & $18 \%$ & $22 \%$ & $22 \%$ & $25 \%$ & $22 \%$ & $24 \%$ & $25 \%$ & $22 \%$ & $22 \%$ & $21 \%$ & $27 \%$ \\
\hline & FP & $69 \%$ & $65 \%$ & $72 \%$ & $68 \%$ & $70 \%$ & $68 \%$ & $73 \%$ & $69 \%$ & $71 \%$ & $73 \%$ & $70 \%$ & $70 \%$ & $66 \%$ & $69 \%$ & $68 \%$ & $66 \%$ & $70 \%$ & $71 \%$ & $72 \%$ & $61 \%$ \\
\hline & PP & $1 \%$ & $1 \%$ & $1 \%$ & $1 \%$ & $1 \%$ & $1 \%$ & $3 \%$ & $2 \%$ & $1 \%$ & $2 \%$ & $1 \%$ & $1 \%$ & $2 \%$ & $2 \%$ & $1 \%$ & $1 \%$ & $2 \%$ & $1 \%$ & $1 \%$ & $1 \%$ \\
\hline & AFP & $0 \%$ & $0 \%$ & $0 \%$ & $0 \%$ & $0 \%$ & $0 \%$ & $0 \%$ & $0 \%$ & $0 \%$ & $0 \%$ & $0 \%$ & $0 \%$ & $0 \%$ & $0 \%$ & $0 \%$ & $0 \%$ & $0 \%$ & $0 \%$ & $0 \%$ & $6 \%$ \\
\hline & TRCS & $6 \%$ & $8 \%$ & $6 \%$ & $5 \%$ & $5 \%$ & $7 \%$ & $5 \%$ & $7 \%$ & $5 \%$ & $8 \%$ & $7 \%$ & $6 \%$ & $9 \%$ & $7 \%$ & $7 \%$ & $8 \%$ & $7 \%$ & $5 \%$ & $5 \%$ & $5 \%$ \\
\hline & WM\&C & $0 \%$ & $0 \%$ & $0 \%$ & $0 \%$ & $1 \%$ & $0 \%$ & $0 \%$ & $0 \%$ & $0 \%$ & $-1 \%$ & $0 \%$ & $1 \%$ & $-2 \%$ & $0 \%$ & $0 \%$ & $0 \%$ & $0 \%$ & $0 \%$ & $0 \%$ & $0 \%$ \\
\hline & $\begin{array}{l}\text { Total } \\
{\left[\mathrm{kgNMVOC}_{-\mathrm{eq}} \mathrm{t}^{-1}\right]}\end{array}$ & -4.7 & -3.1 & -4.4 & -4.3 & -2.9 & -2.8 & -3.8 & -3.6 & -4.3 & -3.1 & -2.9 & -2.2 & -0.88 & -2.5 & -2.1 & -3.5 & -3.3 & -4.1 & -4.8 & -3.5 \\
\hline \multirow{7}{*}{ 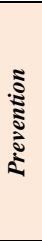 } & LUC & $16 \%$ & $18 \%$ & $16 \%$ & $16 \%$ & $16 \%$ & $15 \%$ & $11 \%$ & $15 \%$ & $15 \%$ & $12 \%$ & $15 \%$ & $16 \%$ & $16 \%$ & $15 \%$ & $17 \%$ & $17 \%$ & $15 \%$ & $16 \%$ & $14 \%$ & $15 \%$ \\
\hline & FP & $74 \%$ & $72 \%$ & $74 \%$ & $75 \%$ & $75 \%$ & $74 \%$ & $79 \%$ & $75 \%$ & $77 \%$ & $78 \%$ & $75 \%$ & $76 \%$ & $72 \%$ & $75 \%$ & $72 \%$ & $72 \%$ & $75 \%$ & $75 \%$ & $79 \%$ & $76 \%$ \\
\hline & PP & $3 \%$ & $2 \%$ & $3 \%$ & $3 \%$ & $2 \%$ & $2 \%$ & $3 \%$ & $2 \%$ & $3 \%$ & $2 \%$ & $2 \%$ & $2 \%$ & $2 \%$ & $2 \%$ & $2 \%$ & $2 \%$ & $3 \%$ & $3 \%$ & $2 \%$ & $2 \%$ \\
\hline & AFP & $0 \%$ & $0 \%$ & $0 \%$ & $0 \%$ & $0 \%$ & $0 \%$ & $0 \%$ & $0 \%$ & $0 \%$ & $0 \%$ & $0 \%$ & $0 \%$ & $0 \%$ & $0 \%$ & $0 \%$ & $0 \%$ & $0 \%$ & $0 \%$ & $0 \%$ & $0 \%$ \\
\hline & TRCS & $8 \%$ & $8 \%$ & $7 \%$ & $7 \%$ & $6 \%$ & $8 \%$ & $7 \%$ & $8 \%$ & $6 \%$ & $8 \%$ & $7 \%$ & $6 \%$ & $9 \%$ & $7 \%$ & $8 \%$ & $9 \%$ & $8 \%$ & $6 \%$ & $5 \%$ & $7 \%$ \\
\hline & WM\&C & $0 \%$ & $0 \%$ & $0 \%$ & $0 \%$ & $0 \%$ & $0 \%$ & $0 \%$ & $0 \%$ & $0 \%$ & $0 \%$ & $0 \%$ & $0 \%$ & $0 \%$ & $0 \%$ & $0 \%$ & $0 \%$ & $0 \%$ & $0 \%$ & $0 \%$ & $0 \%$ \\
\hline & $\begin{array}{l}\text { Total } \\
{\left[\text { kgNMVOC }_{\text {-et }} t^{-1}\right]}\end{array}$ & -6.3 & -6.1 & -6.6 & -6.8 & -8.0 & -6.0 & -6.5 & -6.3 & -7.9 & -6.5 & -6.5 & -7.2 & -5.1 & -7.0 & -6.0 & -5.7 & -6.6 & -7.6 & -9.4 & -7.8 \\
\hline
\end{tabular}




\begin{tabular}{|c|c|c|c|c|c|c|c|c|c|c|c|c|c|c|c|c|c|c|c|c|c|}
\hline \multirow{7}{*}{ 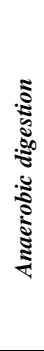 } & LUC & $0 \%$ & $0 \%$ & $0 \%$ & $0 \%$ & $0 \%$ & $0 \%$ & $0 \%$ & $0 \%$ & $0 \%$ & $0 \%$ & $0 \%$ & $0 \%$ & $0 \%$ & $0 \%$ & $0 \%$ & $0 \%$ & $0 \%$ & $0 \%$ & $0 \%$ & $0 \%$ \\
\hline & FP & $0 \%$ & $0 \%$ & $0 \%$ & $0 \%$ & $0 \%$ & $0 \%$ & $0 \%$ & $0 \%$ & $0 \%$ & $0 \%$ & $0 \%$ & $0 \%$ & $0 \%$ & $0 \%$ & $0 \%$ & $0 \%$ & $0 \%$ & $0 \%$ & $0 \%$ & $0 \%$ \\
\hline & PP & $0 \%$ & $0 \%$ & $0 \%$ & $0 \%$ & $0 \%$ & $0 \%$ & $0 \%$ & $0 \%$ & $0 \%$ & $0 \%$ & $0 \%$ & $0 \%$ & $0 \%$ & $0 \%$ & $0 \%$ & $0 \%$ & $0 \%$ & $0 \%$ & $0 \%$ & $0 \%$ \\
\hline & AFP & $0 \%$ & $0 \%$ & $0 \%$ & $0 \%$ & $0 \%$ & $0 \%$ & $0 \%$ & $0 \%$ & $0 \%$ & $0 \%$ & $0 \%$ & $0 \%$ & $0 \%$ & $0 \%$ & $0 \%$ & $0 \%$ & $0 \%$ & $0 \%$ & $0 \%$ & $0 \%$ \\
\hline & TRCS & $-15 \%$ & $0 \%$ & $\begin{array}{r}1253 \\
\%\end{array}$ & $-2 \%$ & $-2 \%$ & $9 \%$ & $5 \%$ & $5 \%$ & $-3 \%$ & $2 \%$ & $-29 \%$ & $-3 \%$ & $4 \%$ & $-6 \%$ & $10 \%$ & $3 \%$ & $6 \%$ & $-2 \%$ & $-3 \%$ & $2 \%$ \\
\hline & WM\&C & $115 \%$ & $100 \%$ & $\begin{array}{r}12153 \\
\% \\
\end{array}$ & $102 \%$ & $102 \%$ & $91 \%$ & $95 \%$ & $95 \%$ & $103 \%$ & $98 \%$ & $129 \%$ & $103 \%$ & $96 \%$ & $106 \%$ & $90 \%$ & $97 \%$ & $94 \%$ & $102 \%$ & $103 \%$ & $98 \%$ \\
\hline & $\begin{array}{l}\text { Total } \\
{\left[\text { kgNMVOC-eq }^{-1}{ }^{-1}\right]}\end{array}$ & $\begin{array}{r}4.6 \mathrm{E}- \\
03 \\
\end{array}$ & $\begin{array}{r}1.8 \mathrm{E}- \\
01\end{array}$ & $\begin{array}{r}5.5 \mathrm{E}- \\
05 \\
\end{array}$ & $\begin{array}{r}- \\
3.9 \mathrm{E}- \\
02\end{array}$ & $\begin{array}{r}3.9 \mathrm{E}- \\
02 \\
\end{array}$ & $\begin{array}{r}7.4 \mathrm{E}- \\
03 \\
\end{array}$ & $\begin{array}{r}1.4 \mathrm{E}- \\
02 \\
\end{array}$ & $\begin{array}{r}1.4 \mathrm{E}- \\
02 \\
\end{array}$ & $\begin{array}{r}2.1 \mathrm{E}- \\
02 \\
\end{array}$ & $\begin{array}{r}4.1 \mathrm{E}- \\
02\end{array}$ & $\begin{array}{r}2.4 \mathrm{E}- \\
03\end{array}$ & $\begin{array}{r}- \\
2.7 \mathrm{E}- \\
02\end{array}$ & $\begin{array}{r}1.7 \mathrm{E}- \\
02\end{array}$ & $\begin{array}{r}1.2 \mathrm{E}- \\
02\end{array}$ & $\begin{array}{r}6.6 \mathrm{E}- \\
03\end{array}$ & $\begin{array}{r}2.2 \mathrm{E}- \\
02\end{array}$ & $\begin{array}{r}1.2 \mathrm{E}- \\
02\end{array}$ & $\begin{array}{r}3.0 \mathrm{E}- \\
02\end{array}$ & $\begin{array}{r}2.4 \mathrm{E}- \\
02\end{array}$ & $\begin{array}{r}3.7 \mathrm{E}- \\
02\end{array}$ \\
\hline \multirow{7}{*}{ 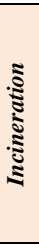 } & LUC & $0 \%$ & $0 \%$ & $0 \%$ & $0 \%$ & $0 \%$ & $0 \%$ & $0 \%$ & $0 \%$ & $0 \%$ & $0 \%$ & $0 \%$ & $0 \%$ & $0 \%$ & $0 \%$ & $0 \%$ & $0 \%$ & $0 \%$ & $0 \%$ & $0 \%$ & $0 \%$ \\
\hline & FP & $0 \%$ & $0 \%$ & $0 \%$ & $0 \%$ & $0 \%$ & $0 \%$ & $0 \%$ & $0 \%$ & $0 \%$ & $0 \%$ & $0 \%$ & $0 \%$ & $0 \%$ & $0 \%$ & $0 \%$ & $0 \%$ & $0 \%$ & $0 \%$ & $0 \%$ & $0 \%$ \\
\hline & PP & $0 \%$ & $0 \%$ & $0 \%$ & $0 \%$ & $0 \%$ & $0 \%$ & $0 \%$ & $0 \%$ & $0 \%$ & $0 \%$ & $0 \%$ & $0 \%$ & $0 \%$ & $0 \%$ & $0 \%$ & $0 \%$ & $0 \%$ & $0 \%$ & $0 \%$ & $0 \%$ \\
\hline & AFP & $0 \%$ & $0 \%$ & $0 \%$ & $0 \%$ & $0 \%$ & $0 \%$ & $0 \%$ & $0 \%$ & $0 \%$ & $0 \%$ & $0 \%$ & $0 \%$ & $0 \%$ & $0 \%$ & $0 \%$ & $0 \%$ & $0 \%$ & $0 \%$ & $0 \%$ & $0 \%$ \\
\hline & TRCS & $1 \%$ & $1 \%$ & $1 \%$ & $1 \%$ & $1 \%$ & $1 \%$ & $1 \%$ & $1 \%$ & $1 \%$ & $0 \%$ & $1 \%$ & $1 \%$ & $1 \%$ & $1 \%$ & $1 \%$ & $1 \%$ & $1 \%$ & $1 \%$ & $1 \%$ & $1 \%$ \\
\hline & WM\&C & $99 \%$ & $99 \%$ & $99 \%$ & $99 \%$ & $99 \%$ & $99 \%$ & $99 \%$ & $99 \%$ & $99 \%$ & $100 \%$ & $99 \%$ & $99 \%$ & $99 \%$ & $99 \%$ & $99 \%$ & $99 \%$ & $99 \%$ & $99 \%$ & $99 \%$ & $99 \%$ \\
\hline & $\begin{array}{l}\text { Total } \\
{\left[\operatorname{kgNMVOC}_{-\mathrm{eq}} \mathrm{t}^{-1}\right]}\end{array}$ & 0.58 & 0.54 & 0.59 & 0.53 & 0.54 & 0.60 & 0.61 & 0.61 & 0.56 & 0.65 & 0.59 & 0.57 & 0.61 & 0.59 & 0.60 & 0.62 & 0.61 & 0.57 & 0.56 & 0.63 \\
\hline \multicolumn{2}{|c|}{ Particulate matter } & & & & & & & & & & & & & & & & & & & & \\
\hline \multirow{7}{*}{ 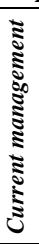 } & LUC & $18 \%$ & $20 \%$ & $16 \%$ & $19 \%$ & $18 \%$ & $18 \%$ & $14 \%$ & $17 \%$ & $17 \%$ & $13 \%$ & $17 \%$ & $16 \%$ & $19 \%$ & $17 \%$ & $18 \%$ & $20 \%$ & $16 \%$ & $16 \%$ & $15 \%$ & $19 \%$ \\
\hline & FP & $77 \%$ & $74 \%$ & $80 \%$ & $76 \%$ & $78 \%$ & $76 \%$ & $81 \%$ & $78 \%$ & $79 \%$ & $82 \%$ & $78 \%$ & $78 \%$ & $70 \%$ & $78 \%$ & $75 \%$ & $74 \%$ & $78 \%$ & $79 \%$ & $81 \%$ & $66 \%$ \\
\hline & $\begin{array}{l}\mathrm{PP} \\
\end{array}$ & $1 \%$ & $1 \%$ & $1 \%$ & $1 \%$ & $1 \%$ & $1 \%$ & $1 \%$ & $1 \%$ & $1 \%$ & $1 \%$ & $1 \%$ & $1 \%$ & $1 \%$ & $1 \%$ & $1 \%$ & $1 \%$ & $1 \%$ & $1 \%$ & $1 \%$ & $1 \%$ \\
\hline & AFP & $0 \%$ & $0 \%$ & $0 \%$ & $0 \%$ & $0 \%$ & $0 \%$ & $0 \%$ & $0 \%$ & $0 \%$ & $0 \%$ & $0 \%$ & $0 \%$ & $0 \%$ & $0 \%$ & $0 \%$ & $0 \%$ & $0 \%$ & $0 \%$ & $0 \%$ & $11 \%$ \\
\hline & TRCS & $4 \%$ & $5 \%$ & $3 \%$ & $3 \%$ & $3 \%$ & $4 \%$ & $3 \%$ & $4 \%$ & $3 \%$ & $4 \%$ & $4 \%$ & $3 \%$ & $5 \%$ & $4 \%$ & $4 \%$ & $5 \%$ & $4 \%$ & $3 \%$ & $3 \%$ & $3 \%$ \\
\hline & WM\&C & $0 \%$ & $1 \%$ & $0 \%$ & $1 \%$ & $1 \%$ & $1 \%$ & $0 \%$ & $0 \%$ & $0 \%$ & $0 \%$ & $1 \%$ & $1 \%$ & $5 \%$ & $1 \%$ & $1 \%$ & $1 \%$ & $0 \%$ & $0 \%$ & $0 \%$ & $0 \%$ \\
\hline & $\begin{array}{l}\text { Total } \\
{\left[\text { kgPM2.5-e }^{-1} \mathrm{t}^{-1}\right]}\end{array}$ & -0.99 & -0.63 & -0.96 & -0.91 & -0.62 & -0.58 & -0.87 & -0.78 & -0.94 & -0.73 & -0.62 & -0.49 & -0.19 & -0.54 & -0.44 & -0.71 & -0.72 & -0.89 & -1.1 & -0.79 \\
\hline \multirow{7}{*}{ 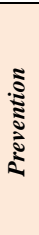 } & LUC & $8 \%$ & $9 \%$ & $7 \%$ & $8 \%$ & $8 \%$ & $7 \%$ & $5 \%$ & $7 \%$ & $7 \%$ & $5 \%$ & $7 \%$ & $7 \%$ & $7 \%$ & $7 \%$ & $8 \%$ & $8 \%$ & $7 \%$ & $7 \%$ & $7 \%$ & $7 \%$ \\
\hline & FP & $88 \%$ & $87 \%$ & $89 \%$ & $89 \%$ & $89 \%$ & $89 \%$ & $92 \%$ & $89 \%$ & $90 \%$ & $91 \%$ & $90 \%$ & $89 \%$ & $89 \%$ & $89 \%$ & $88 \%$ & $88 \%$ & $89 \%$ & $89 \%$ & $90 \%$ & $89 \%$ \\
\hline & $\mathrm{PP}$ & $1 \%$ & $1 \%$ & $1 \%$ & $1 \%$ & $1 \%$ & $1 \%$ & $1 \%$ & $1 \%$ & $1 \%$ & $1 \%$ & $1 \%$ & $1 \%$ & $1 \%$ & $1 \%$ & $1 \%$ & $1 \%$ & $1 \%$ & $1 \%$ & $1 \%$ & $1 \%$ \\
\hline & AFP & $0 \%$ & $0 \%$ & $0 \%$ & $0 \%$ & $0 \%$ & $0 \%$ & $0 \%$ & $0 \%$ & $0 \%$ & $0 \%$ & $0 \%$ & $0 \%$ & $0 \%$ & $0 \%$ & $0 \%$ & $0 \%$ & $0 \%$ & $0 \%$ & $0 \%$ & $0 \%$ \\
\hline & TRCS & $3 \%$ & $3 \%$ & $3 \%$ & $2 \%$ & $2 \%$ & $3 \%$ & $2 \%$ & $3 \%$ & $2 \%$ & $3 \%$ & $2 \%$ & $2 \%$ & $3 \%$ & $2 \%$ & $3 \%$ & $3 \%$ & $3 \%$ & $2 \%$ & $2 \%$ & $2 \%$ \\
\hline & WM\&C & $0 \%$ & $0 \%$ & $0 \%$ & $0 \%$ & $0 \%$ & $0 \%$ & $0 \%$ & $0 \%$ & $0 \%$ & $0 \%$ & $0 \%$ & $0 \%$ & $0 \%$ & $0 \%$ & $0 \%$ & $0 \%$ & $0 \%$ & $0 \%$ & $0 \%$ & $0 \%$ \\
\hline & $\begin{array}{l}\text { Total } \\
{\left[\mathrm{kgPM} 2.5 \text {-eq }^{-1}\right]}\end{array}$ & -2.1 & -2.0 & -2.3 & -2.3 & -2.7 & -2.1 & -2.5 & -2.3 & -2.7 & -2.5 & -2.4 & -2.5 & -1.8 & -2.5 & -2.1 & -1.9 & -2.3 & -2.7 & -3.2 & -2.6 \\
\hline \multirow{7}{*}{ 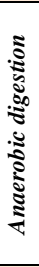 } & LUC & $0 \%$ & $0 \%$ & $0 \%$ & $0 \%$ & $0 \%$ & $0 \%$ & $0 \%$ & $0 \%$ & $0 \%$ & $0 \%$ & $0 \%$ & $0 \%$ & $0 \%$ & $0 \%$ & $0 \%$ & $0 \%$ & $0 \%$ & $0 \%$ & $0 \%$ & $0 \%$ \\
\hline & FP & $0 \%$ & $0 \%$ & $0 \%$ & $0 \%$ & $0 \%$ & $0 \%$ & $0 \%$ & $0 \%$ & $0 \%$ & $0 \%$ & $0 \%$ & $0 \%$ & $0 \%$ & $0 \%$ & $0 \%$ & $0 \%$ & $0 \%$ & $0 \%$ & $0 \%$ & $0 \%$ \\
\hline & PP & $0 \%$ & $0 \%$ & $0 \%$ & $0 \%$ & $0 \%$ & $0 \%$ & $0 \%$ & $0 \%$ & $0 \%$ & $0 \%$ & $0 \%$ & $0 \%$ & $0 \%$ & $0 \%$ & $0 \%$ & $0 \%$ & $0 \%$ & $0 \%$ & $0 \%$ & $0 \%$ \\
\hline & AFP & $0 \%$ & $0 \%$ & $0 \%$ & $0 \%$ & $0 \%$ & $0 \%$ & $0 \%$ & $0 \%$ & $0 \%$ & $0 \%$ & $0 \%$ & $0 \%$ & $0 \%$ & $0 \%$ & $0 \%$ & $0 \%$ & $0 \%$ & $0 \%$ & $0 \%$ & $0 \%$ \\
\hline & TRCS & $-1 \%$ & $0 \%$ & $0 \%$ & $0 \%$ & $-1 \%$ & $0 \%$ & $-1 \%$ & $-1 \%$ & $-1 \%$ & $-2 \%$ & $-1 \%$ & $-1 \%$ & $0 \%$ & $-1 \%$ & $-1 \%$ & $0 \%$ & $-1 \%$ & $-1 \%$ & $-1 \%$ & $-1 \%$ \\
\hline & WM\&C & $101 \%$ & $100 \%$ & $100 \%$ & $100 \%$ & $101 \%$ & $100 \%$ & $101 \%$ & $101 \%$ & $101 \%$ & $102 \%$ & $101 \%$ & $101 \%$ & $100 \%$ & $101 \%$ & $101 \%$ & $100 \%$ & $101 \%$ & $101 \%$ & $101 \%$ & $101 \%$ \\
\hline & 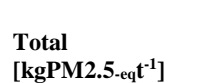 & $\begin{array}{r}\text { 7.1E- } \\
03\end{array}$ & $\begin{array}{r}1.4 \mathrm{E}- \\
02\end{array}$ & $\begin{array}{r}8.3 \mathrm{E}- \\
03\end{array}$ & $\begin{array}{r}1.1 \mathrm{E}- \\
02\end{array}$ & $\begin{array}{r}7.6 \mathrm{E}- \\
03\end{array}$ & $\begin{array}{r}9.2 \mathrm{E}- \\
03\end{array}$ & $\begin{array}{r}-\overline{-} \\
7.9 \mathrm{E}- \\
03\end{array}$ & $\begin{array}{r}7.4 \mathrm{E}- \\
03\end{array}$ & $\begin{array}{r}7.1 \mathrm{E}- \\
03\end{array}$ & $\begin{array}{r}1.9 \mathrm{E}- \\
03\end{array}$ & $\begin{array}{r}7.5 \mathrm{E}- \\
03\end{array}$ & $\begin{array}{r}6.7 \mathrm{E}- \\
03\end{array}$ & $\begin{array}{r}1.1 \mathrm{E}- \\
02\end{array}$ & $\begin{array}{r}7.9 \mathrm{E}- \\
03\end{array}$ & $\begin{array}{r}7.6 \mathrm{E}- \\
03\end{array}$ & $\begin{array}{r}9.5 \mathrm{E}- \\
03\end{array}$ & $\begin{array}{r}6.2 \mathrm{E}- \\
03\end{array}$ & $\begin{array}{r}6.8 \mathrm{E}- \\
03\end{array}$ & $\begin{array}{r}4.4 \mathrm{E}- \\
03\end{array}$ & $\begin{array}{r}3.7 \mathrm{E}- \\
03\end{array}$ \\
\hline \multirow{6}{*}{ 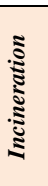 } & LUC & $0 \%$ & $0 \%$ & $0 \%$ & $0 \%$ & $0 \%$ & $0 \%$ & $0 \%$ & $0 \%$ & $0 \%$ & $0 \%$ & $0 \%$ & $0 \%$ & $0 \%$ & $0 \%$ & $0 \%$ & $0 \%$ & $0 \%$ & $0 \%$ & $0 \%$ & $0 \%$ \\
\hline & FP & $0 \%$ & $0 \%$ & $0 \%$ & $0 \%$ & $0 \%$ & $0 \%$ & $0 \%$ & $0 \%$ & $0 \%$ & $0 \%$ & $0 \%$ & $0 \%$ & $0 \%$ & $0 \%$ & $0 \%$ & $0 \%$ & $0 \%$ & $0 \%$ & $0 \%$ & $0 \%$ \\
\hline & PP & $0 \%$ & $0 \%$ & $0 \%$ & $0 \%$ & $0 \%$ & $0 \%$ & $0 \%$ & $0 \%$ & $0 \%$ & $0 \%$ & $0 \%$ & $0 \%$ & $0 \%$ & $0 \%$ & $0 \%$ & $0 \%$ & $0 \%$ & $0 \%$ & $0 \%$ & $0 \%$ \\
\hline & AFP & $0 \%$ & $0 \%$ & $0 \%$ & $0 \%$ & $0 \%$ & $0 \%$ & $0 \%$ & $0 \%$ & $0 \%$ & $0 \%$ & $0 \%$ & $0 \%$ & $0 \%$ & $0 \%$ & $0 \%$ & $0 \%$ & $0 \%$ & $0 \%$ & $0 \%$ & $0 \%$ \\
\hline & TRCS & $-1 \%$ & $-1 \%$ & $-1 \%$ & $-1 \%$ & $-1 \%$ & $-1 \%$ & $-1 \%$ & $-1 \%$ & $-1 \%$ & $-2 \%$ & $-1 \%$ & $-1 \%$ & $-1 \%$ & $-1 \%$ & $-1 \%$ & $-1 \%$ & $-1 \%$ & $-1 \%$ & $-1 \%$ & $-1 \%$ \\
\hline & WM\&C & $101 \%$ & $101 \%$ & $101 \%$ & $101 \%$ & $101 \%$ & $101 \%$ & $101 \%$ & $101 \%$ & $101 \%$ & $102 \%$ & $101 \%$ & $101 \%$ & $101 \%$ & $101 \%$ & $101 \%$ & $101 \%$ & $101 \%$ & $101 \%$ & $101 \%$ & $101 \%$ \\
\hline
\end{tabular}




\begin{tabular}{|c|c|c|c|c|c|c|c|c|c|c|c|c|c|c|c|c|c|c|c|c|c|}
\hline & 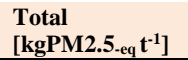 & 0.020 & 0.027 & 0.019 & 0.028 & 0.027 & 0.017 & 0.016 & 0.016 & 0.024 & 0.010 & 0.018 & 0.023 & 0.016 & $0.020^{-}$ & 0.017 & 0.015 & 0.016 & 0.023 & 0.023 & 0.013 \\
\hline \multicolumn{22}{|c|}{$\begin{array}{c}\text { Aquatic Eutrophication } \\
\text { Nitrogen }\end{array}$} \\
\hline \multirow{7}{*}{ 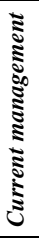 } & LUC & $33 \%$ & $38 \%$ & $29 \%$ & $35 \%$ & $39 \%$ & $36 \%$ & $28 \%$ & $33 \%$ & $32 \%$ & $27 \%$ & $35 \%$ & $40 \%$ & $86 \%$ & $37 \%$ & $42 \%$ & $36 \%$ & $33 \%$ & $33 \%$ & $29 \%$ & $36 \%$ \\
\hline & FP & $72 \%$ & $72 \%$ & $77 \%$ & $73 \%$ & $87 \%$ & $78 \%$ & $80 \%$ & $75 \%$ & $78 \%$ & $84 \%$ & $83 \%$ & $99 \%$ & $160 \%$ & $89 \%$ & $88 \%$ & $70 \%$ & $79 \%$ & $80 \%$ & $79 \%$ & $64 \%$ \\
\hline & PP & $1 \%$ & $1 \%$ & $1 \%$ & $1 \%$ & $1 \%$ & $1 \%$ & $0 \%$ & $1 \%$ & $1 \%$ & $0 \%$ & $1 \%$ & $1 \%$ & $2 \%$ & $1 \%$ & $1 \%$ & $1 \%$ & $1 \%$ & $1 \%$ & $1 \%$ & $1 \%$ \\
\hline & AFP & $0 \%$ & $0 \%$ & $0 \%$ & $0 \%$ & $0 \%$ & $0 \%$ & $0 \%$ & $0 \%$ & $0 \%$ & $0 \%$ & $0 \%$ & $0 \%$ & $0 \%$ & $0 \%$ & $0 \%$ & $0 \%$ & $0 \%$ & $0 \%$ & $0 \%$ & $7 \%$ \\
\hline & TRCS & $1 \%$ & $1 \%$ & $1 \%$ & $1 \%$ & $1 \%$ & $1 \%$ & $1 \%$ & $1 \%$ & $1 \%$ & $1 \%$ & $1 \%$ & $1 \%$ & $2 \%$ & $1 \%$ & $1 \%$ & $1 \%$ & $1 \%$ & $1 \%$ & $1 \%$ & $1 \%$ \\
\hline & WM\&C & $-6 \%$ & $-12 \%$ & $-8 \%$ & $-10 \%$ & $-27 \%$ & $-16 \%$ & $-8 \%$ & $-9 \%$ & $-11 \%$ & $-13 \%$ & $-19 \%$ & $-41 \%$ & $150 \%$ & $-28 \%$ & $-32 \%$ & $-8 \%$ & $-14 \%$ & $-13 \%$ & $-10 \%$ & $-8 \%$ \\
\hline & Total $\left[\mathrm{kgN}_{\text {-eq }}{ }^{-1}\right]$ & -13 & -7.7 & -12 & -11 & -6.7 & -6.8 & -10 & -9.4 & -11 & -8.0 & -6.9 & -4.6 & -0.98 & -5.5 & -4.6 & -8.9 & -8.3 & -10 & -13 & -10 \\
\hline \multirow{7}{*}{ 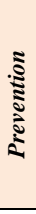 } & LUC & $21 \%$ & $24 \%$ & $21 \%$ & $20 \%$ & $23 \%$ & $20 \%$ & $13 \%$ & $20 \%$ & $20 \%$ & $15 \%$ & $19 \%$ & $19 \%$ & $21 \%$ & $19 \%$ & $23 \%$ & $23 \%$ & $20 \%$ & $21 \%$ & $19 \%$ & $23 \%$ \\
\hline & FP & $77 \%$ & $74 \%$ & $78 \%$ & $79 \%$ & $76 \%$ & $78 \%$ & $86 \%$ & $79 \%$ & $79 \%$ & $84 \%$ & $80 \%$ & $80 \%$ & $78 \%$ & $80 \%$ & $75 \%$ & $75 \%$ & $79 \%$ & $78 \%$ & $80 \%$ & $76 \%$ \\
\hline & PP & $0 \%$ & $0 \%$ & $0 \%$ & $0 \%$ & $0 \%$ & $0 \%$ & $0 \%$ & $0 \%$ & $0 \%$ & $0 \%$ & $0 \%$ & $0 \%$ & $0 \%$ & $0 \%$ & $0 \%$ & $0 \%$ & $0 \%$ & $0 \%$ & $0 \%$ & $0 \%$ \\
\hline & AFP & $0 \%$ & $0 \%$ & $0 \%$ & $0 \%$ & $0 \%$ & $0 \%$ & $0 \%$ & $0 \%$ & $0 \%$ & $0 \%$ & $0 \%$ & $0 \%$ & $0 \%$ & $0 \%$ & $0 \%$ & $0 \%$ & $0 \%$ & $0 \%$ & $0 \%$ & $0 \%$ \\
\hline & TRCS & $1 \%$ & $1 \%$ & $1 \%$ & $1 \%$ & $1 \%$ & $1 \%$ & $1 \%$ & $1 \%$ & $1 \%$ & $1 \%$ & $1 \%$ & $1 \%$ & $1 \%$ & $1 \%$ & $1 \%$ & $1 \%$ & $1 \%$ & $1 \%$ & $1 \%$ & $1 \%$ \\
\hline & WM\&C & $0 \%$ & $0 \%$ & $0 \%$ & $0 \%$ & $0 \%$ & $0 \%$ & $0 \%$ & $0 \%$ & $0 \%$ & $0 \%$ & $0 \%$ & $0 \%$ & $0 \%$ & $0 \%$ & $0 \%$ & $0 \%$ & $0 \%$ & $0 \%$ & $0 \%$ & $0 \%$ \\
\hline & Total $\left[\mathrm{kgN}_{\text {-eq }} \mathrm{t}^{-1}\right]$ & -18 & -17 & -19 & -20 & -22 & -17 & -24 & -18 & -22 & -19 & -19 & -22 & -15 & -21 & -17 & -15 & -19 & -22 & -26 & -20 \\
\hline \multirow{7}{*}{ 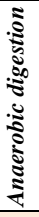 } & LUC & $0 \%$ & $0 \%$ & $0 \%$ & $0 \%$ & $0 \%$ & $0 \%$ & $0 \%$ & $0 \%$ & $0 \%$ & $0 \%$ & $0 \%$ & $0 \%$ & $0 \%$ & $0 \%$ & $0 \%$ & $0 \%$ & $0 \%$ & $0 \%$ & $0 \%$ & $0 \%$ \\
\hline & FP & $0 \%$ & $0 \%$ & $0 \%$ & $0 \%$ & $0 \%$ & $0 \%$ & $0 \%$ & $0 \%$ & $0 \%$ & $0 \%$ & $0 \%$ & $0 \%$ & $0 \%$ & $0 \%$ & $0 \%$ & $0 \%$ & $0 \%$ & $0 \%$ & $0 \%$ & $0 \%$ \\
\hline & $\mathrm{PP}$ & $0 \%$ & $0 \%$ & $0 \%$ & $0 \%$ & $0 \%$ & $0 \%$ & $0 \%$ & $0 \%$ & $0 \%$ & $0 \%$ & $0 \%$ & $0 \%$ & $0 \%$ & $0 \%$ & $0 \%$ & $0 \%$ & $0 \%$ & $0 \%$ & $0 \%$ & $0 \%$ \\
\hline & AFP & $0 \%$ & $0 \%$ & $0 \%$ & $0 \%$ & $0 \%$ & $0 \%$ & $0 \%$ & $0 \%$ & $0 \%$ & $0 \%$ & $0 \%$ & $0 \%$ & $0 \%$ & $0 \%$ & $0 \%$ & $0 \%$ & $0 \%$ & $0 \%$ & $0 \%$ & $0 \%$ \\
\hline & TRCS & $0 \%$ & $0 \%$ & $0 \%$ & $0 \%$ & $0 \%$ & $0 \%$ & $0 \%$ & $0 \%$ & $0 \%$ & $0 \%$ & $0 \%$ & $0 \%$ & $0 \%$ & $0 \%$ & $0 \%$ & $0 \%$ & $0 \%$ & $0 \%$ & $0 \%$ & $0 \%$ \\
\hline & WM\&C & $100 \%$ & $100 \%$ & $100 \%$ & $100 \%$ & $100 \%$ & $100 \%$ & $100 \%$ & $100 \%$ & $100 \%$ & $100 \%$ & $100 \%$ & $100 \%$ & $100 \%$ & $100 \%$ & $100 \%$ & $100 \%$ & $100 \%$ & $100 \%$ & $100 \%$ & $100 \%$ \\
\hline & Total $\left[\mathrm{kgN}-\right.$-eq $\left.\mathrm{t}^{-1}\right]$ & 2.3 & 2.0 & 2.2 & 2.5 & 2.7 & 2.0 & 2.1 & 2.0 & 2.5 & 2.0 & 2.2 & 2.6 & 1.8 & 2.4 & 2.1 & 1.8 & 2.2 & 2.7 & 2.7 & 1.9 \\
\hline \multirow{7}{*}{ 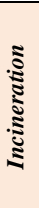 } & LUC & $0 \%$ & $0 \%$ & $0 \%$ & $0 \%$ & $0 \%$ & $0 \%$ & $0 \%$ & $0 \%$ & $0 \%$ & $0 \%$ & $0 \%$ & $0 \%$ & $0 \%$ & $0 \%$ & $0 \%$ & $0 \%$ & $0 \%$ & $0 \%$ & $0 \%$ & $0 \%$ \\
\hline & FP & $0 \%$ & $0 \%$ & $0 \%$ & $0 \%$ & $0 \%$ & $0 \%$ & $0 \%$ & $0 \%$ & $0 \%$ & $0 \%$ & $0 \%$ & $0 \%$ & $0 \%$ & $0 \%$ & $0 \%$ & $0 \%$ & $0 \%$ & $0 \%$ & $0 \%$ & $0 \%$ \\
\hline & PP & $0 \%$ & $0 \%$ & $0 \%$ & $0 \%$ & $0 \%$ & $0 \%$ & $0 \%$ & $0 \%$ & $0 \%$ & $0 \%$ & $0 \%$ & $0 \%$ & $0 \%$ & $0 \%$ & $0 \%$ & $0 \%$ & $0 \%$ & $0 \%$ & $0 \%$ & $0 \%$ \\
\hline & AFP & $0 \%$ & $0 \%$ & $0 \%$ & $0 \%$ & $0 \%$ & $0 \%$ & $0 \%$ & $0 \%$ & $0 \%$ & $0 \%$ & $0 \%$ & $0 \%$ & $0 \%$ & $0 \%$ & $0 \%$ & $0 \%$ & $0 \%$ & $0 \%$ & $0 \%$ & $0 \%$ \\
\hline & TRCS & $0 \%$ & $0 \%$ & $0 \%$ & $0 \%$ & $0 \%$ & $0 \%$ & $0 \%$ & $0 \%$ & $0 \%$ & $0 \%$ & $0 \%$ & $0 \%$ & $0 \%$ & $0 \%$ & $0 \%$ & $0 \%$ & $0 \%$ & $0 \%$ & $0 \%$ & $0 \%$ \\
\hline & WM\&C & $100 \%$ & $100 \%$ & $100 \%$ & $100 \%$ & $100 \%$ & $100 \%$ & $100 \%$ & $100 \%$ & $100 \%$ & $100 \%$ & $100 \%$ & $100 \%$ & $100 \%$ & $100 \%$ & $100 \%$ & $100 \%$ & $100 \%$ & $100 \%$ & $100 \%$ & $100 \%$ \\
\hline & Total $\left[\mathrm{kgN}_{\text {-eq }} \mathrm{t}^{-1}\right]$ & 0.27 & 0.26 & 0.27 & 0.26 & 0.26 & 0.28 & 0.28 & 0.28 & 0.27 & 0.28 & 0.27 & 0.27 & 0.28 & 0.27 & 0.28 & 0.28 & 0.28 & 0.27 & 0.27 & 0.28 \\
\hline \multicolumn{22}{|c|}{$\begin{array}{c}\text { Aquatic Eutrophication } \\
\text { Phosphorus }\end{array}$} \\
\hline \multirow{7}{*}{ Е } & LUC & $6 \%$ & $6 \%$ & $5 \%$ & $6 \%$ & $6 \%$ & $6 \%$ & $6 \%$ & $6 \%$ & $6 \%$ & $5 \%$ & $6 \%$ & $6 \%$ & $6 \%$ & $6 \%$ & $6 \%$ & $6 \%$ & $6 \%$ & $6 \%$ & $5 \%$ & $7 \%$ \\
\hline & FP & $93 \%$ & $92 \%$ & $94 \%$ & $92 \%$ & $92 \%$ & $92 \%$ & $92 \%$ & $92 \%$ & $93 \%$ & $92 \%$ & $92 \%$ & $91 \%$ & $88 \%$ & $91 \%$ & $91 \%$ & $92 \%$ & $92 \%$ & $92 \%$ & $93 \%$ & $78 \%$ \\
\hline & $\mathrm{PP}$ & $0 \%$ & $0 \%$ & $0 \%$ & $0 \%$ & $0 \%$ & $0 \%$ & $0 \%$ & $0 \%$ & $0 \%$ & $0 \%$ & $0 \%$ & $0 \%$ & $0 \%$ & $0 \%$ & $0 \%$ & $0 \%$ & $0 \%$ & $0 \%$ & $0 \%$ & $0 \%$ \\
\hline & AFP & $0 \%$ & $0 \%$ & $0 \%$ & $0 \%$ & $0 \%$ & $0 \%$ & $0 \%$ & $0 \%$ & $0 \%$ & $0 \%$ & $0 \%$ & $0 \%$ & $0 \%$ & $0 \%$ & $0 \%$ & $0 \%$ & $0 \%$ & $0 \%$ & $0 \%$ & $14 \%$ \\
\hline & TRCS & $1 \%$ & $1 \%$ & $1 \%$ & $1 \%$ & $1 \%$ & $1 \%$ & $1 \%$ & $1 \%$ & $1 \%$ & $1 \%$ & $1 \%$ & $1 \%$ & $1 \%$ & $1 \%$ & $1 \%$ & $1 \%$ & $1 \%$ & $1 \%$ & $1 \%$ & $1 \%$ \\
\hline & WM\&C & $0 \%$ & $1 \%$ & $1 \%$ & $1 \%$ & $2 \%$ & $1 \%$ & $1 \%$ & $1 \%$ & $1 \%$ & $1 \%$ & $1 \%$ & $2 \%$ & $5 \%$ & $2 \%$ & $2 \%$ & $1 \%$ & $1 \%$ & $1 \%$ & $1 \%$ & $1 \%$ \\
\hline & Total $\left[\mathrm{kgP}-\right.$ eq $\left.^{-1}{ }^{-1}\right]$ & -0.24 & -0.17 & -0.24 & -0.23 & -0.15 & -0.14 & -0.17 & -0.18 & -0.22 & -0.14 & -0.14 & -0.11 & -0.05 & -0.12 & \begin{tabular}{|c|}
-0.11 \\
\end{tabular} & -0.18 & -0.16 & -0.21 & -0.24 & -0.18 \\
\hline \multirow{7}{*}{ 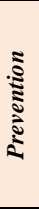 } & LUC & $4 \%$ & $5 \%$ & $4 \%$ & $4 \%$ & $4 \%$ & $4 \%$ & $4 \%$ & $4 \%$ & $4 \%$ & $4 \%$ & $4 \%$ & $4 \%$ & $4 \%$ & $4 \%$ & $5 \%$ & $5 \%$ & $4 \%$ & $4 \%$ & $4 \%$ & $5 \%$ \\
\hline & FP & $94 \%$ & $94 \%$ & $94 \%$ & $94 \%$ & $94 \%$ & $94 \%$ & $94 \%$ & $94 \%$ & $94 \%$ & $94 \%$ & $94 \%$ & $94 \%$ & $94 \%$ & $94 \%$ & $93 \%$ & $94 \%$ & $94 \%$ & $94 \%$ & $94 \%$ & $93 \%$ \\
\hline & PP & $1 \%$ & $1 \%$ & $1 \%$ & $1 \%$ & $1 \%$ & $1 \%$ & $1 \%$ & $1 \%$ & $1 \%$ & $1 \%$ & $1 \%$ & $1 \%$ & $0 \%$ & $1 \%$ & $1 \%$ & $0 \%$ & $1 \%$ & $1 \%$ & $1 \%$ & $1 \%$ \\
\hline & AFP & $0 \%$ & $0 \%$ & $0 \%$ & $0 \%$ & $0 \%$ & $0 \%$ & $0 \%$ & $0 \%$ & $0 \%$ & $0 \%$ & $0 \%$ & $0 \%$ & $0 \%$ & $0 \%$ & $0 \%$ & $0 \%$ & $0 \%$ & $0 \%$ & $0 \%$ & $0 \%$ \\
\hline & TRCS & $1 \%$ & $1 \%$ & $1 \%$ & $1 \%$ & $1 \%$ & $1 \%$ & $1 \%$ & $1 \%$ & $1 \%$ & $1 \%$ & $1 \%$ & $1 \%$ & $1 \%$ & $1 \%$ & $1 \%$ & $1 \%$ & $1 \%$ & $1 \%$ & $1 \%$ & $1 \%$ \\
\hline & WM\&C & $0 \%$ & $0 \%$ & $0 \%$ & $0 \%$ & $0 \%$ & $0 \%$ & $0 \%$ & $0 \%$ & $0 \%$ & $0 \%$ & $0 \%$ & $0 \%$ & $0 \%$ & $0 \%$ & $0 \%$ & $0 \%$ & $0 \%$ & $0 \%$ & $0 \%$ & $0 \%$ \\
\hline & Total $\left[\mathrm{kgP}_{\text {-eq }} \mathrm{t}^{-1}\right]$ & -0.31 & -0.29 & -0.30 & -0.35 & -0.38 & -0.28 & -0.27 & -0.27 & -0.36 & -0.26 & -0.29 & -0.34 & -0.24 & -0.31 & -0.28 & -0.26 & -0.29 & -0.35 & -0.41 & -0.31 \\
\hline \multirow{5}{*}{ 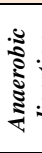 } & LUC & $0 \%$ & $0 \%$ & $0 \%$ & $0 \%$ & $0 \%$ & $0 \%$ & $0 \%$ & $0 \%$ & $0 \%$ & $0 \%$ & $0 \%$ & $0 \%$ & $0 \%$ & $0 \%$ & $0 \%$ & $0 \%$ & $0 \%$ & $0 \%$ & $0 \%$ & $0 \%$ \\
\hline & FP & $0 \%$ & $0 \%$ & $0 \%$ & $0 \%$ & $0 \%$ & $0 \%$ & $0 \%$ & $0 \%$ & $0 \%$ & $0 \%$ & $0 \%$ & $0 \%$ & $0 \%$ & $0 \%$ & $0 \%$ & $0 \%$ & $0 \%$ & $0 \%$ & $0 \%$ & $0 \%$ \\
\hline & PP & $0 \%$ & $0 \%$ & $0 \%$ & $0 \%$ & $0 \%$ & $0 \%$ & $0 \%$ & $0 \%$ & $0 \%$ & $0 \%$ & $0 \%$ & $0 \%$ & $0 \%$ & $0 \%$ & $0 \%$ & $0 \%$ & $0 \%$ & $0 \%$ & $0 \%$ & $0 \%$ \\
\hline & AFP & $0 \%$ & $0 \%$ & $0 \%$ & $0 \%$ & $0 \%$ & $0 \%$ & $0 \%$ & $0 \%$ & $0 \%$ & $0 \%$ & $0 \%$ & $0 \%$ & $0 \%$ & $0 \%$ & $0 \%$ & $0 \%$ & $0 \%$ & $0 \%$ & $0 \%$ & $0 \%$ \\
\hline & TRCS & $0 \%$ & $0 \%$ & $0 \%$ & $0 \%$ & $0 \%$ & $0 \%$ & $0 \%$ & $0 \%$ & $0 \%$ & $0 \%$ & $0 \%$ & $0 \%$ & $0 \%$ & $0 \%$ & $0 \%$ & $0 \%$ & $0 \%$ & $0 \%$ & $0 \%$ & $0 \%$ \\
\hline
\end{tabular}




\begin{tabular}{|c|c|c|c|c|c|c|c|c|c|c|c|c|c|c|c|c|c|c|c|c|c|}
\hline & WM\&C & $100 \%$ & $100 \%$ & $100 \%$ & $100 \%$ & $100 \%$ & $100 \%$ & $100 \%$ & $100 \%$ & $100 \%$ & $100 \%$ & $100 \%$ & $100 \%$ & $100 \%$ & $100 \%$ & $100 \%$ & $100 \%$ & $100 \%$ & $100 \%$ & $100 \%$ & $100 \%$ \\
\hline & Total $\left[\mathrm{kgP}_{\text {-eq }} \mathrm{t}^{-1}\right]$ & $\begin{array}{r}3.2 \mathrm{E}- \\
03\end{array}$ & $\begin{array}{r}3.1 \mathrm{E}- \\
03\end{array}$ & $\begin{array}{r}\text { 3.1E- } \\
03\end{array}$ & $\begin{array}{r}3.7 \mathrm{E}- \\
03\end{array}$ & $\begin{array}{r}3.8 \mathrm{E}- \\
03\end{array}$ & $\begin{array}{r}2.9 \mathrm{E}- \\
03\end{array}$ & $\begin{array}{r}2.9 \mathrm{E}- \\
03\end{array}$ & $\begin{array}{r}2.9 \mathrm{E}- \\
03\end{array}$ & $\begin{array}{r}3.5 \mathrm{E}- \\
03\end{array}$ & $\begin{array}{r}2.5 \mathrm{E}- \\
03\end{array}$ & $\begin{array}{r}3.1 \mathrm{E}- \\
03\end{array}$ & $\begin{array}{r}3.6 \mathrm{E}- \\
03\end{array}$ & $\begin{array}{r}2.8 \mathrm{E}- \\
03\end{array}$ & $\begin{array}{r}3.3 \mathrm{E}- \\
03\end{array}$ & $\begin{array}{r}\text { 3.0E- } \\
03\end{array}$ & $\begin{array}{r}2.8 \mathrm{E}- \\
03\end{array}$ & $\begin{array}{r}3.0 \mathrm{E}- \\
03\end{array}$ & $\begin{array}{r}3.6 \mathrm{E}- \\
03\end{array}$ & $\begin{array}{r}\text { 3.6E- } \\
03\end{array}$ & $\begin{array}{r}2.6 \mathrm{E}- \\
03\end{array}$ \\
\hline \multirow{7}{*}{ 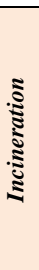 } & LUC & $0 \%$ & $0 \%$ & $0 \%$ & $0 \%$ & $0 \%$ & $0 \%$ & $0 \%$ & $0 \%$ & $0 \%$ & $0 \%$ & $0 \%$ & $0 \%$ & $0 \%$ & $0 \%$ & $0 \%$ & $0 \%$ & $0 \%$ & $0 \%$ & $0 \%$ & $0 \%$ \\
\hline & FP & $0 \%$ & $0 \%$ & $0 \%$ & $0 \%$ & $0 \%$ & $0 \%$ & $0 \%$ & $0 \%$ & $0 \%$ & $0 \%$ & $0 \%$ & $0 \%$ & $0 \%$ & $0 \%$ & $0 \%$ & $0 \%$ & $0 \%$ & $0 \%$ & $0 \%$ & $0 \%$ \\
\hline & PP & $0 \%$ & $0 \%$ & $0 \%$ & $0 \%$ & $0 \%$ & $0 \%$ & $0 \%$ & $0 \%$ & $0 \%$ & $0 \%$ & $0 \%$ & $0 \%$ & $0 \%$ & $0 \%$ & $0 \%$ & $0 \%$ & $0 \%$ & $0 \%$ & $0 \%$ & $0 \%$ \\
\hline & AFP & $0 \%$ & $0 \%$ & $0 \%$ & $0 \%$ & $0 \%$ & $0 \%$ & $0 \%$ & $0 \%$ & $0 \%$ & $0 \%$ & $0 \%$ & $0 \%$ & $0 \%$ & $0 \%$ & $0 \%$ & $0 \%$ & $0 \%$ & $0 \%$ & $0 \%$ & $0 \%$ \\
\hline & TRCS & $0 \%$ & $0 \%$ & $0 \%$ & $0 \%$ & $0 \%$ & $0 \%$ & $0 \%$ & $0 \%$ & $0 \%$ & $0 \%$ & $0 \%$ & $0 \%$ & $0 \%$ & $0 \%$ & $0 \%$ & $0 \%$ & $0 \%$ & $0 \%$ & $0 \%$ & $0 \%$ \\
\hline & WM\&C & $100 \%$ & $100 \%$ & $100 \%$ & $100 \%$ & $100 \%$ & $100 \%$ & $100 \%$ & $100 \%$ & $100 \%$ & $100 \%$ & $100 \%$ & $100 \%$ & $100 \%$ & $100 \%$ & $100 \%$ & $100 \%$ & $100 \%$ & $100 \%$ & $100 \%$ & $100 \%$ \\
\hline & Total $\left[\mathrm{kgP}_{\text {-eq }} \mathrm{t}^{-1}\right]$ & $\begin{array}{r}2.5 \mathrm{E}- \\
03 \\
\end{array}$ & $\begin{array}{r}2.9 \mathrm{E}- \\
03 \\
\end{array}$ & $\begin{array}{r}2.4 \mathrm{E}- \\
03 \\
\end{array}$ & $\begin{array}{r}3.0 \mathrm{E}- \\
03 \\
\end{array}$ & $\begin{array}{r}2.9 \mathrm{E}- \\
03 \\
\end{array}$ & $\begin{array}{r}2.3 \mathrm{E}- \\
03 \\
\end{array}$ & $\begin{array}{r}2.2 \mathrm{E}- \\
03 \\
\end{array}$ & $\begin{array}{r}2.2 \mathrm{E}- \\
03 \\
\end{array}$ & $\begin{array}{r}2.7 \mathrm{E}- \\
03 \\
\end{array}$ & $\begin{array}{r}1.8 \mathrm{E}- \\
03 \\
\end{array}$ & $\begin{array}{r}2.3 \mathrm{E}- \\
03 \\
\end{array}$ & $\begin{array}{r}2.6 \mathrm{E}- \\
03 \\
\end{array}$ & $\begin{array}{r}2.2 \mathrm{E}- \\
03 \\
\end{array}$ & $\begin{array}{r}2.4 \mathrm{E}- \\
03 \\
\end{array}$ & $\begin{array}{r}2.3 \mathrm{E}- \\
03 \\
\end{array}$ & $\begin{array}{r}2.1 \mathrm{E}- \\
03 \\
\end{array}$ & $\begin{array}{r}2.2 \mathrm{E}- \\
03 \\
\end{array}$ & $\begin{array}{r}2.6 \mathrm{E}- \\
03 \\
\end{array}$ & $\begin{array}{r}2.7 \mathrm{E}- \\
03 \\
\end{array}$ & $\begin{array}{r}2.0 \mathrm{E}- \\
03 \\
\end{array}$ \\
\hline & Ecotoxicity & & & & & & & & & & & & & & & & & & & & \\
\hline \multirow{7}{*}{ 气 } & LUC & $3 \%$ & $2 \%$ & $2 \%$ & $3 \%$ & $3 \%$ & $3 \%$ & $3 \%$ & $3 \%$ & $3 \%$ & $2 \%$ & $3 \%$ & $3 \%$ & $2 \%$ & $3 \%$ & $3 \%$ & $2 \%$ & $3 \%$ & $3 \%$ & $3 \%$ & $3 \%$ \\
\hline & FP & $93 \%$ & $93 \%$ & $94 \%$ & $92 \%$ & $90 \%$ & $92 \%$ & $91 \%$ & $93 \%$ & $92 \%$ & $91 \%$ & $91 \%$ & $88 \%$ & $85 \%$ & $90 \%$ & $90 \%$ & $94 \%$ & $92 \%$ & $91 \%$ & $91 \%$ & $65 \%$ \\
\hline & PP & $0 \%$ & $0 \%$ & $0 \%$ & $0 \%$ & $0 \%$ & $0 \%$ & $1 \%$ & $0 \%$ & $0 \%$ & $0 \%$ & $0 \%$ & $0 \%$ & $0 \%$ & $0 \%$ & $0 \%$ & $0 \%$ & $0 \%$ & $0 \%$ & $0 \%$ & $0 \%$ \\
\hline & AFP & $0 \%$ & $0 \%$ & $0 \%$ & $0 \%$ & $0 \%$ & $0 \%$ & $0 \%$ & $0 \%$ & $0 \%$ & $0 \%$ & $0 \%$ & $0 \%$ & $0 \%$ & $0 \%$ & $0 \%$ & $0 \%$ & $0 \%$ & $0 \%$ & $0 \%$ & $27 \%$ \\
\hline & TRCS & $2 \%$ & $2 \%$ & $2 \%$ & $2 \%$ & $2 \%$ & $2 \%$ & $3 \%$ & $2 \%$ & $2 \%$ & $3 \%$ & $2 \%$ & $2 \%$ & $2 \%$ & $2 \%$ & $2 \%$ & $2 \%$ & $3 \%$ & $2 \%$ & $3 \%$ & $2 \%$ \\
\hline & WM\&C & $1 \%$ & $2 \%$ & $2 \%$ & $2 \%$ & $4 \%$ & $3 \%$ & $3 \%$ & $2 \%$ & $2 \%$ & $3 \%$ & $4 \%$ & $7 \%$ & $10 \%$ & $5 \%$ & $5 \%$ & $1 \%$ & $3 \%$ & $3 \%$ & $2 \%$ & $2 \%$ \\
\hline & Total $\left[\right.$ CTU U $\left.\mathrm{t}^{-1}\right]$ & -3200 & -2700 & -3200 & -2900 & -1800 & -2200 & -2100 & -2700 & -2600 & -2000 & -2000 & -1500 & -900 & -1700 & -1700 & -3000 & -2300 & -2500 & -2600 & -2300 \\
\hline \multirow{7}{*}{ 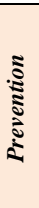 } & LUC & $4 \%$ & $4 \%$ & $4 \%$ & $6 \%$ & $3 \%$ & $4 \%$ & $7 \%$ & $4 \%$ & $4 \%$ & $3 \%$ & $4 \%$ & $4 \%$ & $5 \%$ & $4 \%$ & $4 \%$ & $4 \%$ & $4 \%$ & $3 \%$ & $3 \%$ & $3 \%$ \\
\hline & FP & $89 \%$ & $91 \%$ & $89 \%$ & $83 \%$ & $92 \%$ & $88 \%$ & $76 \%$ & $89 \%$ & $90 \%$ & $90 \%$ & $90 \%$ & $89 \%$ & $86 \%$ & $89 \%$ & $91 \%$ & $90 \%$ & $90 \%$ & $91 \%$ & $92 \%$ & $93 \%$ \\
\hline & $\mathrm{PP}$ & $1 \%$ & $1 \%$ & $1 \%$ & $2 \%$ & $1 \%$ & $1 \%$ & $3 \%$ & $1 \%$ & $1 \%$ & $1 \%$ & $1 \%$ & $1 \%$ & $1 \%$ & $1 \%$ & $1 \%$ & $1 \%$ & $1 \%$ & $1 \%$ & $1 \%$ & $1 \%$ \\
\hline & AFP & $0 \%$ & $0 \%$ & $0 \%$ & $0 \%$ & $0 \%$ & $0 \%$ & $0 \%$ & $0 \%$ & $0 \%$ & $0 \%$ & $0 \%$ & $0 \%$ & $0 \%$ & $0 \%$ & $0 \%$ & $0 \%$ & $0 \%$ & $0 \%$ & $0 \%$ & $0 \%$ \\
\hline & TRCS & $6 \%$ & $5 \%$ & $6 \%$ & $8 \%$ & $4 \%$ & $6 \%$ & $14 \%$ & $6 \%$ & $5 \%$ & $6 \%$ & $6 \%$ & $5 \%$ & $8 \%$ & $6 \%$ & $5 \%$ & $5 \%$ & $5 \%$ & $5 \%$ & $4 \%$ & $4 \%$ \\
\hline & WM\&C & $0 \%$ & $0 \%$ & $0 \%$ & $0 \%$ & $0 \%$ & $0 \%$ & $0 \%$ & $0 \%$ & $0 \%$ & $0 \%$ & $0 \%$ & $0 \%$ & $0 \%$ & $0 \%$ & $0 \%$ & $0 \%$ & $0 \%$ & $0 \%$ & $0 \%$ & $0 \%$ \\
\hline & Total $\left[\mathrm{CTU}_{\mathrm{e}} \mathrm{t}^{-1}\right]$ & -2200 & -2400 & -2200 & -1400 & -3300 & -1900 & -1000 & -2200 & -2700 & -2300 & -2300 & -2300 & -1400 & -2200 & -2500 & -2100 & -2400 & -2900 & -3700 & -3700 \\
\hline \multirow{7}{*}{ 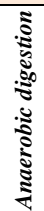 } & LUC & $0 \%$ & $0 \%$ & $0 \%$ & $0 \%$ & $0 \%$ & $0 \%$ & $0 \%$ & $0 \%$ & $0 \%$ & $0 \%$ & $0 \%$ & $0 \%$ & $0 \%$ & $0 \%$ & $0 \%$ & $0 \%$ & $0 \%$ & $0 \%$ & $0 \%$ & $0 \%$ \\
\hline & FP & $0 \%$ & $0 \%$ & $0 \%$ & $0 \%$ & $0 \%$ & $0 \%$ & $0 \%$ & $0 \%$ & $0 \%$ & $0 \%$ & $0 \%$ & $0 \%$ & $0 \%$ & $0 \%$ & $0 \%$ & $0 \%$ & $0 \%$ & $0 \%$ & $0 \%$ & $0 \%$ \\
\hline & PP & $0 \%$ & $0 \%$ & $0 \%$ & $0 \%$ & $0 \%$ & $0 \%$ & $0 \%$ & $0 \%$ & $0 \%$ & $0 \%$ & $0 \%$ & $0 \%$ & $0 \%$ & $0 \%$ & $0 \%$ & $0 \%$ & $0 \%$ & $0 \%$ & $0 \%$ & $0 \%$ \\
\hline & AFP & $0 \%$ & $0 \%$ & $0 \%$ & $0 \%$ & $0 \%$ & $0 \%$ & $0 \%$ & $0 \%$ & $0 \%$ & $0 \%$ & $0 \%$ & $0 \%$ & $0 \%$ & $0 \%$ & $0 \%$ & $0 \%$ & $0 \%$ & $0 \%$ & $0 \%$ & $0 \%$ \\
\hline & TRCS & $0 \%$ & $0 \%$ & $0 \%$ & $0 \%$ & $0 \%$ & $0 \%$ & $0 \%$ & $0 \%$ & $0 \%$ & $0 \%$ & $0 \%$ & $0 \%$ & $0 \%$ & $0 \%$ & $0 \%$ & $0 \%$ & $0 \%$ & $0 \%$ & $0 \%$ & $0 \%$ \\
\hline & WM\&C & $100 \%$ & $100 \%$ & $100 \%$ & $100 \%$ & $100 \%$ & $100 \%$ & $100 \%$ & $100 \%$ & $100 \%$ & $100 \%$ & $100 \%$ & $100 \%$ & $100 \%$ & $100 \%$ & $100 \%$ & $100 \%$ & $100 \%$ & $100 \%$ & $100 \%$ & $100 \%$ \\
\hline & Total $\left[\mathbf{C T U}_{\mathrm{e}} \mathrm{t}^{-1}\right]$ & -120 & -120 & -120 & -140 & -120 & -110 & -140 & -110 & -120 & -100 & -120 & -140 & -110 & -130 & -110 & -110 & -120 & -130 & -120 & -90 \\
\hline \multirow{7}{*}{ 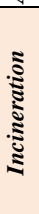 } & LUC & $0 \%$ & $0 \%$ & $0 \%$ & $0 \%$ & $0 \%$ & $0 \%$ & $0 \%$ & $0 \%$ & $0 \%$ & $0 \%$ & $0 \%$ & $0 \%$ & $0 \%$ & $0 \%$ & $0 \%$ & $0 \%$ & $0 \%$ & $0 \%$ & $0 \%$ & $0 \%$ \\
\hline & FP & $0 \%$ & $0 \%$ & $0 \%$ & $0 \%$ & $-1 \%$ & $0 \%$ & $0 \%$ & $0 \%$ & $0 \%$ & $0 \%$ & $0 \%$ & $0 \%$ & $0 \%$ & $0 \%$ & $0 \%$ & $0 \%$ & $0 \%$ & $0 \%$ & $0 \%$ & $0 \%$ \\
\hline & $\mathrm{PP}$ & $0 \%$ & $0 \%$ & $0 \%$ & $0 \%$ & $0 \%$ & $0 \%$ & $0 \%$ & $0 \%$ & $0 \%$ & $0 \%$ & $0 \%$ & $0 \%$ & $0 \%$ & $0 \%$ & $0 \%$ & $0 \%$ & $0 \%$ & $0 \%$ & $0 \%$ & $0 \%$ \\
\hline & AFP & $0 \%$ & $0 \%$ & $0 \%$ & $0 \%$ & $0 \%$ & $0 \%$ & $0 \%$ & $0 \%$ & $0 \%$ & $0 \%$ & $0 \%$ & $0 \%$ & $0 \%$ & $0 \%$ & $0 \%$ & $0 \%$ & $0 \%$ & $0 \%$ & $0 \%$ & $0 \%$ \\
\hline & TRCS & $-2 \%$ & $-2 \%$ & $-2 \%$ & $-1 \%$ & $-2 \%$ & $-2 \%$ & $-2 \%$ & $-2 \%$ & $-2 \%$ & $-2 \%$ & $-2 \%$ & $-2 \%$ & $-2 \%$ & $-2 \%$ & $-2 \%$ & $-2 \%$ & $-2 \%$ & $-2 \%$ & $-2 \%$ & $-2 \%$ \\
\hline & WM\&C & $102 \%$ & $102 \%$ & $102 \%$ & $101 \%$ & $103 \%$ & $102 \%$ & $102 \%$ & $102 \%$ & $102 \%$ & $102 \%$ & $102 \%$ & $102 \%$ & $102 \%$ & $102 \%$ & $102 \%$ & $102 \%$ & $102 \%$ & $102 \%$ & $102 \%$ & $102 \%$ \\
\hline & Total $\left[\mathrm{CTU}_{\mathrm{e}} \mathrm{t}^{-1}\right]$ & -65 & -76 & -63 & -79 & -76 & -60 & -58 & -57 & -71 & -47 & -62 & -70 & -58 & -64 & -59 & -55 & -57 & -70 & -70 & -53 \\
\hline \multicolumn{2}{|c|}{ Human Toxicity, cancer } & & & & & & & & & & & & & & & & & & & & \\
\hline & LUC & $3.3 \%$ & $3.2 \%$ & $2.8 \%$ & $3.2 \%$ & $2.5 \%$ & $2.9 \%$ & $2.7 \%$ & $3.1 \%$ & $2.9 \%$ & $2.4 \%$ & $2.6 \%$ & $2.1 \%$ & $1.6 \%$ & $2.3 \%$ & $2.4 \%$ & $3.4 \%$ & $2.8 \%$ & $2.8 \%$ & $2.8 \%$ & $3.9 \%$ \\
\hline \multirow{6}{*}{ 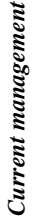 } & FP & 82.2 & 73.4 & 80.8 & 76.9 & 62.7 & 69.6 & 76.3 & 76.8 & 76.7 & 73.1 & 66.9 & 55.0 & 34.8 & 59.9 & 58.2 & 77.3 & 71.3 & 73.2 & 77.9 & 74.0 \\
\hline & $\mathrm{FP}$ & $\%$ & $\%$ & $\%$ & $\%$ & $\%$ & $\%$ & $\%$ & $\%$ & $\%$ & $\%$ & $\%$ & $\%$ & $\%$ & $\%$ & $\%$ & $\%$ & $\%$ & $\%$ & $\%$ & $\%$ \\
\hline & PP & $0.4 \%$ & $0.3 \%$ & $0.3 \%$ & $0.3 \%$ & $0.3 \%$ & $0.3 \%$ & $0.6 \%$ & $0.4 \%$ & $0.4 \%$ & $0.4 \%$ & $0.3 \%$ & $0.3 \%$ & $0.2 \%$ & $0.3 \%$ & $0.2 \%$ & $0.3 \%$ & $0.4 \%$ & $0.3 \%$ & $0.4 \%$ & $0.4 \%$ \\
\hline & AFP & $0.0 \%$ & $0.0 \%$ & $0.0 \%$ & $0.0 \%$ & $0.0 \%$ & $0.0 \%$ & $0.0 \%$ & $0.0 \%$ & $0.0 \%$ & $0.0 \%$ & $0.0 \%$ & $0.0 \%$ & $0.0 \%$ & $0.0 \%$ & $0.0 \%$ & $0.0 \%$ & $0.0 \%$ & $0.0 \%$ & $0.0 \%$ & $2.8 \%$ \\
\hline & TRCS & $1.1 \%$ & $1.3 \%$ & $1.0 \%$ & $1.0 \%$ & $0.7 \%$ & $1.1 \%$ & $1.0 \%$ & $1.2 \%$ & $0.9 \%$ & $1.1 \%$ & $0.9 \%$ & $0.7 \%$ & $0.7 \%$ & $0.8 \%$ & $0.9 \%$ & $1.4 \%$ & $1.0 \%$ & $0.9 \%$ & $0.8 \%$ & $0.9 \%$ \\
\hline & WM\&C & 13.0 & 21.8 & 15.2 & 18.6 & 33.8 & 26.1 & $\begin{array}{l}19.4 \\
\end{array}$ & 18.6 & 19.1 & 23.0 & 29.3 & 42.0 & 62.8 & 36.6 & 38.2 & 17.6 & 24.6 & 22.8 & 18.1 & 18.0 \\
\hline
\end{tabular}




\begin{tabular}{|c|c|c|c|c|c|c|c|c|c|c|c|c|c|c|c|c|c|c|c|c|c|}
\hline & Total $\left[\mathrm{CTU}_{\mathrm{h}} \mathrm{t}^{-1}\right]$ & $\begin{array}{r}4.4 \mathrm{E}- \\
05 \\
\end{array}$ & $\begin{array}{r}3.2 \mathrm{E}- \\
05 \\
\end{array}$ & $\begin{array}{r}4.5 \mathrm{E}- \\
05 \\
\end{array}$ & $\begin{array}{r}4.4 \mathrm{E}- \\
05 \\
\end{array}$ & $\begin{array}{r}3.7 \mathrm{E}- \\
05 \\
\end{array}$ & $\begin{array}{r}3.0 \mathrm{E}- \\
05 \\
\end{array}$ & $\begin{array}{r}3.7 \mathrm{E}- \\
05 \\
\end{array}$ & $\begin{array}{r}3.6 \mathrm{E}- \\
05 \\
\end{array}$ & $\begin{array}{r}4.4 \mathrm{E}- \\
05 \\
\end{array}$ & $\begin{array}{r}3.2 \mathrm{E}- \\
05\end{array}$ & $\begin{array}{r}3.3 \mathrm{E}- \\
05\end{array}$ & $\begin{array}{r}3.2 \mathrm{E}- \\
05\end{array}$ & $\begin{array}{r}1.9 \mathrm{E}- \\
05\end{array}$ & $\begin{array}{r}3.1 \mathrm{E}- \\
05\end{array}$ & $\begin{array}{r}2.8 \mathrm{E}- \\
05\end{array}$ & $\begin{array}{r}3.4 \mathrm{E}- \\
05\end{array}$ & $\begin{array}{r}3.5 \mathrm{E}- \\
05\end{array}$ & $\begin{array}{r}4.3 \mathrm{E}- \\
05\end{array}$ & $\begin{array}{r}4.8 \mathrm{E}- \\
05\end{array}$ & $\begin{array}{r}3.3 \mathrm{E}- \\
05\end{array}$ \\
\hline \multirow{7}{*}{ 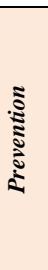 } & LUC & $2 \%$ & $3 \%$ & $2 \%$ & $2 \%$ & $2 \%$ & $2 \%$ & $1 \%$ & $2 \%$ & $2 \%$ & $2 \%$ & $2 \%$ & $2 \%$ & $2 \%$ & $2 \%$ & $3 \%$ & $2 \%$ & $2 \%$ & $2 \%$ & $2 \%$ & $2 \%$ \\
\hline & FP & $96 \%$ & $95 \%$ & $96 \%$ & $96 \%$ & $96 \%$ & $96 \%$ & $97 \%$ & $96 \%$ & $96 \%$ & $96 \%$ & $96 \%$ & $96 \%$ & $96 \%$ & $96 \%$ & $95 \%$ & $96 \%$ & $96 \%$ & $96 \%$ & $96 \%$ & $96 \%$ \\
\hline & PP & $1 \%$ & $1 \%$ & $1 \%$ & $1 \%$ & $1 \%$ & $1 \%$ & $1 \%$ & $1 \%$ & $1 \%$ & $1 \%$ & $1 \%$ & $1 \%$ & $1 \%$ & $1 \%$ & $1 \%$ & $1 \%$ & $1 \%$ & $1 \%$ & $1 \%$ & $1 \%$ \\
\hline & AFP & $0 \%$ & $0 \%$ & $0 \%$ & $0 \%$ & $0 \%$ & $0 \%$ & $0 \%$ & $0 \%$ & $0 \%$ & $0 \%$ & $0 \%$ & $0 \%$ & $0 \%$ & $0 \%$ & $0 \%$ & $0 \%$ & $0 \%$ & $0 \%$ & $0 \%$ & $0 \%$ \\
\hline & TRCS & $1 \%$ & $1 \%$ & $1 \%$ & $1 \%$ & $1 \%$ & $1 \%$ & $1 \%$ & $1 \%$ & $1 \%$ & $1 \%$ & $1 \%$ & $1 \%$ & $1 \%$ & $1 \%$ & $1 \%$ & $1 \%$ & $1 \%$ & $1 \%$ & $1 \%$ & $1 \%$ \\
\hline & WM\&C & $0 \%$ & $0 \%$ & $0 \%$ & $0 \%$ & $0 \%$ & $0 \%$ & $0 \%$ & $0 \%$ & $0 \%$ & $0 \%$ & $0 \%$ & $0 \%$ & $0 \%$ & $0 \%$ & $0 \%$ & $0 \%$ & $0 \%$ & $0 \%$ & $0 \%$ & $0 \%$ \\
\hline & Total [CTUt $\left.{ }^{-1}\right]$ & $\begin{array}{r}5.9 \mathrm{E}- \\
05\end{array}$ & $5.5 \mathrm{E}-$ & $\begin{array}{r}-- \\
6.3 \mathrm{E}- \\
05\end{array}$ & $\begin{array}{r}6.8 \mathrm{E}- \\
05\end{array}$ & $\begin{array}{r}7.7 \mathrm{E}- \\
05\end{array}$ & $\begin{array}{r}5.9 \mathrm{E}- \\
05\end{array}$ & $\begin{array}{c}- \\
7.9 \mathrm{E}-\end{array}$ & $\begin{array}{r}6.1 \mathrm{E}- \\
05\end{array}$ & $\begin{array}{r}7.8 \mathrm{E}- \\
05\end{array}$ & $\begin{array}{r}6.0 \mathrm{E}- \\
05\end{array}$ & $\begin{array}{r}6.2 \mathrm{E}- \\
05\end{array}$ & $\begin{array}{r}6.7 \mathrm{E}- \\
05\end{array}$ & $\begin{array}{r}- \\
5.1 \mathrm{E}-\end{array}$ & $\begin{array}{r}6.7 \mathrm{E}- \\
05\end{array}$ & $5.5 \mathrm{E}-$ & $\begin{array}{r}5.4 \mathrm{E}- \\
05\end{array}$ & $\begin{array}{r}6.2 \mathrm{E}- \\
05\end{array}$ & $\begin{array}{r}6.9 \mathrm{E}- \\
05\end{array}$ & $\begin{array}{r}9.3 \mathrm{E}- \\
05\end{array}$ & $\begin{array}{r}7.2 \mathrm{E}- \\
05\end{array}$ \\
\hline \multirow{7}{*}{ 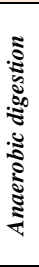 } & LUC & $0 \%$ & $0 \%$ & $0 \%$ & $0 \%$ & $0 \%$ & $0 \%$ & $0 \%$ & $0 \%$ & $0 \%$ & $0 \%$ & $0 \%$ & $0 \%$ & $0 \%$ & $0 \%$ & $0 \%$ & $0 \%$ & $0 \%$ & $0 \%$ & $0 \%$ & $0 \%$ \\
\hline & FP & $0 \%$ & $0 \%$ & $0 \%$ & $0 \%$ & $0 \%$ & $0 \%$ & $0 \%$ & $0 \%$ & $0 \%$ & $0 \%$ & $0 \%$ & $0 \%$ & $0 \%$ & $0 \%$ & $0 \%$ & $0 \%$ & $0 \%$ & $0 \%$ & $0 \%$ & $0 \%$ \\
\hline & $\mathrm{PP}$ & $0 \%$ & $0 \%$ & $0 \%$ & $0 \%$ & $0 \%$ & $0 \%$ & $0 \%$ & $0 \%$ & $0 \%$ & $0 \%$ & $0 \%$ & $0 \%$ & $0 \%$ & $0 \%$ & $0 \%$ & $0 \%$ & $0 \%$ & $0 \%$ & $0 \%$ & $0 \%$ \\
\hline & AFP & $0 \%$ & $0 \%$ & $0 \%$ & $0 \%$ & $0 \%$ & $0 \%$ & $0 \%$ & $0 \%$ & $0 \%$ & $0 \%$ & $0 \%$ & $0 \%$ & $0 \%$ & $0 \%$ & $0 \%$ & $0 \%$ & $0 \%$ & $0 \%$ & $0 \%$ & $0 \%$ \\
\hline & TRCS & $0 \%$ & $0 \%$ & $0 \%$ & $0 \%$ & $0 \%$ & $0 \%$ & $0 \%$ & $0 \%$ & $0 \%$ & $0 \%$ & $0 \%$ & $0 \%$ & $0 \%$ & $0 \%$ & $0 \%$ & $0 \%$ & $0 \%$ & $0 \%$ & $0 \%$ & $0 \%$ \\
\hline & WM\&C & $100 \%$ & $100 \%$ & $100 \%$ & $100 \%$ & $100 \%$ & $100 \%$ & $100 \%$ & $100 \%$ & $100 \%$ & $100 \%$ & $100 \%$ & $100 \%$ & $100 \%$ & $100 \%$ & $100 \%$ & $100 \%$ & $100 \%$ & $100 \%$ & $100 \%$ & $100 \%$ \\
\hline & Total $\left[\mathrm{CTU}_{\mathrm{ht}} \mathrm{t}^{-1}\right]$ & $\begin{array}{r}1.6 \mathrm{E}- \\
05 \\
\end{array}$ & $\begin{array}{r}1.6 \mathrm{E}- \\
05 \\
\end{array}$ & $\begin{array}{r}1.6 \mathrm{E}- \\
05 \\
\end{array}$ & $\begin{array}{r}1.8 \mathrm{E}- \\
05\end{array}$ & $\begin{array}{r}1.8 \mathrm{E}- \\
05\end{array}$ & $\begin{array}{r}1.5 \mathrm{E}- \\
05\end{array}$ & $\begin{array}{r}1.7 \mathrm{E}- \\
05\end{array}$ & $\begin{array}{r}1.5 \mathrm{E}- \\
05\end{array}$ & $\begin{array}{r}1.8 \mathrm{E}- \\
05\end{array}$ & $\begin{array}{r}1.4 \mathrm{E}- \\
05\end{array}$ & $\begin{array}{r}1.6 \mathrm{E}- \\
05\end{array}$ & $\begin{array}{r}1.9 \mathrm{E}- \\
05\end{array}$ & $\begin{array}{r}1.4 \mathrm{E}- \\
05\end{array}$ & $\begin{array}{r}1.8 \mathrm{E}- \\
05\end{array}$ & $\begin{array}{r}1.6 \mathrm{E}- \\
05\end{array}$ & $\begin{array}{r}1.5 \mathrm{E}- \\
05\end{array}$ & $\begin{array}{r}1.6 \mathrm{E}- \\
05\end{array}$ & $\begin{array}{r}1.9 \mathrm{E}- \\
05\end{array}$ & $\begin{array}{r}1.8 \mathrm{E}- \\
05\end{array}$ & $\begin{array}{r}1.4 \mathrm{E}- \\
05\end{array}$ \\
\hline \multirow{7}{*}{ 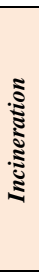 } & LUC & $0 \%$ & $0 \%$ & $0 \%$ & $0 \%$ & $0 \%$ & $0 \%$ & $0 \%$ & $0 \%$ & $0 \%$ & $0 \%$ & $0 \%$ & $0 \%$ & $0 \%$ & $0 \%$ & $0 \%$ & $0 \%$ & $0 \%$ & $0 \%$ & $0 \%$ & $0 \%$ \\
\hline & FP & $0 \%$ & $0 \%$ & $0 \%$ & $0 \%$ & $-1 \%$ & $0 \%$ & $0 \%$ & $0 \%$ & $0 \%$ & $0 \%$ & $0 \%$ & $0 \%$ & $0 \%$ & $0 \%$ & $0 \%$ & $0 \%$ & $0 \%$ & $0 \%$ & $0 \%$ & $0 \%$ \\
\hline & PP & $0 \%$ & $0 \%$ & $0 \%$ & $0 \%$ & $0 \%$ & $0 \%$ & $0 \%$ & $0 \%$ & $0 \%$ & $0 \%$ & $0 \%$ & $0 \%$ & $0 \%$ & $0 \%$ & $0 \%$ & $0 \%$ & $0 \%$ & $0 \%$ & $0 \%$ & $0 \%$ \\
\hline & AFP & $0 \%$ & $0 \%$ & $0 \%$ & $0 \%$ & $0 \%$ & $0 \%$ & $0 \%$ & $0 \%$ & $0 \%$ & $0 \%$ & $0 \%$ & $0 \%$ & $0 \%$ & $0 \%$ & $0 \%$ & $0 \%$ & $0 \%$ & $0 \%$ & $0 \%$ & $0 \%$ \\
\hline & TRCS & $0 \%$ & $0 \%$ & $0 \%$ & $0 \%$ & $0 \%$ & $0 \%$ & $0 \%$ & $0 \%$ & $0 \%$ & $-1 \%$ & $0 \%$ & $0 \%$ & $0 \%$ & $0 \%$ & $0 \%$ & $0 \%$ & $0 \%$ & $0 \%$ & $0 \%$ & $-1 \%$ \\
\hline & WM\&C & $0 \%$ & $0 \%$ & $0 \%$ & $0 \%$ & $0 \%$ & $0 \%$ & $0 \%$ & $0 \%$ & $0 \%$ & $0 \%$ & $0 \%$ & $0 \%$ & $0 \%$ & $0 \%$ & $0 \%$ & $0 \%$ & $0 \%$ & $0 \%$ & $0 \%$ & $0 \%$ \\
\hline & Total $\left[\mathrm{CTU}_{\mathrm{h}} \mathbf{t}^{-1}\right]$ & $\begin{array}{r}- \\
9.9 \mathrm{E}- \\
07 \\
\end{array}$ & $\begin{array}{r}-2 \mathrm{E}- \\
06 \\
\end{array}$ & $\begin{array}{r}- \\
9.6 \mathrm{E}- \\
07 \\
\end{array}$ & $\begin{array}{r}1.2 \mathrm{E}- \\
06 \\
\end{array}$ & $\begin{array}{r}1.2 \mathrm{E}- \\
06 \\
\end{array}$ & $\begin{array}{r}- \\
9.3 \mathrm{E}- \\
07 \\
\end{array}$ & $\begin{array}{r}8.9 \mathrm{E}- \\
07 \\
\end{array}$ & $\begin{array}{r}8.8 \mathrm{E}- \\
07 \\
\end{array}$ & $\begin{array}{r}1.1 \mathrm{E}- \\
06 \\
\end{array}$ & $\begin{array}{r}- \\
7.4 \mathrm{E}- \\
07 \\
\end{array}$ & $\begin{array}{r}9.5 \mathrm{E}- \\
07 \\
\end{array}$ & $\begin{array}{r}1.1 \mathrm{E}- \\
06 \\
\end{array}$ & $\begin{array}{r}- \\
9.0 \mathrm{E}- \\
07 \\
\end{array}$ & $\begin{array}{r}9.8 \mathrm{E}- \\
07 \\
\end{array}$ & $\begin{array}{r}- \\
9.2 \mathrm{E}- \\
07 \\
\end{array}$ & $\begin{array}{r}- \\
8.6 \mathrm{E}- \\
07 \\
\end{array}$ & $\begin{array}{r}8.8 \mathrm{E}- \\
07 \\
\end{array}$ & $\begin{array}{r}- \\
1.1 \mathrm{E}- \\
06\end{array}$ & $\begin{array}{r}- \\
1.1 \mathrm{E}- \\
06\end{array}$ & $\begin{array}{r}8.2 \mathrm{E}- \\
07 \\
\end{array}$ \\
\hline \multicolumn{22}{|c|}{ Fossil Resource } \\
\hline \multirow{7}{*}{ 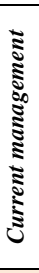 } & LUC & $11 \%$ & $12 \%$ & $10 \%$ & $11 \%$ & $9 \%$ & $10 \%$ & $8 \%$ & $10 \%$ & $10 \%$ & $7 \%$ & $9 \%$ & $8 \%$ & $7 \%$ & $9 \%$ & $10 \%$ & $12 \%$ & $9 \%$ & $9 \%$ & $9 \%$ & $12 \%$ \\
\hline & FP & $72 \%$ & $63 \%$ & $73 \%$ & $67 \%$ & $61 \%$ & $63 \%$ & $71 \%$ & $69 \%$ & $71 \%$ & $72 \%$ & $65 \%$ & $58 \%$ & $35 \%$ & $61 \%$ & $57 \%$ & $65 \%$ & $67 \%$ & $69 \%$ & $74 \%$ & $63 \%$ \\
\hline & PP & $4 \%$ & $3 \%$ & $4 \%$ & $4 \%$ & $3 \%$ & $4 \%$ & $7 \%$ & $4 \%$ & $4 \%$ & $4 \%$ & $4 \%$ & $3 \%$ & $3 \%$ & $4 \%$ & $3 \%$ & $4 \%$ & $4 \%$ & $4 \%$ & $4 \%$ & $3 \%$ \\
\hline & AFP & $0 \%$ & $0 \%$ & $0 \%$ & $0 \%$ & $0 \%$ & $0 \%$ & $0 \%$ & $0 \%$ & $0 \%$ & $0 \%$ & $0 \%$ & $0 \%$ & $0 \%$ & $0 \%$ & $0 \%$ & $0 \%$ & $0 \%$ & $0 \%$ & $0 \%$ & $9 \%$ \\
\hline & TRCS & $6 \%$ & $7 \%$ & $5 \%$ & $5 \%$ & $4 \%$ & $6 \%$ & $5 \%$ & $6 \%$ & $5 \%$ & $6 \%$ & $5 \%$ & $4 \%$ & $4 \%$ & $5 \%$ & $5 \%$ & $8 \%$ & $6 \%$ & $5 \%$ & $4 \%$ & $4 \%$ \\
\hline & WM\&C & $8 \%$ & $15 \%$ & $9 \%$ & $12 \%$ & $22 \%$ & $17 \%$ & $9 \%$ & $10 \%$ & $11 \%$ & $10 \%$ & $17 \%$ & $26 \%$ & $50 \%$ & $22 \%$ & $25 \%$ & $11 \%$ & $13 \%$ & $13 \%$ & $9 \%$ & $9 \%$ \\
\hline & Total $\left[\mathrm{MJt}^{-1}\right]$ & $\begin{array}{r}-- \\
1.2 \mathrm{E}+ \\
04\end{array}$ & $\begin{array}{r}-- \\
8.0 \mathrm{E}+ \\
03\end{array}$ & $\begin{array}{r}1.2 \mathrm{E}+ \\
04\end{array}$ & $\begin{array}{r}1.2 \mathrm{E}+ \\
04\end{array}$ & $\begin{array}{r}9.1 \mathrm{E}+ \\
03 \\
\end{array}$ & $\begin{array}{r}7.9 \mathrm{E}+ \\
03 \\
\end{array}$ & $\begin{array}{r}1.1 \mathrm{E}+ \\
04\end{array}$ & $\begin{array}{r}1.0 \mathrm{E}+ \\
04\end{array}$ & $\begin{array}{r}1.2 \mathrm{E}+ \\
04\end{array}$ & $\begin{array}{r}1.0 \mathrm{E}+ \\
04 \\
\end{array}$ & $\begin{array}{r}8.8 \mathrm{E}+ \\
03\end{array}$ & $\begin{array}{r}7.8 E+ \\
03 \\
\end{array}$ & $\begin{array}{r}3.9 \mathrm{E}+ \\
03 \\
\end{array}$ & $\begin{array}{r}7.9 \mathrm{E}+ \\
03 \\
\end{array}$ & $\begin{array}{r}6.6 \mathrm{E}+ \\
03 \\
\end{array}$ & $\begin{array}{r}-- \\
8.7 \mathrm{E}+ \\
03\end{array}$ & $\begin{array}{r}9.6 \mathrm{E}+ \\
03 \\
\end{array}$ & $\begin{array}{r}- \\
1.2 \mathrm{E}+ \\
04\end{array}$ & $\begin{array}{r}1.4 \mathrm{E}+ \\
04\end{array}$ & $\begin{array}{r}9.9 \mathrm{E}+ \\
03\end{array}$ \\
\hline \multirow{7}{*}{ 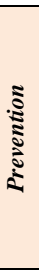 } & LUC & $6 \%$ & $7 \%$ & $6 \%$ & $6 \%$ & $6 \%$ & $6 \%$ & $4 \%$ & $5 \%$ & $5 \%$ & $4 \%$ & $5 \%$ & $6 \%$ & $6 \%$ & $5 \%$ & $7 \%$ & $6 \%$ & $6 \%$ & $6 \%$ & $5 \%$ & $6 \%$ \\
\hline & FP & $82 \%$ & $82 \%$ & $83 \%$ & $83 \%$ & $82 \%$ & $83 \%$ & $85 \%$ & $83 \%$ & $83 \%$ & $84 \%$ & $83 \%$ & $84 \%$ & $82 \%$ & $84 \%$ & $81 \%$ & $81 \%$ & $83 \%$ & $83 \%$ & $84 \%$ & $84 \%$ \\
\hline & $\begin{array}{l}\mathrm{PP} \\
\end{array}$ & $7 \%$ & $5 \%$ & $6 \%$ & $6 \%$ & $7 \%$ & $6 \%$ & $6 \%$ & $6 \%$ & $6 \%$ & $6 \%$ & $6 \%$ & $6 \%$ & $6 \%$ & $6 \%$ & $6 \%$ & $6 \%$ & $6 \%$ & $7 \%$ & $6 \%$ & $4 \%$ \\
\hline & AFP & $0 \%$ & $0 \%$ & $0 \%$ & $0 \%$ & $0 \%$ & $0 \%$ & $0 \%$ & $0 \%$ & $0 \%$ & $0 \%$ & $0 \%$ & $0 \%$ & $0 \%$ & $0 \%$ & $0 \%$ & $0 \%$ & $0 \%$ & $0 \%$ & $0 \%$ & $0 \%$ \\
\hline & TRCS & $6 \%$ & $6 \%$ & $5 \%$ & $5 \%$ & $5 \%$ & $6 \%$ & $5 \%$ & $6 \%$ & $5 \%$ & $6 \%$ & $5 \%$ & $5 \%$ & $6 \%$ & $5 \%$ & $6 \%$ & $6 \%$ & $6 \%$ & $5 \%$ & $4 \%$ & $5 \%$ \\
\hline & WM\&C & $0 \%$ & $0 \%$ & $0 \%$ & $0 \%$ & $0 \%$ & $0 \%$ & $0 \%$ & $0 \%$ & $0 \%$ & $0 \%$ & $0 \%$ & $0 \%$ & $0 \%$ & $0 \%$ & $0 \%$ & $0 \%$ & $0 \%$ & $0 \%$ & $0 \%$ & $0 \%$ \\
\hline & Total $\left[\mathrm{MJt}^{-1}\right]$ & $\begin{array}{r}- \\
2.1 \mathrm{E}+ \\
04\end{array}$ & $\begin{array}{r}1.95 \mathrm{E} \\
+04\end{array}$ & $\begin{array}{r}- \\
2.2 \mathrm{E}+ \\
04\end{array}$ & $\begin{array}{r}2.4 \mathrm{E}+ \\
04\end{array}$ & $\begin{array}{r}2.5 \mathrm{E}+ \\
04\end{array}$ & $\begin{array}{r}- \\
2.1 \mathrm{E}+ \\
04\end{array}$ & $\begin{array}{r}2.8 \mathrm{E}+ \\
04\end{array}$ & $\begin{array}{r}2.2 \mathrm{E}+ \\
04\end{array}$ & $\begin{array}{r}2.7 \mathrm{E}+ \\
04\end{array}$ & $\begin{array}{r}2.3 \mathrm{E}+ \\
04\end{array}$ & $\begin{array}{r}2.3 \mathrm{E}+ \\
04\end{array}$ & $\begin{array}{r}2.5 \mathrm{E}+ \\
04\end{array}$ & $\begin{array}{r}- \\
1.8 \mathrm{E}+ \\
04\end{array}$ & $\begin{array}{r}2.5 \mathrm{E}+ \\
04\end{array}$ & $\begin{array}{r}1.98 \mathrm{E} \\
+04\end{array}$ & $\begin{array}{r}1.9 \mathrm{E}+ \\
04\end{array}$ & $\begin{array}{r}2.3 \mathrm{E}+ \\
04\end{array}$ & $\begin{array}{r}2.6 \mathrm{E}+ \\
04\end{array}$ & $\begin{array}{r}- \\
3.0 \mathrm{E}+ \\
04\end{array}$ & $\begin{array}{r}2.4 \mathrm{E}+ \\
04\end{array}$ \\
\hline \multirow{5}{*}{ : } & LUC & $0 \%$ & $0 \%$ & $0 \%$ & $0 \%$ & $0 \%$ & $0 \%$ & $0 \%$ & $0 \%$ & $0 \%$ & $0 \%$ & $0 \%$ & $0 \%$ & $0 \%$ & $0 \%$ & $0 \%$ & $0 \%$ & $0 \%$ & $0 \%$ & $0 \%$ & $0 \%$ \\
\hline & FP & $0 \%$ & $0 \%$ & $0 \%$ & $0 \%$ & $0 \%$ & $0 \%$ & $0 \%$ & $0 \%$ & $0 \%$ & $0 \%$ & $0 \%$ & $0 \%$ & $0 \%$ & $0 \%$ & $0 \%$ & $0 \%$ & $0 \%$ & $0 \%$ & $0 \%$ & $0 \%$ \\
\hline & $\mathrm{PP}$ & $0 \%$ & $0 \%$ & $0 \%$ & $0 \%$ & $0 \%$ & $0 \%$ & $0 \%$ & $0 \%$ & $0 \%$ & $0 \%$ & $0 \%$ & $0 \%$ & $0 \%$ & $0 \%$ & $0 \%$ & $0 \%$ & $0 \%$ & $0 \%$ & $0 \%$ & $0 \%$ \\
\hline & AFP & $0 \%$ & $0 \%$ & $0 \%$ & $0 \%$ & $0 \%$ & $0 \%$ & $0 \%$ & $0 \%$ & $0 \%$ & $0 \%$ & $0 \%$ & $0 \%$ & $0 \%$ & $0 \%$ & $0 \%$ & $0 \%$ & $0 \%$ & $0 \%$ & $0 \%$ & $0 \%$ \\
\hline & TRCS & $0 \%$ & $0 \%$ & $0 \%$ & $0 \%$ & $0 \%$ & $0 \%$ & $0 \%$ & $0 \%$ & $0 \%$ & $0 \%$ & $0 \%$ & $0 \%$ & $0 \%$ & $0 \%$ & $0 \%$ & $0 \%$ & $0 \%$ & $0 \%$ & $0 \%$ & $0 \%$ \\
\hline
\end{tabular}




\begin{tabular}{|c|c|c|c|c|c|c|c|c|c|c|c|c|c|c|c|c|c|c|c|c|c|}
\hline & WM\&C & $100 \%$ & $100 \%$ & $100 \%$ & $100 \%$ & $100 \%$ & $100 \%$ & $100 \%$ & $100 \%$ & $100 \%$ & $100 \%$ & $100 \%$ & $100 \%$ & $100 \%$ & $100 \%$ & $100 \%$ & $100 \%$ & $100 \%$ & $100 \%$ & $100 \%$ & $100 \%$ \\
\hline & Total $\left[\mathbf{M J t}^{-1}\right]$ & $\begin{array}{r}- \\
2.6 \mathrm{E}+ \\
03\end{array}$ & $\begin{array}{r}- \\
2.7 \mathrm{E}+ \\
03\end{array}$ & $\begin{array}{r}- \\
2.6 \mathrm{E}+ \\
03\end{array}$ & $\begin{array}{r}3.1 \mathrm{E}+ \\
03\end{array}$ & $\begin{array}{r}3.0 \mathrm{E}+ \\
03\end{array}$ & $\begin{array}{r}2.5 \mathrm{E}+ \\
03\end{array}$ & $\begin{array}{r}2.4 \mathrm{E}+ \\
03\end{array}$ & $\begin{array}{r}- \\
2.4 \mathrm{E}+ \\
03\end{array}$ & $\begin{array}{r}- \\
2.8 \mathrm{E}+ \\
03\end{array}$ & $\begin{array}{r}- \\
2.0 \mathrm{E}+ \\
03\end{array}$ & $\begin{array}{r}2.6 \mathrm{E}+ \\
03\end{array}$ & $\begin{array}{r}- \\
2.9 \mathrm{E}+ \\
03\end{array}$ & $\begin{array}{r}- \\
2.4 \mathrm{E}+ \\
03\end{array}$ & $\begin{array}{r}- \\
2.7 \mathrm{E}+ \\
03\end{array}$ & $\begin{array}{r}- \\
2.5 \mathrm{E}+ \\
03\end{array}$ & $\begin{array}{r}2.3 \mathrm{E}+ \\
03\end{array}$ & $\begin{array}{r}2.4 \mathrm{E}+ \\
03\end{array}$ & $\begin{array}{r}- \\
2.9 \mathrm{E}+ \\
03\end{array}$ & $\begin{array}{r}- \\
2.8 \mathrm{E}+ \\
03\end{array}$ & $\begin{array}{r}- \\
2.0 \mathrm{E}+ \\
03\end{array}$ \\
\hline \multirow{7}{*}{ 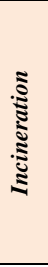 } & LUC & $0 \%$ & $0 \%$ & $0 \%$ & $0 \%$ & $0 \%$ & $0 \%$ & $0 \%$ & $0 \%$ & $0 \%$ & $0 \%$ & $0 \%$ & $0 \%$ & $0 \%$ & $0 \%$ & $0 \%$ & $0 \%$ & $0 \%$ & $0 \%$ & $0 \%$ & $0 \%$ \\
\hline & FP & $0 \%$ & $0 \%$ & $0 \%$ & $0 \%$ & $0 \%$ & $0 \%$ & $0 \%$ & $0 \%$ & $0 \%$ & $0 \%$ & $0 \%$ & $0 \%$ & $0 \%$ & $0 \%$ & $0 \%$ & $0 \%$ & $0 \%$ & $0 \%$ & $0 \%$ & $0 \%$ \\
\hline & PP & $0 \%$ & $0 \%$ & $0 \%$ & $0 \%$ & $0 \%$ & $0 \%$ & $0 \%$ & $0 \%$ & $0 \%$ & $0 \%$ & $0 \%$ & $0 \%$ & $0 \%$ & $0 \%$ & $0 \%$ & $0 \%$ & $0 \%$ & $0 \%$ & $0 \%$ & $0 \%$ \\
\hline & AFP & $0 \%$ & $0 \%$ & $0 \%$ & $0 \%$ & $0 \%$ & $0 \%$ & $0 \%$ & $0 \%$ & $0 \%$ & $0 \%$ & $0 \%$ & $0 \%$ & $0 \%$ & $0 \%$ & $0 \%$ & $0 \%$ & $0 \%$ & $0 \%$ & $0 \%$ & $0 \%$ \\
\hline & TRCS & $-1 \%$ & $-1 \%$ & $-1 \%$ & $-1 \%$ & $-1 \%$ & $-1 \%$ & $-1 \%$ & $-1 \%$ & $-1 \%$ & $-2 \%$ & $-1 \%$ & $-1 \%$ & $-1 \%$ & $-1 \%$ & $-1 \%$ & $-1 \%$ & $-1 \%$ & $-1 \%$ & $-1 \%$ & $-2 \%$ \\
\hline & WM\&C & $101 \%$ & $101 \%$ & $101 \%$ & $101 \%$ & $101 \%$ & $101 \%$ & $101 \%$ & $101 \%$ & $101 \%$ & $102 \%$ & $101 \%$ & $101 \%$ & $101 \%$ & $101 \%$ & $101 \%$ & $101 \%$ & $101 \%$ & $101 \%$ & $101 \%$ & $102 \%$ \\
\hline & Total $\left[\mathbf{M J t}^{-1}\right]$ & $\begin{array}{r}- \\
3.1 \mathrm{E}+ \\
03 \\
\end{array}$ & $\begin{array}{r}- \\
3.6 \mathrm{E}+ \\
03 \\
\end{array}$ & $\begin{array}{r}3.0 \mathrm{E}+ \\
03 \\
\end{array}$ & $\begin{array}{r}3.8 \mathrm{E}+ \\
03 \\
\end{array}$ & $\begin{array}{r}- \\
3.7 \mathrm{E}+ \\
03 \\
\end{array}$ & $\begin{array}{r}2.8 \mathrm{E}+ \\
03 \\
\end{array}$ & $\begin{array}{r}- \\
2.7 \mathrm{E}+ \\
03 \\
\end{array}$ & $\begin{array}{r}2.7 \mathrm{E}+ \\
03 \\
\end{array}$ & $\begin{array}{r}- \\
3.4 \mathrm{E}+ \\
03 \\
\end{array}$ & $\begin{array}{r}- \\
2.2 \mathrm{E}+ \\
03 \\
\end{array}$ & $\begin{array}{r}2.9 \mathrm{E}+ \\
03 \\
\end{array}$ & $\begin{array}{r}3.3 \mathrm{E}+ \\
03 \\
\end{array}$ & $\begin{array}{r}- \\
2.7 \mathrm{E}+ \\
03 \\
\end{array}$ & $\begin{array}{r}3.0 \mathrm{E}+ \\
03 \\
\end{array}$ & $\begin{array}{r}- \\
2.8 \mathrm{E}+ \\
03 \\
\end{array}$ & $\begin{array}{r}2.6 \mathrm{E}+ \\
03 \\
\end{array}$ & $\begin{array}{r}2.7 \mathrm{E}+ \\
03 \\
\end{array}$ & $\begin{array}{r}- \\
3.3 \mathrm{E}+ \\
03 \\
\end{array}$ & $\begin{array}{r}- \\
3.4 \mathrm{E}+ \\
03 \\
\end{array}$ & $\begin{array}{r}2.5 \mathrm{E}+ \\
03 \\
\end{array}$ \\
\hline \multicolumn{2}{|r|}{ Water Depletion } & & & & & & & & & & & & & & & & & & & & \\
\hline \multirow{7}{*}{ 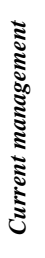 } & LUC & $-2 \%$ & $-1 \%$ & $-2 \%$ & $-2 \%$ & $-1 \%$ & $-1 \%$ & $-3 \%$ & $-2 \%$ & $-2 \%$ & $-2 \%$ & $-1 \%$ & $-1 \%$ & $0 \%$ & $-1 \%$ & $-1 \%$ & $-2 \%$ & $-2 \%$ & $-2 \%$ & $-2 \%$ & $-3 \%$ \\
\hline & FP & $61 \%$ & $55 \%$ & $58 \%$ & $54 \%$ & $33 \%$ & $42 \%$ & $25 \%$ & $51 \%$ & $46 \%$ & $28 \%$ & $35 \%$ & $24 \%$ & $16 \%$ & $29 \%$ & $32 \%$ & $58 \%$ & $41 \%$ & $42 \%$ & $43 \%$ & $49 \%$ \\
\hline & PP & $0 \%$ & $0 \%$ & $0 \%$ & $0 \%$ & $0 \%$ & $0 \%$ & $0 \%$ & $0 \%$ & $0 \%$ & $0 \%$ & $0 \%$ & $0 \%$ & $0 \%$ & $0 \%$ & $0 \%$ & $0 \%$ & $0 \%$ & $0 \%$ & $0 \%$ & $0 \%$ \\
\hline & AFP & $0 \%$ & $0 \%$ & $0 \%$ & $0 \%$ & $0 \%$ & $0 \%$ & $0 \%$ & $0 \%$ & $0 \%$ & $0 \%$ & $0 \%$ & $0 \%$ & $0 \%$ & $0 \%$ & $0 \%$ & $0 \%$ & $0 \%$ & $0 \%$ & $0 \%$ & $-3 \%$ \\
\hline & TRCS & $6 \%$ & $6 \%$ & $5 \%$ & $4 \%$ & $3 \%$ & $5 \%$ & $6 \%$ & $6 \%$ & $5 \%$ & $4 \%$ & $4 \%$ & $3 \%$ & $2 \%$ & $3 \%$ & $3 \%$ & $6 \%$ & $5 \%$ & $4 \%$ & $5 \%$ & $6 \%$ \\
\hline & WM\&C & $34 \%$ & $41 \%$ & $38 \%$ & $44 \%$ & $65 \%$ & $55 \%$ & $72 \%$ & $46 \%$ & $51 \%$ & $71 \%$ & $62 \%$ & $75 \%$ & $82 \%$ & $69 \%$ & $65 \%$ & $37 \%$ & $56 \%$ & $55 \%$ & $55 \%$ & $51 \%$ \\
\hline & Total $\left[\mathrm{kg}_{\text {water }} \mathrm{t}^{-1}\right]$ & $\begin{array}{r}2.2 \mathrm{E}+ \\
03 \\
\end{array}$ & $\begin{array}{r}2.2 \mathrm{E}+ \\
03 \\
\end{array}$ & $\begin{array}{r}2.3 \mathrm{E}+ \\
03 \\
\end{array}$ & $\begin{array}{r}2.4 \mathrm{E}+ \\
03 \\
\end{array}$ & $\begin{array}{r}2.4 \mathrm{E}+ \\
03 \\
\end{array}$ & $\begin{array}{r}2.0 \mathrm{E}+ \\
03 \\
\end{array}$ & $\begin{array}{r}1.1 \mathrm{E}+ \\
03 \\
\end{array}$ & $\begin{array}{r}1.8 \mathrm{E}+ \\
03 \\
\end{array}$ & $\begin{array}{r}2.1 \mathrm{E}+ \\
03 \\
\end{array}$ & $\begin{array}{r}1.2 \mathrm{E}+ \\
03 \\
\end{array}$ & $\begin{array}{r}2.0 \mathrm{E}+ \\
03 \\
\end{array}$ & $\begin{array}{r}2.2 \mathrm{E}+ \\
03 \\
\end{array}$ & $\begin{array}{r}2.0 \mathrm{E}+ \\
03 \\
\end{array}$ & $\begin{array}{r}2.0 \mathrm{E}+ \\
03 \\
\end{array}$ & $\begin{array}{r}2.1 \mathrm{E}+ \\
03 \\
\end{array}$ & $\begin{array}{r}2.1 \mathrm{E}+ \\
03 \\
\end{array}$ & $\begin{array}{r}1.8 \mathrm{E}+ \\
03 \\
\end{array}$ & $\begin{array}{r}2.2 \mathrm{E}+ \\
03 \\
\end{array}$ & $\begin{array}{r}1.9 \mathrm{E}+ \\
03 \\
\end{array}$ & $\begin{array}{r}1.3 \mathrm{E}+ \\
03 \\
\end{array}$ \\
\hline \multirow{7}{*}{ 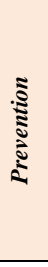 } & LUC & $-2 \%$ & $-3 \%$ & $-2 \%$ & $-2 \%$ & $-2 \%$ & $-2 \%$ & $-2 \%$ & $-2 \%$ & $-1 \%$ & $-1 \%$ & $-2 \%$ & $-2 \%$ & $-2 \%$ & $-2 \%$ & $-2 \%$ & $-2 \%$ & $-2 \%$ & $-2 \%$ & $-1 \%$ & $-1 \%$ \\
\hline & FP & $95 \%$ & $95 \%$ & $96 \%$ & $94 \%$ & $97 \%$ & $95 \%$ & $95 \%$ & $95 \%$ & $97 \%$ & $96 \%$ & $96 \%$ & $97 \%$ & $94 \%$ & $96 \%$ & $96 \%$ & $95 \%$ & $96 \%$ & $97 \%$ & $98 \%$ & $97 \%$ \\
\hline & PP & $0 \%$ & $0 \%$ & $0 \%$ & $0 \%$ & $0 \%$ & $0 \%$ & $0 \%$ & $0 \%$ & $0 \%$ & $0 \%$ & $0 \%$ & $0 \%$ & $0 \%$ & $0 \%$ & $0 \%$ & $0 \%$ & $0 \%$ & $0 \%$ & $0 \%$ & $0 \%$ \\
\hline & AFP & $0 \%$ & $0 \%$ & $0 \%$ & $0 \%$ & $0 \%$ & $0 \%$ & $0 \%$ & $0 \%$ & $0 \%$ & $0 \%$ & $0 \%$ & $0 \%$ & $0 \%$ & $0 \%$ & $0 \%$ & $0 \%$ & $0 \%$ & $0 \%$ & $0 \%$ & $0 \%$ \\
\hline & TRCS & $7 \%$ & $8 \%$ & $6 \%$ & $7 \%$ & $4 \%$ & $7 \%$ & $7 \%$ & $6 \%$ & $4 \%$ & $5 \%$ & $5 \%$ & $5 \%$ & $9 \%$ & $5 \%$ & $6 \%$ & $7 \%$ & $6 \%$ & $4 \%$ & $3 \%$ & $5 \%$ \\
\hline & WM\&C & $0 \%$ & $0 \%$ & $0 \%$ & $0 \%$ & $0 \%$ & $0 \%$ & $0 \%$ & $0 \%$ & $0 \%$ & $0 \%$ & $0 \%$ & $0 \%$ & $-1 \%$ & $0 \%$ & $0 \%$ & $0 \%$ & $0 \%$ & $0 \%$ & $0 \%$ & $0 \%$ \\
\hline & Total $\left[\mathrm{kg}_{\text {water }} \mathrm{t}^{-1}\right]$ & $\begin{array}{r}2.4 \mathrm{E}+ \\
03 \\
\end{array}$ & $\begin{array}{r}1.9 \mathrm{E}+ \\
03 \\
\end{array}$ & $\begin{array}{r}2.6 \mathrm{E}+ \\
03 \\
\end{array}$ & $\begin{array}{r}2.4 \mathrm{E}+ \\
03 \\
\end{array}$ & $\begin{array}{r}3.5 \mathrm{E}+ \\
03 \\
\end{array}$ & $\begin{array}{r}2.3 \mathrm{E}+ \\
03 \\
\end{array}$ & $\begin{array}{r}2.3 \mathrm{E}+ \\
03 \\
\end{array}$ & $\begin{array}{r}2.4 \mathrm{E}+ \\
03 \\
\end{array}$ & $\begin{array}{r}3.4 \mathrm{E}+ \\
03 \\
\end{array}$ & $\begin{array}{r}2.7 \mathrm{E}+ \\
03 \\
\end{array}$ & $\begin{array}{r}2.6 \mathrm{E}+ \\
03 \\
\end{array}$ & $\begin{array}{r}2.5 \mathrm{E}+ \\
03 \\
\end{array}$ & $\begin{array}{r}1.5 \mathrm{E}+ \\
03 \\
\end{array}$ & $\begin{array}{r}2.4 \mathrm{E}+ \\
03 \\
\end{array}$ & $\begin{array}{r}2.4 \mathrm{E}+ \\
03 \\
\end{array}$ & $\begin{array}{r}2.1 \mathrm{E}+ \\
03 \\
\end{array}$ & $\begin{array}{r}2.5 \mathrm{E}+ \\
03 \\
\end{array}$ & $\begin{array}{r}3.2 \mathrm{E}+ \\
03 \\
\end{array}$ & $\begin{array}{r}4.1 \mathrm{E}+ \\
03 \\
\end{array}$ & $\begin{array}{r}3.6 \mathrm{E}+ \\
03\end{array}$ \\
\hline \multirow{7}{*}{ 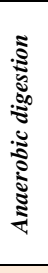 } & LUC & $0 \%$ & $0 \%$ & $0 \%$ & $0 \%$ & $0 \%$ & $0 \%$ & $0 \%$ & $0 \%$ & $0 \%$ & $0 \%$ & $0 \%$ & $0 \%$ & $0 \%$ & $0 \%$ & $0 \%$ & $0 \%$ & $0 \%$ & $0 \%$ & $0 \%$ & $0 \%$ \\
\hline & FP & $0 \%$ & $0 \%$ & $0 \%$ & $0 \%$ & $0 \%$ & $0 \%$ & $0 \%$ & $0 \%$ & $0 \%$ & $0 \%$ & $0 \%$ & $0 \%$ & $0 \%$ & $0 \%$ & $0 \%$ & $0 \%$ & $0 \%$ & $0 \%$ & $0 \%$ & $0 \%$ \\
\hline & PP & $0 \%$ & $0 \%$ & $0 \%$ & $0 \%$ & $0 \%$ & $0 \%$ & $0 \%$ & $0 \%$ & $0 \%$ & $0 \%$ & $0 \%$ & $0 \%$ & $0 \%$ & $0 \%$ & $0 \%$ & $0 \%$ & $0 \%$ & $0 \%$ & $0 \%$ & $0 \%$ \\
\hline & AFP & $0 \%$ & $0 \%$ & $0 \%$ & $0 \%$ & $0 \%$ & $0 \%$ & $0 \%$ & $0 \%$ & $0 \%$ & $0 \%$ & $0 \%$ & $0 \%$ & $0 \%$ & $0 \%$ & $0 \%$ & $0 \%$ & $0 \%$ & $0 \%$ & $0 \%$ & $0 \%$ \\
\hline & TRCS & $0 \%$ & $0 \%$ & $0 \%$ & $0 \%$ & $0 \%$ & $0 \%$ & $0 \%$ & $0 \%$ & $0 \%$ & $0 \%$ & $0 \%$ & $0 \%$ & $0 \%$ & $0 \%$ & $0 \%$ & $0 \%$ & $0 \%$ & $0 \%$ & $0 \%$ & $0 \%$ \\
\hline & WM\&C & $100 \%$ & $100 \%$ & $100 \%$ & $100 \%$ & $100 \%$ & $100 \%$ & $100 \%$ & $100 \%$ & $100 \%$ & $100 \%$ & $100 \%$ & $100 \%$ & $100 \%$ & $100 \%$ & $100 \%$ & $100 \%$ & $100 \%$ & $100 \%$ & $100 \%$ & $100 \%$ \\
\hline & Total $\left[\mathrm{kg}_{\text {water }} \mathrm{t}^{-1}\right]$ & $\begin{array}{r}2.1 \mathrm{E}+ \\
03\end{array}$ & $\begin{array}{r}2.0 \mathrm{E}+ \\
03\end{array}$ & $\begin{array}{r}2.1 \mathrm{E}+ \\
03\end{array}$ & $\begin{array}{r}2.4 \mathrm{E}+ \\
03\end{array}$ & $\begin{array}{r}2.4 \mathrm{E}+ \\
03\end{array}$ & $\begin{array}{r}2.0 \mathrm{E}+ \\
03\end{array}$ & $\begin{array}{r}1.9 \mathrm{E}+ \\
03\end{array}$ & $\begin{array}{r}1.9 \mathrm{E}+ \\
03\end{array}$ & $\begin{array}{r}2.2 \mathrm{E}+ \\
03\end{array}$ & $\begin{array}{r}1.6 \mathrm{E}+ \\
03\end{array}$ & $\begin{array}{r}2.1 \mathrm{E}+ \\
03\end{array}$ & $\begin{array}{r}2.3 \mathrm{E}+ \\
03\end{array}$ & $\begin{array}{r}2.0 \mathrm{E}+ \\
03\end{array}$ & $\begin{array}{r}2.2 \mathrm{E}+ \\
03\end{array}$ & $\begin{array}{r}2.0 \mathrm{E}+ \\
03\end{array}$ & $\begin{array}{r}1.9 \mathrm{E}+ \\
03\end{array}$ & $\begin{array}{r}1.9 \mathrm{E}+ \\
03\end{array}$ & $\begin{array}{r}2.3 \mathrm{E}+ \\
03\end{array}$ & $\begin{array}{r}2.1 \mathrm{E}+ \\
03\end{array}$ & $\begin{array}{r}1.6 \mathrm{E}+ \\
03\end{array}$ \\
\hline \multirow{7}{*}{ 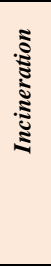 } & LUC & $0 \%$ & $0 \%$ & $0 \%$ & $0 \%$ & $0 \%$ & $0 \%$ & $0 \%$ & $0 \%$ & $0 \%$ & $0 \%$ & $0 \%$ & $0 \%$ & $0 \%$ & $0 \%$ & $0 \%$ & $0 \%$ & $0 \%$ & $0 \%$ & $0 \%$ & $0 \%$ \\
\hline & FP & $0 \%$ & $0 \%$ & $0 \%$ & $0 \%$ & $0 \%$ & $0 \%$ & $0 \%$ & $0 \%$ & $0 \%$ & $0 \%$ & $0 \%$ & $0 \%$ & $0 \%$ & $0 \%$ & $0 \%$ & $0 \%$ & $0 \%$ & $0 \%$ & $0 \%$ & $0 \%$ \\
\hline & PP & $0 \%$ & $0 \%$ & $0 \%$ & $0 \%$ & $0 \%$ & $0 \%$ & $0 \%$ & $0 \%$ & $0 \%$ & $0 \%$ & $0 \%$ & $0 \%$ & $0 \%$ & $0 \%$ & $0 \%$ & $0 \%$ & $0 \%$ & $0 \%$ & $0 \%$ & $0 \%$ \\
\hline & AFP & $0 \%$ & $0 \%$ & $0 \%$ & $0 \%$ & $0 \%$ & $0 \%$ & $0 \%$ & $0 \%$ & $0 \%$ & $0 \%$ & $0 \%$ & $0 \%$ & $0 \%$ & $0 \%$ & $0 \%$ & $0 \%$ & $0 \%$ & $0 \%$ & $0 \%$ & $0 \%$ \\
\hline & TRCS & $0 \%$ & $0 \%$ & $0 \%$ & $0 \%$ & $0 \%$ & $0 \%$ & $0 \%$ & $0 \%$ & $0 \%$ & $0 \%$ & $0 \%$ & $0 \%$ & $0 \%$ & $0 \%$ & $0 \%$ & $0 \%$ & $0 \%$ & $0 \%$ & $0 \%$ & $0 \%$ \\
\hline & WM\&C & $100 \%$ & $100 \%$ & $100 \%$ & $100 \%$ & $100 \%$ & $100 \%$ & $100 \%$ & $100 \%$ & $100 \%$ & $100 \%$ & $100 \%$ & $100 \%$ & $100 \%$ & $100 \%$ & $100 \%$ & $100 \%$ & $100 \%$ & $100 \%$ & $100 \%$ & $100 \%$ \\
\hline & Total $\left[\mathrm{kg}_{\text {water }} \mathrm{t}^{-1}\right]$ & $\begin{array}{r}6.6 \mathrm{E}+ \\
02\end{array}$ & $\begin{array}{r}7.8 \mathrm{E}+ \\
02\end{array}$ & $\begin{array}{r}6.6 \mathrm{E}+ \\
02\end{array}$ & $\begin{array}{r}8.1 \mathrm{E}+ \\
02\end{array}$ & $\begin{array}{r}7.9 \mathrm{E}+ \\
02\end{array}$ & $\begin{array}{r}6.4 \mathrm{E}+ \\
02\end{array}$ & $\begin{array}{r}6.1 \mathrm{E}+ \\
02\end{array}$ & $\begin{array}{r}6.1 \mathrm{E}+ \\
02\end{array}$ & $\begin{array}{r}7.4 \mathrm{E}+ \\
02\end{array}$ & $\begin{array}{r}5.2 \mathrm{E}+ \\
02\end{array}$ & $\begin{array}{r}6.5 \mathrm{E}+ \\
02\end{array}$ & $\begin{array}{r}7.2 \mathrm{E}+ \\
02\end{array}$ & $\begin{array}{r}6.2 \mathrm{E}+ \\
02\end{array}$ & $\begin{array}{r}6.7 \mathrm{E}+ \\
02\end{array}$ & $\begin{array}{r}6.2 \mathrm{E}+ \\
02\end{array}$ & $\begin{array}{r}5.9 \mathrm{E}+ \\
02\end{array}$ & $\begin{array}{r}6.1 \mathrm{E}+ \\
02\end{array}$ & $\begin{array}{r}7.3 \mathrm{E}+ \\
02\end{array}$ & $\begin{array}{r}7.3 \mathrm{E}+ \\
02\end{array}$ & $\begin{array}{r}5.7 \mathrm{E}+ \\
02\end{array}$ \\
\hline
\end{tabular}


103 Herein the results obtained for the economic assessment of Scenario I (CM), Scenario II (AD), and Scenario III (I) are

104 listed in Table G1. Note that $t_{c}$ stands for the tax deduction, $f$ for the fee paid to the company, $W M$ for the the waste

105 management of the wasted food, $S f$ for the cost of purchasing the surplus food, $C_{s f}$ for the total costs incurred by the

106 retailer excluding the purchase of the food products, and $C_{s f} *$ for the total costs incurred by the retailer including the

107 purchase of the food products.

108 Table G1: Costs calculated for each retail over the 13 months for Scenario I (CM), Scenario II (AD), and Scenario III (I). Please 109 note that the numbers were rounded to two significant digits.

\begin{tabular}{|c|c|c|c|c|c|c|c|c|c|c|c|c|c|c|c|}
\hline Retail & Scenario & $t_{c}\left[\epsilon \boldsymbol{t}^{1}\right]$ & $f\left[\epsilon t^{1}\right]$ & $\begin{array}{c}W M \\
{\left[\epsilon t^{1}\right]}\end{array}$ & $S f\left[\boldsymbol{E} \boldsymbol{t}^{-1}\right]$ & $C_{s f}\left[\epsilon \boldsymbol{t}^{1}\right]$ & $C_{s f}{ }^{*}\left[\epsilon t^{1}\right]$ & Retail & Scenario & $t_{c}\left[\epsilon t^{1}\right]$ & $f\left[\epsilon t^{1}\right]$ & $\begin{array}{c}W M \\
{\left[\epsilon t^{1}\right]}\end{array}$ & $S f\left[\epsilon t^{-1}\right]$ & $C_{s f}\left[\epsilon t^{-1}\right]$ & $C_{s f} *\left[\epsilon t^{1}\right]$ \\
\hline \multirow{3}{*}{1} & $\begin{array}{l}\text { Scenario I } \\
(\mathrm{CM})\end{array}$ & -680 & 240 & 20 & 1800 & -420 & 1300 & \multirow{3}{*}{2} & $\begin{array}{l}\text { Scenario I } \\
(\mathrm{CM})\end{array}$ & -580 & 200 & 26 & 1700 & -350 & 1400 \\
\hline & $\begin{array}{l}\text { Scenario } \\
\text { II (AD) }\end{array}$ & 0 & 0 & 57 & 1800 & 57 & 1800 & & $\begin{array}{l}\text { Scenario } \\
\text { II (AD) } \\
\end{array}$ & 0 & 0 & 57 & 1700 & 57 & 1800 \\
\hline & $\begin{array}{l}\text { Scenario } \\
\text { III (I) }\end{array}$ & 0 & 0 & 130 & 1800 & 130 & 1900 & & $\begin{array}{l}\text { Scenario } \\
\text { III (I) }\end{array}$ & 0 & 0 & 130 & 1700 & 130 & 1900 \\
\hline \multirow{3}{*}{3} & $\begin{array}{l}\text { Scenario I } \\
(\mathrm{CM})\end{array}$ & -610 & 210 & 24 & 1800 & -370 & 1400 & \multirow{3}{*}{4} & $\begin{array}{l}\text { Scenario I } \\
(\mathrm{CM})\end{array}$ & -620 & 220 & 25 & 1900 & -380 & 1500 \\
\hline & $\begin{array}{l}\text { Scenario } \\
\text { II (AD) }\end{array}$ & 0 & 0 & 57 & 1800 & 57 & 1800 & & \begin{tabular}{|l} 
Scenario \\
II (AD)
\end{tabular} & 0 & 0 & 57 & 1900 & 57 & 1900 \\
\hline & $\begin{array}{l}\text { Scenario } \\
\text { III (I) }\end{array}$ & 0 & 0 & 130 & 1800 & 130 & 1900 & & $\begin{array}{l}\text { Scenario } \\
\text { III (I) }\end{array}$ & 0 & 0 & 130 & 1900 & 130 & 2000 \\
\hline \multirow{3}{*}{5} & $\begin{array}{l}\text { Scenario I } \\
(\mathrm{CM})\end{array}$ & -360 & 130 & 38 & 1800 & -200 & 1600 & \multirow{3}{*}{6} & $\begin{array}{l}\text { Scenario I } \\
(\mathrm{CM})\end{array}$ & -510 & 180 & 31 & 1800 & -300 & 1500 \\
\hline & $\begin{array}{l}\text { Scenario } \\
\text { II (AD) }\end{array}$ & 0 & 0 & 57 & 1800 & 57 & 1900 & & $\begin{array}{l}\text { Scenario } \\
\text { II (AD) }\end{array}$ & 0 & 0 & 57 & 1800 & 57 & 1900 \\
\hline & $\begin{array}{l}\text { Scenario } \\
\text { III (I) }\end{array}$ & 0 & 0 & 130 & 1800 & 130 & 2000 & & $\begin{array}{l}\text { Scenario } \\
\text { III (I) }\end{array}$ & 0 & 0 & 130 & 1800 & 130 & 2000 \\
\hline \multirow{3}{*}{7} & $\begin{array}{l}\text { Scenario I } \\
(\mathrm{CM})\end{array}$ & -680 & 240 & 24 & 1900 & -410 & 1500 & \multirow{3}{*}{8} & $\begin{array}{l}\text { Scenario I } \\
(\mathrm{CM})\end{array}$ & -630 & 220 & 25 & 1800 & -380 & 1400 \\
\hline & $\begin{array}{l}\text { Scenario } \\
\text { II (AD) }\end{array}$ & 0 & 0 & 57 & 1900 & 57 & 2000 & & $\begin{array}{l}\text { Scenario } \\
\text { II (AD) }\end{array}$ & 0 & 0 & 57 & 1800 & 57 & 1900 \\
\hline & $\begin{array}{l}\text { Scenario } \\
\text { III (I) }\end{array}$ & 0 & 0 & 130 & 1900 & 130 & 2100 & & \begin{tabular}{|l|} 
Scenario \\
III (I) \\
\end{tabular} & 0 & 0 & 130 & 1800 & 130 & 2000 \\
\hline \multirow{3}{*}{9} & $\begin{array}{l}\text { Scenario I } \\
(\mathrm{CM})\end{array}$ & -600 & 210 & 27 & 1900 & -360 & 1500 & \multirow{3}{*}{10} & $\begin{array}{l}\text { Scenario I } \\
(\mathrm{CM})\end{array}$ & -650 & 230 & 30 & 2200 & -390 & 1800 \\
\hline & $\begin{array}{l}\text { Scenario } \\
\text { II (AD) }\end{array}$ & 0 & 0 & 57 & 1900 & 57 & 2000 & & $\begin{array}{l}\text { Scenario } \\
\text { II (AD) }\end{array}$ & 0 & 0 & 57 & 2200 & 57 & 2300 \\
\hline & $\begin{array}{l}\text { Scenario } \\
\text { III (I) }\end{array}$ & 0 & 0 & 130 & 1900 & 130 & 2000 & & $\begin{array}{l}\text { Scenario } \\
\text { III (I) }\end{array}$ & 0 & 0 & 130 & 2200 & 130 & 2400 \\
\hline \multirow{3}{*}{11} & $\begin{array}{l}\text { Scenario I } \\
(\mathrm{CM})\end{array}$ & -470 & 160 & 34 & 1900 & -270 & 1600 & \multirow{3}{*}{12} & $\begin{array}{l}\text { Scenario I } \\
(\mathrm{CM})\end{array}$ & -360 & 130 & 41 & 2100 & -190 & 1900 \\
\hline & $\begin{array}{l}\text { Scenario } \\
\text { II (AD) }\end{array}$ & 0 & 0 & 57 & 1900 & 57 & 1900 & & $\begin{array}{l}\text { Scenario } \\
\text { II (AD) }\end{array}$ & 0 & 0 & 57 & 2100 & 57 & 2100 \\
\hline & $\begin{array}{l}\text { Scenario } \\
\text { III (I) }\end{array}$ & 0 & 0 & 130 & 1900 & 130 & 2000 & & $\begin{array}{l}\text { Scenario } \\
\text { III (I) }\end{array}$ & 0 & 0 & 130 & 2100 & 130 & 2200 \\
\hline \multirow{3}{*}{13} & $\begin{array}{l}\text { Scenario I } \\
\text { (CM) }\end{array}$ & -130 & 47 & 48 & 1400 & -40 & 1400 & \multirow{3}{*}{14} & $\begin{array}{l}\text { Scenario I } \\
(\mathrm{CM})\end{array}$ & -430 & 47 & 37 & 2100 & -240 & 1800 \\
\hline & $\begin{array}{l}\text { Scenario } \\
\text { II (AD) }\end{array}$ & 0 & 0 & 57 & 1400 & 57 & 1400 & & $\begin{array}{l}\text { Scenario } \\
\text { II (AD) }\end{array}$ & 0 & 0 & 57 & 2100 & 57 & 2100 \\
\hline & $\begin{array}{l}\text { Scenario } \\
\text { III (I) }\end{array}$ & 0 & 0 & 130 & 1400 & 130 & 1500 & & $\begin{array}{l}\text { Scenario } \\
\text { III (I) }\end{array}$ & 0 & 0 & 130 & 2100 & 130 & 2200 \\
\hline \multirow{3}{*}{15} & $\begin{array}{l}\text { Scenario I } \\
(\mathrm{CM})\end{array}$ & -310 & 110 & 39 & 1600 & -160 & 1400 & \multirow{3}{*}{16} & $\begin{array}{l}\text { Scenario I } \\
(\mathrm{CM})\end{array}$ & -530 & 180 & 23 & 1500 & -320 & 1200 \\
\hline & $\begin{array}{l}\text { Scenario } \\
\text { II (AD) }\end{array}$ & 0 & 0 & 57 & 1600 & 57 & 1700 & & $\begin{array}{l}\text { Scenario } \\
\text { II (AD) }\end{array}$ & 0 & 0 & 57 & 1500 & 57 & 1500 \\
\hline & $\begin{array}{l}\text { Scenario } \\
\text { III (I) }\end{array}$ & 0 & 0 & 130 & 1600 & 130 & 1700 & & $\begin{array}{l}\text { Scenario } \\
\text { III (I) }\end{array}$ & 0 & 0 & 130 & 1500 & 130 & 1600 \\
\hline
\end{tabular}




\begin{tabular}{|c|c|c|c|c|c|c|c|c|c|c|c|c|c|c|c|}
\hline \multirow{3}{*}{17} & $\begin{array}{l}\text { Scenario I } \\
(\mathrm{CM})\end{array}$ & -520 & 180 & 30 & 1800 & -310 & 1500 & \multirow{3}{*}{18} & $\begin{array}{l}\text { Scenario I } \\
(\mathrm{CM})\end{array}$ & -580 & 200 & 30 & 2000 & -340 & 1700 \\
\hline & $\begin{array}{l}\text { Scenario } \\
\text { II (AD) }\end{array}$ & 0 & 0 & 57 & 1800 & 57 & 1900 & & $\begin{array}{l}\text { Scenario } \\
\text { II (AD) }\end{array}$ & 0 & 0 & 57 & 2000 & 57 & 2100 \\
\hline & $\begin{array}{l}\text { Scenario } \\
\text { III (I) }\end{array}$ & 0 & 0 & 130 & 1800 & 130 & 2000 & & $\begin{array}{l}\text { Scenario } \\
\text { III (I) }\end{array}$ & 0 & 0 & 130 & 2000 & 130 & 2200 \\
\hline \multirow{3}{*}{19} & $\begin{array}{l}\text { Scenario I } \\
(\mathrm{CM})\end{array}$ & -680 & 240 & 27 & 2100 & -410 & 1700 & \multirow{3}{*}{20} & $\begin{array}{l}\text { Scenario I } \\
(\mathrm{CM})\end{array}$ & -550 & 190 & 25 & 1600 & -330 & 1200 \\
\hline & $\begin{array}{l}\text { Scenario } \\
\text { II (AD) }\end{array}$ & 0 & 0 & 57 & 2100 & 57 & 2200 & & $\begin{array}{l}\text { Scenario } \\
\text { II (AD) }\end{array}$ & 0 & 0 & 57 & 1600 & 57 & 1600 \\
\hline & $\begin{array}{l}\text { Scenario } \\
\text { III (I) }\end{array}$ & 0 & 0 & 130 & 2100 & 130 & 2300 & & $\begin{array}{l}\text { Scenario } \\
\text { III (I) }\end{array}$ & 0 & 0 & 130 & 1600 & 130 & 1700 \\
\hline
\end{tabular}

110 
111 The contribution of each cost incurred by the retail in Scenario $I(C M)$ is summarised in Table G2.

112 Table $\mathrm{G}$ 2: Costs $\left[€ \mathrm{t}^{-1}\right]$ incurred by the retailer when managing the surplus food accordingly to the current management. Please 113 note that numbers were rounded to two significant digits.

\begin{tabular}{|c|c|c|c|c|}
\hline Retail & Tax credit $\left[€ \mathbf{t}^{-1}\right]$ & $\begin{array}{c}\text { Fee for } \\
\text { Company }\left[€ \mathbf{t}^{-1}\right]\end{array}$ & $\begin{array}{c}\text { Avoided Waste } \\
\text { Management }\left[€ \mathrm{t}^{-1}\right]\end{array}$ & $\begin{array}{c}\text { Waste } \\
\text { Management }\left[€ \mathrm{t}^{-1}\right]\end{array}$ \\
\hline 1 & -4700 & 1600 & -270 & 140 \\
\hline 2 & -2800 & 980 & -150 & 120 \\
\hline 3 & -8800 & 2900 & -490 & 360 \\
\hline 4 & -4400 & 1500 & -250 & 210 \\
\hline 5 & -2200 & 770 & -110 & 210 \\
\hline 6 & -3400 & 1200 & -180 & 220 \\
\hline 7 & -3600 & 1300 & -210 & 160 \\
\hline 8 & -7700 & 2600 & -420 & 340 \\
\hline 9 & -3700 & 1300 & -180 & 160 \\
\hline 10 & -3600 & 1300 & -180 & 180 \\
\hline 11 & -2900 & 1000 & -170 & 240 \\
\hline 12 & -2700 & 920 & -120 & 290 \\
\hline 13 & -900 & 310 & -56 & 290 \\
\hline 14 & -3400 & 1200 & -170 & 320 \\
\hline 15 & -5200 & 1700 & -360 & 750 \\
\hline 16 & -5100 & 1800 & -380 & 260 \\
\hline 17 & -3600 & 1200 & -200 & 180 \\
\hline 18 & -4400 & 1500 & -230 & 230 \\
\hline 19 & -5500 & 1900 & -220 & 200 \\
\hline 20 & -5700 & 2000 & -260 & 290 \\
\hline
\end{tabular}

114 


\section{Appendix H}

Herein the European laws regulating food redistribution are discussed. The main barriers and possible ways

117 to overcome their limitations are also presented.The laws concerning and influencing food donations are the following:

118 (i) the General Food Law; (ii) the Food Hygiene Package; (iii) Food Labelling and Durability; (iv) the VAT Directive; and (v) the Waste Framework Directive (WFD) (Deloitte 2014). These are discussed below together with their key barriers and the solutions proposed by the Member States to overcome their limitations.

The General Food Law (Regulation (EC) No 178/2002) provides guidelines to assure a coherent approach when developing food legislations at national level (Deloitte, 2014). All food business operators have to comply with this regulation, including charities and redistribution organisations (European Commission, 2017). The law concerns responsibility, liability, traceability, and food hygiene and safety. The latter are intended to ensure the safety of food products for consumers. Nevertheless, the requirements of food safety and hygiene should not be exceeded, otherwise 127 the risk of generating more food waste could arise (European Union, 2016). Regarding responsibility, all food business operators are responsible for the hygiene of the food at the stage of the FSC under their responsibility (Deloitte, 2014). In respect to traceability, food business operators have to ensure that consumers are protected against any risk and, hence, have to implement a traceability system at their stage of the FSC (European Commission, 2017). Finally,

131 liability concerns that food business operators are liable with damage if a product is defective (Deloitte, 2014). 132 Liability is one of the main barriers in respect to food donations (De Pieri et al., 2017). Indeed, in case of food 133 poisoning, food producers and retailers would compromise their reputation (Deloitte, 2014). To overcome these 134 problems, several solutions have been applied at national level across Member States. For instance, the Good 135 Samaritan legislation was approved in Italy, recognising food charities as the final consumers and hence avoiding that 136 people could sue food donors (Deloitte, 2014). The Good Samaritan legislation is a clear example of policy that 137 encourages retailers to prefer redistribution to options that are lower in the hierarchy. This highly affects their environmental performance, as supported by this study. 
143 Union, 2016). Furthermore, these legislations were transported into stricter regulations at national level (Deloitte, 144 2014). To overcome these problems, the European Commission decided to simplify the regulations without 145 jeopardizing food safety (Deloitte, 2014). Hence, if this law is perceived as too strict, retailers would be discouraged 146 to donate food, even if this could lead to a significant reduction in emissions compared to recovering energy from 147 food waste. to consumers to ensure their protection and health, but also to allow them to make aware choices and safe use of food (European Commission, 2017). Food manufacturers have to establish whether to label a food product with a "use by" or a "best before" date (European Commission, 2017). "Use by" dates are applied to food products that are no longer safe to eat from a microbiological standpoint and pose a danger to human health (Deloitte, 2014; European Commission, 2017). On the other hand, "best before" dates are used for food products that are still safe to eat and only present flaws in the quality (e.g. appearance) (Deloitte, 2014; European Commission, 2017). Therefore, "use by" dates are related to food safety, whilst "best before" dates to food quality (European Commission, 2017). Across the European Union there is a general confusion in regards to "best before" dates and it is thought that food products that have exceeded it cannot be donated (Deloitte, 2014). To overcome this problem, Belgium, for instance, provided guidelines on how to assess the additional lifetime of food products that have reached their "best before" date (Deloitte, 20214). This, along with initiatives such as the Samaritan law, may ultimately encourage redistribution of surplus food over less environmentally and socially sound management options. to be implemented at national level (European Commission, 2017). The directive states that food donations are taxable if they are made by a taxable person and whether the VAT on the purchase of the goods is entirely or partially deductible (Deloitte, 2014). Further, the taxable amount is calculated as the purchase price at the moment of the donation corrected by the state of the goods at the time of the donation (European Commission, 2017). However, food donors are not subject to VAT if the food donated is close to its expiration date, as the value of the food products is considered as low or close to zero (when donated), thus having negative effects for food donations (Deloitte, 2014; tax credits, or corporate tax incentives (European Commission, 2017). The latter was implemented in France and the 
170 results obtained in this study for the cost analysis on Scenario $I(C M)$ show that such an incentive can boost the amount 171 of surplus food donated as the retailers would generate income from donations.

172 The Waste Framework Directive (Directive 2008/98/EC) establishes that the first stage of the waste hierarchy

173 is prevention, and that Member States have to implement prevention programs (European Commission, 2017).

174 However, the directive neither specifies how the hierarchy should be applied to the food waste case nor gives a 175 common definition of what food waste is (European Union, 2016). On top of these barriers, many of the Member 176 States have implemented fiscal incentives at the lower stages of the hierarchy (e.g. for anaerobic digestion), de facto 177 preventing or making less economically attractive food redistribution (Deloitte, 2014). 

2-0 LCA Consultants (2007). LCA Food Database. Available at http://gefionau.dk/lcafood/. Accessed on June 2016. Agence française de sécurité sanitarie des aliments (2007). "Consommations Alimentaires 2 (Inca 2)". Available at https://www.anses.fr/fr/content/inca-2-les-résultats-dune-grande-étude.

Camera di Commercio Industria Artigianato e Agricoltura di Roma (2015). "Prezzi Medi Mensili all’ingrosso Praticati sulla Piazza di Roma.” Available at https://www.rm.camcom.it/pagina1148_listino-prezzi-allingrosso.html.

ChefSteps (2017). Accessed on 9/05/2017. Availabla at https://www.chefsteps.com/activities/croissant-dough.

185 Clavreul, J., Baumeister, H., Christensen, T.H., \& Damgaard, A. (2014). An environmental assessment system for 186 environmental technologies. Environmental Modelling and Software, 60, 18-30. doi: 10.1016/j.envsoft.2014.06.007

187 De Pieri, B., Tallarico, T., \& Baglioni, S. (2017). European Policy for Food Security: The Surplus Food Redistribution 188 Option.” In Foodsaving in Europe, 13-35. Palgrave Macmillan, Cham. https://doi.org/10.1007/978-3-319-56555-2

189 Deloitte (2014). "Comparative Study on EU Member States. Legislation and Practices on Food Donation. " Available 190 at https://www.eesc.europa.eu/resources/docs/executive-summary_comparative-study-on-eu-member-states191 legislation-and-practices-on-food-donation.pdf.

192 Doublet, G., Jungblkuth, N., Stucky, M., \& Schori, S. (2013). Harmonised environmental sustainability in the 193 European food and drink products. SENSE project: ESU-services Ltd. Available at http://esu194 services.ch/fileadmin/download/doublet-2013-SENSE_Deliverable-2_1-LCAorangejuice.pdf

195 European Commission (2017). "Official Journal of the European Unio, C361.” Vol. 60. Available at https://eur196 lex.europa.eu/legal-content/EN/TXT/?uri=OJ\%3AC\%3A2017\%3A361\%3AFULL.

197 European Union (2016). "Combating Food Waste: An Opportunity for the EU to Improve the Resource-Efficiency of 198 the Food Supply Chain. Special Report No. 34 (EN). European Court of Auditors (ECA) - European Union.” 199 https://doi.org/10.2865/8374

200 France AgriMer (2014). "Consommation Des Produits Carnés En 2014." 201 http://www.franceagrimer.fr/content/download/40104/372599/file/STA-VIA-CONSO 2014-aout2015.pdf

202 Halaal Recipes (2017). Butter biscuits. Available at https://halaal.recipes/recipes/details/3830/butter-biscuits 
Interfel (2018). Les fruits et légumes frais. Available at https://www.lesfruitsetlegumesfrais.com/ (accessed March 2018)

205 Les Fabricants de Biscuits \& Gâteaux de France (2016). Chiffres-Clés 2015. Available at 206 http://www.alliance7.com/wp-content/uploads/2016/07/chiffres-clés-biscuits-gâteaux-2015.pdf.

207 Lillywhite, R., Sarrouy, C., Davidson, J., May, D., \& Plackett, C. (2013). Energy dependency and food chain security 208 FO0415. The University of Warwick. Available at sciencesearch.defra.gov.uk.

209 Lo Giudice, A., \& Clasadonte, M.T. (2014). LCI Preliminary results of in the Sicilian durum wheat pasta chain 210 production. Journal Commodity Science Technology Quality 2011, 50 (I), 65-79.

211 Maison du Lait (2018). La filière laitière française en chiffres. http://www.filiere-laitiere.fr/fr/chiffres-cles/filiere212 laitiere-francaise-en-chiffres

213 Masanet, E., Therkelsen, P., \& Worrell, E. (2012). Energy Efficiency Improvement and Cost Saving Opportunities 214 for the Baking Industry. An ENERGY STAR Guide for Plant and Energy Managers. Lawrence Berkeley National 215 Laboratory. Available at https://eetd.lbl.gov/sites/all/files/baking_guide_final_28dec2012c.pdf

216 Ministère de l'agriculture, \& France AgriMer (2016). Construction de l'observatoire de La Formation Des Prix et Des 217 Marges $\quad$ Des $\quad$ Produits Alimentaires. Available 218 agriculture.gouv.fr/telecharger/78959?token=9c711ac06ab931cce257e6b59d37f116.

219 Paul Holliwood (2017). Danish Pastry Dough. Accessed on 9/05/2017. Available at 220 http://paulhollywood.com/recipes/danish-pastry-dough/

221 Rosa, D., Figueiredo, F., Castanheira, E. G., \& Freire, F. (2016). Life-cycle assessment of fresh and frozen chestnut. 222 Journal of Cleaner Production 140 (2017), 742-752.

223 Shamshirband, S., Khoshnevisan, B., Yousefi, M., Bolandnazar, E., Anuar, N.B., Wahab, A.W.A. \& Khan, S.U.R. 224 (2015). A multi-objective evolutionary algorithm for energy management of agricultural systems — a case study in 225 Iran. Renewable and Sustainable Energy Reviews, 44, pp.457-465.

226 Wernet, G., Bauer, C., Steubing, B., Reinhard, J., Moreno-Ruiz, E., \& Weidema, B. (2016). The ecoinvent database 227 version 3 (part I): overview and methodology. The International Journal of Life Cycle Assessment, [online] 21(9), 228 pp.1218-1230. Available at: <http://link.springer.com/10.1007/s11367-016-1087-8> Accessed in May 2017 